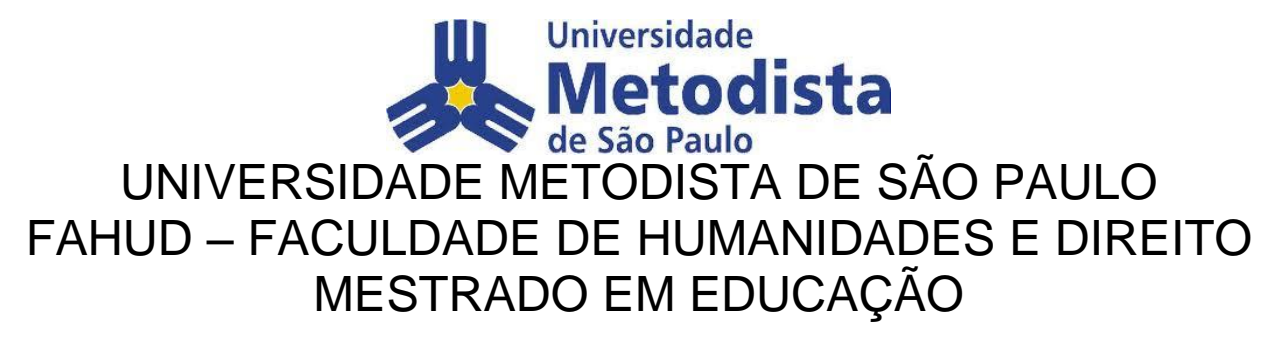

TATIANE DE FÁTIMA WANZELER MEIRELES

\title{
O DESAFIO DO PEDAGOGO NOS ESPAÇOS DE EDUCAÇÃO NÃO FORMAL
}

São Bernardo do Campo 
TATIANE DE FÁTIMA WANZELER MEIRELES

\section{O DESAFIO DO PEDAGOGO NOS ESPAÇOS DE EDUCAÇÃO NÃO FORMAL}

Dissertação apresentada ao Programa de Pós-Graduação em Educação (Mestrado) da Faculdade de Humanidades e Direito, na Universidade Metodista de São Paulo, sob a orientação da Prof ${ }^{a}$. Dr ${ }^{\mathrm{a}}$. Marília Claret Geraes Duran, para obtenção do título de Mestre em Educação.

São Bernardo do Campo 


\section{FICHA CATALOGRÁFICA}

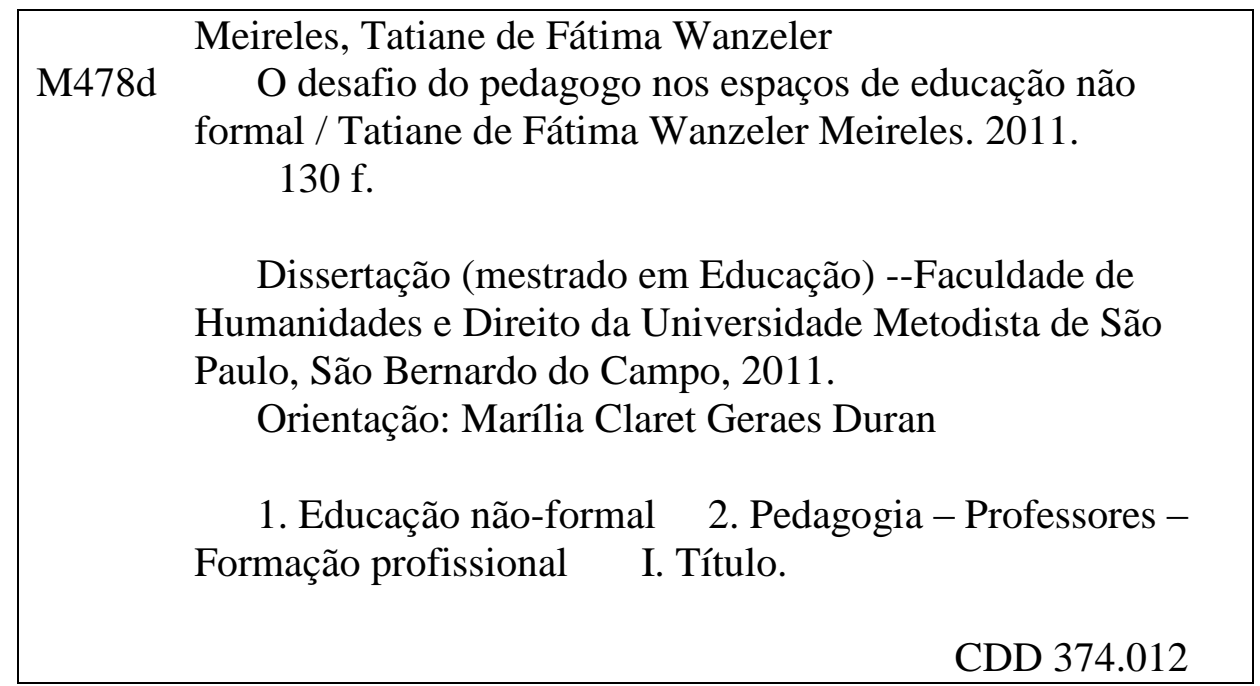


A dissertação de mestrado sob o título " O desafio do pedagogo nos espaços de educação não formal", elaborada por Tatiane de Fátima Wanzeler Meireles foi apresentada e aprovada em 20 de março de 2012, perante banca examinadora composta por $\operatorname{Prof}^{\mathrm{a}} \mathrm{Dr}^{\mathrm{a}}$ Marília Claret Geraes Duran (Presidente/UMESP), $\operatorname{Prof}^{\underline{a}} \operatorname{Dr}^{\mathrm{a}}$ Lúcia Pintor Santiso Villas Boas (Titular/UMESP) e Profo Drº Antônio Chizzotti(Titular/ PUC/SP).

Prof ${ }^{a}$. Dr . Marília Claret Geraes Duran

Orientadora e Presidente da Banca Examinadora

Prof $^{a}$. Dr ${ }^{a}$. Roseli Fischmnan

Coordenadora do Programa de Pós-Graduação

Programa: Pós - Graduação Mestrado em Educação

Área de Concentração: Educação

Linha de Pesquisa: Formação de Professores 


\section{AGRADECIMENTOS}

Aos meus pais, Meireles e Natalina pelo grande ensinamento e incentivo de que é possível atingir nossos sonhos se lutarmos por eles.

Aos meus irmãos Fernanda e Fernando pelo grande incentivo e com quem sempre compartilho minhas conquistas.

Ao meu amor Márcio pela força e incentivo em todas as minhas escolhas e decisões.

À Amiga, Professora e Orientadora Marília Claret Geraes Duran, que contribuiu com todo o seu conhecimento, amizade e paciência em cada momento do meu crescimento acadêmico.

A todos os participantes da pesquisa e a todos que direta ou indiretamente contribuíram com a construção deste trabalho. 


\section{EPÍGRAFE}

"Ninguém escapa da educação. Em casa, na rua, na igreja ou na escola, de um modo ou de muitos todos nós envolvemos pedaços da vida com ela: para aprender, para ensinar, para aprender e ensinar. Para saber, para fazer, para ser ou para conviver, todos os dias misturamos a vida com a educação. Com uma ou com várias: educação? Educações".

(Carlos Rodrigues Brandão) 


\section{SUMÁRIO}

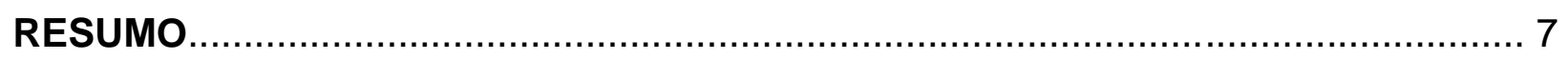

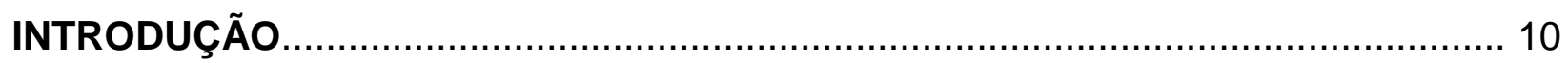

MEMORIAL FORMATIVO E PROFISSIONAL.................................................... 10

CAPÍTULO 1 - BREVE HISTÓRICO DA EDUCAÇÃO NÃO FORMAL......................... 19

1.10 surgimento da Educação não formal no Brasil................................................. 19

$1.2 \mathrm{~A}$ atuação do pedagogo no campo da educação não formal.................................. 26

$1.3 \mathrm{O}$ que diz a Legislação sobre a educação não formal............................................. 32

CAPÍTULO 2 - CONCEPÇÕES SOBRE EDUCAÇÃO NÃO FORMAL ....................... 42

2.1 A educação não formal na perspectiva de Libâneo.............................................. 42

2.2 A educação não formal na perspectiva de Gohn................................................ 46

2.3 A educação não formal na perspectiva de Afonso............................................. 51

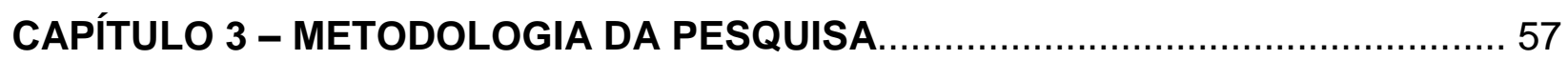

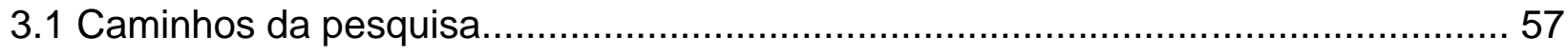

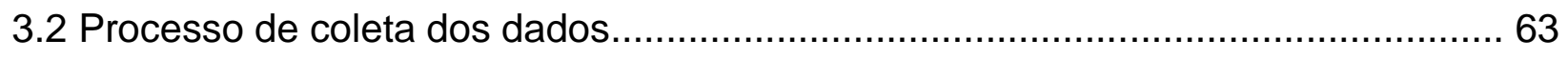

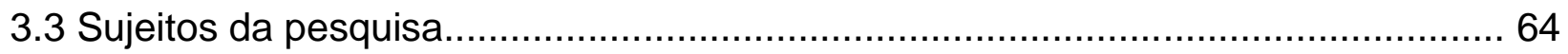

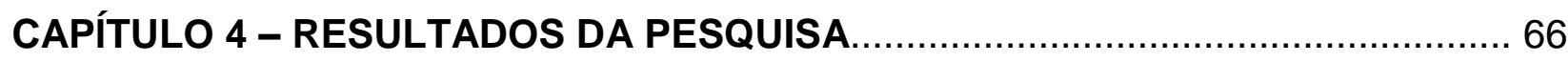

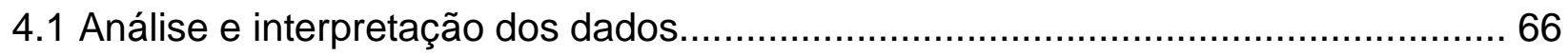

4.2 Resultado das entrevistas com os pedagogos................................................. 84

4.3 Resultado das entrevistas com o gestor de projetos da instituição.......................... 86

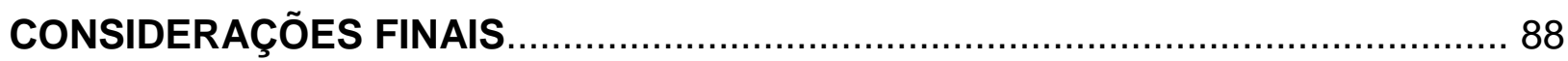

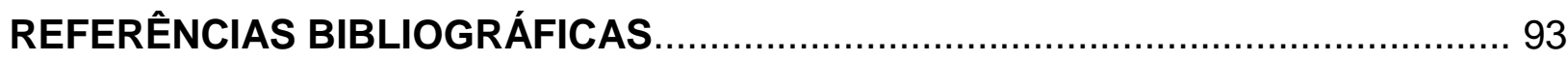

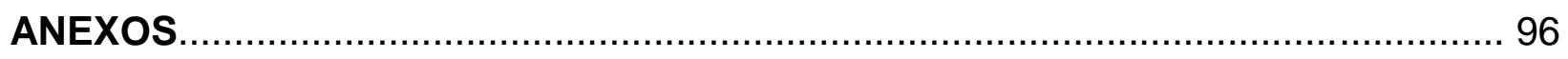

ANEXO 1 ROTEIRO DE ENTREVISTA PEDAGOGOS ........................................ 97 
ANEXO 2 ROTEIRO DE ENTREVISTAS GESTOR DE PROJETOS......................... 101

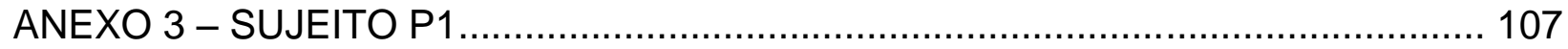

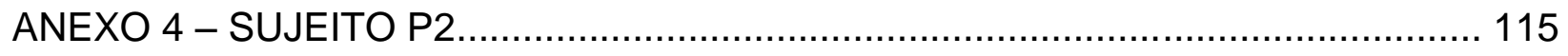

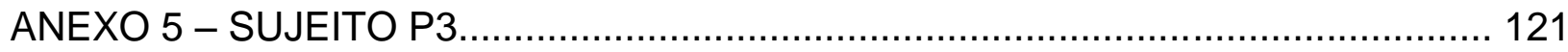

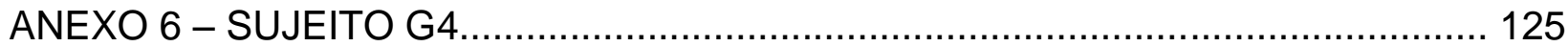




\section{RESUMO}

A pesquisa teve como foco analisar e problematizar aspectos relevantes que envolvem a trajetória formativa e o processo de conquista e abrangência da atuação do pedagogo a partir de sua inserção em espaços de educação não formal, pois com o advento da globalização, surge à constatação na sociedade atual da importância e da necessidade da educação não formal. Nesse processo, é possível reconhecer que a educação não é um processo exclusivo da escola, ela pode acontecer em locais diferentes e em diversas situações sociais que não corresponde ao modelo escolar formal. Nesta perspectiva, busca-se superar a compreensão da educação somente como prática formal e ampliar seu sentido, reconhecendo não só a importância, mas a necessidade das práticas educativas que acontecem para além da escola. A pesquisa de cunho qualitativo compreende um trabalho bibliográfico intenso, no que se refere à construção e à conquista de espaços dos pedagogos no campo da educação não formal no Brasil. Assim, a pesquisa tem como suporte teórico alguns autores que problematizam questões relacionadas à educação não-formal: Afonso, 2002; Libâneo, 2001; Gadotti, 2005; Gohn, 2008; Duran \& Santos Neto (2007). Foram realizadas entrevistas semiestruturadas com o total de 04 sujeitos, sendo 03 pedagogos que trabalham numa ONG (Organização Não-Governamental) que tem como foco o trabalho com Projetos Sociais e 01 coordenadora de projetos da própria instituição, de forma a compor um perfil desses profissionais inseridos em tal contexto. Considerando dados da investigação é possível dizer que a educação não formal é uma modalidade de educação que vem se ampliando muito na sociedade atual. Por outro lado, apesar dessa ampliação, a sua compreensão ainda é de difícil entendimento porque não há uma legislação específica que the dê sustentação, o que abre precedentes para algumas considerações do que se denomina modalidade de educação não formal. $O$ aprofundamento da análise dos dados da pesquisa possibilitou chegar a considerações mais precisas do campo da educação não formal, além de trazer elementos para compreensão de sua importância nesse diversificado universo de atuação.

Palavras chaves: Trajetória formativa, Atuação do pedagogo, Educação não formal 


\section{ABSTRACT}

The research focused on analyze and discuss relevant issues involving the trajectory and the formative process of conquest and scope of work of teachers from their insertion in spaces of non-formal education, because with the advent of globalization, there is the realization in society current importance and necessity of non-formal education. In this process, it is possible to recognize that education is not an exclusive school, it can happen in different places and in different social situations that do not correspond to the model school formal. In this perspective, we seek to overcome the understanding of education only as formal practice and expand your sense, recognizing not only the importance but the necessity of educational practices that take place beyond the school. The qualitative research comprises an intensive literature review, regarding the construction and acquisition of areas of educators in the field of non-formal education in Brazil. The research is supported by some authors that question theoretical issues related to non-formal education: Afonso, 2002; Libâneo, 2001; Gadotti, 2005; Gohn, 2008; Duran \& Santos Neto (2007). Were conducted semi-structured interviews with a total of 04 subjects, 03 teachers working in an NGO (nongovernmental organization) that focuses on working with social projects and 01 project coordinator of the institution, in order to compose a profile those health professionals involved in such a context. Whereas research data is possible to say that non-formal education is a form of education which has been growing a lot in today's society. On the other hand, despite this expansion, their understanding is still difficult to understand because there is no specific legislation that will give you support, which opens up precedents for some considerations of what is called non-formal mode of education. Further analyses of survey data enabled them to more detailed considerations of the field of non-formal education, and provide elements for understanding of their importance in this diverse of action.

Keywords: Trajectory formation, Role of the teacher, Non-formal education 


\section{LISTA DE ABREVIATURAS E SIGLAS}

ONG - Organização Não Governamental

OSCIPS - Organização da Sociedade Civil de Interesse Público

CNAS - Conselho Nacional de Assistência Social

CEBAS - Certificado de Entidade Beneficente de Assistência Social 


\section{INTRODUÇÃO}

"A educação é um processo social, é desenvolvimento. Não é a preparação para a vida, é a própria vida" (John Dewey).

\section{MEMORIAL FORMATIVO E PROFISSIONAL}

A trajetória formativa de cada profissional da educação não se constitui apenas a partir da articulação entre os diversos saberes da sua formação específica, mas entre as diferentes experiências de vida e as diferentes experiências profissionais vividas nos diversificados universos educacionais.

Assim, baseada na articulação dos diversos saberes e experiências, apresentar o meu memorial formativo e profissional é um ponto chave para entender não só como se deu o processo de me tornar quem sou hoje. É uma forma de entender também como se deu a minha escolha em pesquisar sobre a atuação do pedagogo nos espaços de educação não-formal.

Venho de uma família simples e humilde do interior do Pará, meu pai filho de lavrador e de uma professora de magistério, junto com minha mãe costureira, filha também de lavradores, mudaram-se para Belém do Pará capital no ano 1975. Neste ano meu pai viu a oportunidade de melhorar de vida se inscrevendo na época no Processo seletivo do CIABA, escola para a formação de Oficiais da Marinha Mercante.

$\mathrm{Na}$ época, não tinha muitas expectativas de que fosse selecionado, pois além da concorrência, trabalhava incansavelmente na venda de artigos artesanais. Esses artigos eram bolsas feitas a partir da fibra do tururi (uma fibra natural vegetal que envolve os frutos de uma palmeira chamada ubuçu muito utilizada na confecção de 
artesanatos e utilitários de moda) produzidos por minha mãe que estava grávida da minha irmã, filha mais velha.

Apesar de todas as dificuldades enfrentadas por eles, meu pai consegue ser aprovado na chamada repescagem do concurso, fato esse que iria mudar profundamente nossas vidas. Mas isso é só começo de tudo, pois apesar do meu pai estar cursando o CIABA, as dificuldades continuaram, pois ele já não tinha mais tanto tempo disponível para ajudar minha mãe na venda dos artesanatos.

Com o meu nascimento em 1976, meu pai continua fazendo o CIABA e minha mãe costurando para ajudar no sustento da casa. Já em 1978 com o nascimento do meu irmão, meu pai consegue enfim terminar o período de escola da marinha mercante e se prepara para dar sua primeira viagem já como oficial da marinha.

E foi assim, graças à formação do meu pai e ao incentivo, luta e companheirismo da minha mãe, que vimos à situação de nossa família mudar em todos os sentidos. Então em 1980, em virtude da localização do emprego do meu pai mudamos para Santos - São Paulo, onde moramos por um período de oito anos, fase em que cursei a educação infantil.

Em 1988, minha família decide mudar novamente para a nossa terra natal, Belém do Pará, porém, não para a capital, mas para uma cidade do interior onde moravam meus avôs por parte de pai. Nessa época, eu e meus irmãos enfrentamos um período de transição difícil, pois crescemos envolvidos em uma região diferente, num ritmo diferente e numa cultura muito diferente da nossa.

Assim, a fase de adaptação foi complexa, apesar das iniciativas de meu pai em tentar nos proporcionar sempre o melhor. Ainda nesse ano, dei continuidade em meus estudos, iniciei a $6^{\underline{a}}$ série do ensino fundamental na Escola Estadual de $1^{\circ}$ e $2^{\circ}$ Grau Almirante Barroso.

Passada essa fase, pude com maior tranquilidade levar meus estudos adiante. Porém em 1991, minha família resolve mudar-se novamente, desta vez para a capital paraense, Belém do Pará, em virtude, mais uma vez, do emprego de meu pai e também 
dos nossos estudos, já que eu e minha irmã iríamos iniciar o ensino médio, antigo $2^{\circ}$ grau.

Essa fase foi muito importante, pois a cada dia as responsabilidades com os estudos aumentavam e a vontade em fazer vestibular para medicina também. Hoje, tenho certeza que por influência e convivência com minha irmã, já que a mesma sonhava em ser médica desde pequena.

Terminado o ensino médio em 1993, prestamos vestibular eu e minha irmã para medicina e não fomos aprovadas, somente no ano seguinte, em 1994 ao tentar vestibular novamente para medicina foi que minha irmã foi aprovada e eu não. Considero esse período, um dos mais difíceis em minha trajetória formativa, mas essencial para o meu crescimento pessoal e até mesmo para o meu amadurecimento intelectual.

Nos anos seguintes continuei prestando vestibular, porém, não mais para medicina, mas para outros cursos relacionados à área da saúde, mas também sem sucesso de aprovação. Assim, os anos passavam e eu me sentia perdida, pois não tinha certeza do que queria fazer, só tinha a certeza de que não mais queria ser médica e isso já era um importante passo no processo de me tornar quem sou hoje.

No ano de 1999, surgiu a oportunidade de fazer o concurso do antigo CEFET, agora Instituto Federal de Educação Ciência e Tecnologia do Pará (IFPA) e acabei optando por fazer o curso de Saúde Pública, que cursei durante dois anos. Durante esse tempo, tive o privilégio de conhecer e conviver com vários professores e essa convivência foi despertando a vontade de também fazer um curso superior para trabalhar na área da educação.

Assim, no final do ano de 2001, agora certa do que realmente queria, decidi fazer vestibular para Pedagogia na Universidade da Amazônia. O período da graduação foi extremamente bom, pois tive a oportunidade de me aproximar das diversas teorias e autores da educação e também de conhecer pessoas e profissionais que já tinham 
alguma experiência na área. Enfim, foi um momento em que pude mergulhar realmente no universo educativo e me senti parte dele.

No último ano de graduação, em 2005, já trabalhando numa escola de educação infantil, tive a oportunidade de cursar uma disciplina eletiva denominada Educação e Empresas, que além de proporcionar novos conhecimentos me despertou para um amplo e diversificado mercado de trabalho que é o espaço da educação não formal.

A partir desse momento, comecei a ter certeza de que precisava de novos desafios, então aprofundei leituras na área em questão e conversei com algumas pessoas sobre minha vontade de atuar além dos limites escolares. Porém, sabia que, além da vontade, precisava me preparar, isto é, precisava primeiramente fazer uma pós-graduação que me ampliasse os conhecimentos a respeito da educação não formal. Então, minha preocupação foi pesquisar uma pós-graduação que me desse o conhecimento teórico, já que o conhecimento prático eu só teria quando mergulhasse de fato no universo da educação não formal.

Assim, graduei-me em Pedagogia, Ciência da Educação, no final de 2005 pela Universidade da Amazônia e, no início do ano de 2006, com o incentivo de alguns professores da graduação e com o apoio da minha família, decidi mudar-me para São Paulo para fazer um curso de pós-graduação em Pedagogia Empresarial.

Nesse contexto, pude ter um contato mais próximo com professores e com profissionais que já tinham alguma experiência de trabalho na área da educação não formal e isso estimulou cada vez mais o meu desejo de também poder atuar nessa área.

Dessa forma, por incentivo de uma amiga da pós-graduação de Pedagogia Empresarial, no segundo semestre resolvi iniciar outra pós-graduação, MBA Gestão Estratégia do Terceiro Setor, ou seja, uma pós ainda mais direcionada ao universo de educação que eu tanto almejava. 
Então, durante dois anos me dediquei quase que exclusivamente nessa trajetória de educação continuada. Foi um período de aprendizagens e amizades significativas que fortaleceram ainda mais minha vontade de colocar em prática todo 0 conhecimento que as pós-graduações haviam me proporcionado.

Após esse período, iniciei um processo incansável em busca de uma oportunidade de trabalho na área do Terceiro Setor. No ano de 2008, comecei a trabalhar numa Fundação de cunho social e educacional que fazia parte de uma Universidade, mais especificamente na área de Projetos Sociais.

Ou seja, era um espaço de educação formal que se dedicava também a desenvolver atividades na área da educação não formal e tinha como missão promover a melhoria da qualidade de vida da população socialmente excluída, a partir de uma educação de qualidade. Seu principal foco era o desenvolvimento de projetos de geração de emprego e renda, de qualificação e requalificação profissional e a promoção do desenvolvimento local de forma integrada e sustentável.

Do ponto de vista da prática, essa experiência era tudo que eu precisava, para entender mais sobre esse universo, especialmente porque como eu fazia parte da equipe da Coordenação Pedagógica dos Projetos, pude vivenciar cada etapa do mesmo. Isto é, desde a sua elaboração até a fase de seu funcionamento na prática.

Com o passar do tempo, algumas inquietações foram surgindo. Comecei a observar entre outros fatores, o despreparo dos instrutores que capacitávamos e que ministravam as aulas dos diversos cursos. Então a vontade de continuar estudando para dar uma melhor formação aos mesmos e a vontade também de ter uma melhor valorização profissional no mercado de trabalho fizeram com que eu decidisse fazer mestrado.

Nesse contexto, mergulhada no universo da educação não formal, também estimulada pela minha Coordenadora e amiga que estava terminando seu Doutorado em Educação, comecei a pesquisar e me inscrever em alguns processos seletivos para Mestrado na área da Educação, porém, sem sucesso de aprovação. 
Em meados de julho de 2009, orientada por essa mesma amiga, me inscrevi no Processo Seletivo de Mestrado em Educação da Universidade Metodista de São Paulo para cursar uma disciplina como aluna em regime especial. Hoje, sei que foi a melhor escolha que poderia ter feito, pois esse tempo como aluna especial foi fundamental para conhecer mais de perto o contexto que permeia esse universo, assim como amadurecer a idéia inicial do meu projeto de pesquisa.

Depois de algum tempo, cursando em regime especial de mestrado a disciplina Formação de Professores e Profissão Docente, tive a oportunidade de ter um contato mais próximo com a professora que ministrava essa disciplina, a ilustre Professora Dra Marília Claret Geraes Duran. Então, pude expor minha idéia e meu pré projeto de pesquisa, para então, posteriormente fazer o processo seletivo para cursar o mestrado como aluna regular.

Foi então com muitas expectativas que no final do ano de 2009, fiz o processo seletivo para o Mestrado em Educação 2010 como aluna regular, sendo aprovada pela Universidade Metodista de São Paulo tendo como orientadora a Prof. Drª Marília Claret Geraes Duran.

Assim, a escolha do tema da pesquisa se deve em parte a minha vivência, ou seja, às minhas inquietações enquanto profissional no campo da educação não formal, mas se deve também ao que não vivenciei, mas pude observar no percurso da minha trajetória formativa.

Foram muitos os amigos que ficaram à beira do caminho, à margem da escola e da própria sociedade por não ter estudos, outros mesmo não tendo frequentado a escola formal conseguiram êxito profissional. Enfim, talvez tudo isso tenha contribuído para despertar em mim esse olhar para a janela da escola, para a importância do ensino formal e, depois, para a educação não formal como complemento do ensino formal.

Passei e continuo passando pelos bancos da educação formal e sei da sua fundamental importância para a minha vida profissional, só que hoje enquanto 
profissional da educação e em virtude da busca constante por novas experiências no campo escolar me deparo com um universo rico de educações que não deve substituir, é claro, o ensino formal, mas que deve, e pode caminhar paralelamente a ele.

Hoje olhando para trás, sei que tive a oportunidade que muitos não tiveram ou não têm, ou seja, de freqüentar a escola formal, mas sei que quem não teve a mesma oportunidade ou vivência que eu também tive, pode experimentar outras experiências. Ou seja, outros ensinamentos que também são válidos e fundamentais nos mais diversos âmbitos da vida.

Neste sentido, a possibilidade de pesquisar a referida temática é uma oportunidade não só de estreitar a discussão com a Universidade, mas a possibilidade de também refletir que se aprende, sim, fora da escola e que esse aprendizado é importante. Reconhecer que há outras formas de aprender é valorizar o conhecimento daqueles que mesmo não passando pelos bancos da escola (ensino formal) adquiriram grandes conhecimentos teóricos ou práticos enquanto ser humano e como profissional.

Assim, dando continuidade a minha trajetória formativa, devo dizer que a minha escolha em fazer mestrado em educação é mais uma forma de ampliar meus conhecimentos, adquirir novas competências didáticas com 0 intuito de mediar processos de ensino que realmente potencializem a aprendizagem e possam contribuir para a formação de outros profissionais.

Entendo que independente da área de atuação, seja no campo da educação formal ou no campo da educação não formal, o profissional da educação deve estar em constante atualização e busca já que a educação ou as "educações" nascem de um processo de confronto permanente entre o indivíduo e o meio numa construção permanente daquilo que pensamos sobre o mundo, do que vemos, vivemos, sentimos e desejamos.

Numa perspectiva de análise e construção de conhecimentos acerca da atuação dos profissionais de pedagogia nos espaços de educação não formal fez-se necessário dividir este trabalho nos seguintes capítulos, de maneira a tornar claro o caminho que será percorrido durante o estudo a ser realizado. 
O CAPÍTULO 1 - BREVE HISTÓRICO DA EDUCAÇÃO NÃO FORMAL - esse capítulo está subdividido, em três partes: na primeira, faço uma abordagem mais histórica da Educação não formal com a finalidade de compreender como se deu o surgimento da Educação não formal no Brasil. Na segunda parte, faço uma discussão sobre a inserção e atuação dos pedagogos nos mais diferentes segmentos e áreas da sociedade com o objetivo de entender com mais profundidade como se deu a dinâmica da construção e da conquista de espaço do pedagogo no campo da educação não formal. Na terceira parte, faço algumas considerações sobre a educação não formal, considerando-a enquanto processo de uma prática social constituída e constituinte das relações sociais mais amplas. Nesse contexto evidencio sua especificidade, considerando que a Educação Não Formal vem sendo interpretada pela Lei de Diretrizes e Bases da Educação Nacional - LDB 9394/96, já que não há uma Legislação específica para essa modalidade de educação. Por fim, como essa modalidade de educação tem se ampliado especialmente no campo do Terceiro Setor, discuto algumas considerações sobre as estruturas legais das organizações que o compõem e que desenvolvem as atividades ou programas de educação não formal.

O CAPÍTULO 2 - CONCEPÇÕES SOBRE EDUCAÇÃO NÃO FORMAL - nesse capítulo apresento a fundamentação teórica da educação não formal baseada nas concepções e perspectivas de três importantes autores, que sem dúvida são de fundamentais para o desenvolvimento da pesquisa, pois são autores que abordam aspectos fundamentais que norteiam as práticas educativas não formais. Assim, esse capítulo está subdividido, em três partes: na primeira parte essa fundamentação está baseada nas concepções de Libâneo (2001), na segunda parte nas concepções de Gohn (2008) e na terceira parte nas concepções de Afonso (1989).

O CAPÍTULO 3 - METODOLOGIA DA PESQUISA - nesse capítulo apresento a descrição sobre os caminhos da pesquisa com o objetivo de expor toda a trajetória percorrida para o desenvolvimento da pesquisa e a respectiva metodologia utilizada para dar sustentação ao problema de pesquisa investigado.

O CAPÍTULO 4 - RESULTADOS DA PESQUISA - nesse capítulo apresento a interpretação dos dados da pesquisa, em relação à trajetória formativa dos profissionais de pedagogia que trabalham nos espaços de educação não formal. Esse capítulo visa 
responder as questões norteadoras da pesquisa, eixo principal que fundamentou 0 desenvolvimento empírico da referida temática.

Nas Considerações Finais será apresentada uma análise e uma reflexão mais profunda sobre o objeto em estudo, em que apresento as descobertas realizadas no decorrer da pesquisa, na perspectiva de que permitam uma maior aproximação e discussão da Universidade com essa temática. 


\section{CAPÍTULO 1 \\ BREVE HISTÓRICO DA EDUCAÇÃO NÃO FORMAL}

\subsection{0 surgimento da Educação não formal no Brasil}

A educação formal possui um papel central na formação do ser humano, principalmente no que diz respeito ao acesso aos conhecimentos historicamente sistematizados pela sociedade. Assim, para entender melhor os processos de organização e desenvolvimento da educação atual e os seus espaços de ações concretas é preciso ultrapassar o julgamento de que a educação é um processo exclusivo da escola.

Dessa forma, pensar a educação envolve algo muito mais amplo do que pensar somente nas escolas. A compreensão de que o sujeito se educa na relação com outros sujeitos e com o mundo no qual estão inseridos, aliada ao entendimento da educação como um processo permanente, contribui fundamentalmente para sinalizar a grande diversidade de modalidades educativas que não correspondem ao modelo escolar.

Para Brandão (2007, p.13) a educação, existe onde não há escola e por toda a parte pode haver redes e estruturas sociais de transferência de saber de uma geração à outra, onde ainda não foi sequer criado a sombra de algum modelo de ensino formal $\mathrm{e}$ centralizado.

As especificidades da educação são muitas, entre elas a da educação não formal, que vem ocupando um espaço que merece atenção não só por promover a inserção e a ampliação de atuação para os profissionais de pedagogia. E, sim, por deixar claro que essa modalidade de educação é uma prática necessária nesse novo cenário educacional.

Antes de aprofundarmos a discussão na questão da inserção e da atuação do pedagogo nos espaços de educação não formal, é necessário entender como se dá o 
surgimento dessa modalidade de educação e quais os fatores que contribuíram para a sua consolidação no cenário brasileiro.

Historicamente, no Brasil a expressão educação não formal começa a aparecer relacionada ao campo pedagógico concomitantemente a uma série de críticas ao sistema formalizado de ensino. Esse momento começa a ser percebido não só pelo campo pedagógico, como também por diferentes setores da sociedade mais ampla como serviços sociais, a área da saúde e outros, como um campo impossibilitado de responder a todas as demandas sociais que lhe são impostas.

De acordo com Trilla (1996) o termo educação não-formal aparece no final da década de 60 , período em que surgem vários estudos sobre a crise na educação. Além disso, a proximidade na compreensão geral da educação como sinônimo de escola, fez com que passasse a ser difundida e evidenciada como a crise da educação escolar ou formal.

Assim o contexto do surgimento da educação não-formal se dá não só por críticas às ações formais de ensino, mas também pelas questões e mudanças sociais que a sociedade veio passando. Mudanças sociais que se fortalecem no Brasil a partir da década de 80 , quando também se fortalece a defesa dos direitos da criança e do adolescente.

É nesta perspectiva, a partir da década de 90, devido às mudanças na economia e nas formas e relações próprias do mundo do trabalho, a demanda para a educação se modifica e amplia suas necessidades para além dos conteúdos programáticos e curriculares atribuídos e desenvolvidos pela educação formal. Ou seja, a educação passa a atuar em diferentes espaços e de forma alternativa, caracterizando-se como educação não-formal por estar fora dos âmbitos escolares e ter uma característica mais cultural e social.

O que parece importante considerar é que a educação não formal, como área do conhecimento pedagógico, passou a ser observada como uma área válida e possibilitadora de mudanças. Mudanças, inclusive, da própria concepção de educação, 
a partir de seu aparecimento e de sua inclusão como área pedagógica em documentos e artigos relevantes da área educacional, ganhando espaço e status de uma nova área educacional em oposição ao que estava em crise.

Assim o reconhecimento da educação não formal está intimamente ligado ao processo de questionamento da hegemonia da instituição escolar. Como afirma Afonso:

A crescente visibilidade social do campo da educação não formal (...) não é separável das reproduções e dos discursos em torno da chamada crise da educação escolar. Muito embora, os discursos sobre a crise da educação escolar sejam tão antigos como a própria escola, os fatores supostamente geradores da atual crise são hoje mais amplos e heterogêneos (2000, p.27).

Da afirmação do autor, destaca-se o aspecto da ampliação e diversificação dos fatores que agravam a crise escolar na atualidade e que simultaneamente contribuem para o fortalecimento das práticas educativas não escolares. Dentre os diversos fatores Afonso (2002) destaca:

- As condições atuais de expansão e internacionalização da economia capitalista num contexto de hegemonia ideológica neoliberal;

- A emergência do "capitalismo informacional", as mutações aceleradas nas formas de organização do trabalho e a inevitabilidade (também em grande medida, ideologicamente construída) do desemprego estrutural, a afetar sobretudo as futuras gerações;

- A permeabilidade e vulnerabilidade da escola às pressões sociais pressões que permitem que essa aceite, quase sempre passivamente ser o "bode expiatório" para as crises econômicas cada vez mais crescentes;

- A constatação, sinalizada em trabalhos recentes, de que a escola, já não sendo capaz de cumprir cabalmente os mandatos que há muito Ihe foram atribuídos, continua (paradoxalmente) a ser pressionada para assumir novos mandatos, à medida que os problemas sociais aumentam e diversificam e se complexificam (p. 27).

Outros fatores, no entanto, foram importantes antes mesmo da crise escolar, mas não foram suficientes para dar à educação não formal o status de área 
educacional. Entre os fatores importantes para o surgimento da educação não formal, estão tanto às mudanças ocorridas na estrutura familiar burguesa, quanto aquelas resultantes das modificações nas relações próprias do trabalho.

$\mathrm{Na}$ sociedade atual, o fato das famílias extensas estarem diminuindo ou terem diminuído de tamanho na sua constituição dificulta e impossibilita a convivência com os próprios familiares, assim além das crianças não possuírem o espaço seguro de rua para desenvolverem a socialização, elas também não possuem um rol de convivência familiar que Ihes permita estabelecer maiores relações com o diferente em idade, gênero, classe social, etnia etc.

Um dos fatores desencadeantes dessa nova estruturação familiar foi o processo de urbanização que intensificou a migração rural/urbana, estimulando uma sensível diminuição das famílias extensas, favorecendo com que os centros urbanos apresentassem outra concepção de espaço coletivo, que ao longo dos tempos vem se tornando cada vez mais violento e inseguro.

Por tanto, as transformações do mundo moderno redirecionaram e reorganizaram a estrutura familiar. O contexto social após o período da revolução industrial passou a envolver principalmente, conformações e necessidades do trabalho e as famílias acabaram por optar a ter menos filhos em virtude do trabalho. Muitas vezes também em função do trabalho optam por residir em localidades distantes dos demais familiares.

Isso quer dizer que as condições que favoreciam a anterior conformação da antiga estrutura familiar que possibilitava a socialização e o desenvolvimento do processo educacional de uma maneira mais livre e de forma co-responsável entre familiares e escola, por exemplo, são cada vez mais raras.

Com o crescimento das cidades e da população urbana, a demanda de bens públicos básicos como moradia, água, esgoto, transporte e segurança cresceu geometricamente. Isso fez com que diversos grupos de pessoas se mobilizassem em 
razão de problemas eminentemente locais e de natureza urbana e social, vendo o Estado como uma instância inacessível.

Toda essa modificação, tanto no contexto do trabalho, como na vida urbana, desmonta a forma tradicional em que a sociedade estava organizada. Houve a necessidade dessa mesma sociedade se reorganizar e responder às mudanças, especialmente e principalmente no campo educacional, criando novas formas de trabalhar com a educação em diversos espaços.

Essa nova forma de trabalhar com a educação começa a se desenvolver em diferentes espaços e de diferentes maneiras, caracterizando o que se denomina de educação não formal, suprindo de certa forma as diversas necessidades educativas que vieram de diferentes demandas como cuidado, formação, ambientes seguros e profissionais qualificados entre outras.

Todas essas demandas expandidas se refletem também no ambiente educacional. Portanto, a diferença está no fato de terem se modificado, ou de estarem se modificando as instâncias responsáveis pela educação no mundo atual, isto é, uma função social que não mais se restringe à família e à escola.

Outro fator que interferiu no surgimento e no crescimento do campo da educação não formal está relacionado às necessidades e exigências das indústrias e do mercado profissional, que nem sempre encontram profissionais habilitados, para suprir a demanda existente. A dificuldade para se encontrar tais profissionais se dá não só no sentido desses possuírem certificação esperada e desejada, mas na distância percebida entre a formação oferecida pela escola formal e a velocidade com que ocorrem as mudanças e as atualizações no mercado profissional.

Em meio a esse cenário, é perceptível a fragilidade do Estado no tocante à promoção do status de bem-estar social, ou seja, de saúde, moradia, segurança e em especial a educação. Fator esse que abriu caminho para o crescimento do chamado Terceiro Setor, atualmente considerado o principal espaço de desenvolvimento de atividades da educação não formal. 
O Terceiro Setor é representado pelas Organizações da Sociedade Civil, que são na verdade um conjunto de instituições que se distingue do Estado, embora promova direitos coletivos e do mercado. Pode ser entendido também como um conjunto de associações e organizações livres, não pertencentes ao Estado e não econômicas que, entretanto, têm comunicação com o campo público e com os componentes sociais.

Essas organizações têm características comuns, que se manifestam tanto na retórica como em seus programas e projetos de atuação, pois fazem contraponto às ações do governo já que os bens e serviços públicos resultam da atuação do Estado e também da multiplicidade de várias iniciativas particulares.

Outra característica dessas organizações é que elas fazem contraponto também às ações do mercado, pois abrem o campo dos interesses coletivos para a iniciativa individual. Isso dá maior dimensão aos elementos que as compõem, pois realçam o valor tanto político quanto econômico das ações voluntárias sem fins lucrativos e por fim projetam uma visão integradora da vida pública, pois enfatizam a complementação entre ações públicas e privadas.

É válido ressaltar que com o constante crescimento do Terceiro Setor, no qual a sociedade civil passa a ter também participação e responsabilidade pelas as questões educacionais e sociais a educação não formal ganha espaço. Isso porque as escolas responsáveis pela educação e legitimadamente constituídas e aceitas pela sociedade já não conseguem de maneira satisfatória e suficiente dar conta das diversas demandas educacionais.

No Brasil, a educação não formal nos últimos tempos tem uma característica forte de atuar com pessoas de baixa renda e este serviço é prestado pelo setor público e diferentes segmentos da sociedade civil que vão desde ONGs (Organização não governamental) a instituições que mantêm parcerias com empresas. O objetivo desses espaços de educação não formal na sua maioria visa o processo de inclusão social e incluem atividades ou projetos sociais que visam formação e a qualificação profissional para a inserção no mundo do trabalho. 
Por tanto, o movimento e a ascensão da educação não formal estão ligados à existência de diferentes práticas que eram mediadas pelas relações educacionais, mas que não eram consideradas como educação por não obedecerem a uma série de requisitos formais. Por outro lado, eram práticas educativas que possibilitavam a construção de diferentes modos de vivenciar e de compreender o processo de ensinoaprendizagem.

Dessa forma, é possível dizer que a modalidade de ensino denominada de educação não formal surge enquanto uma nova forma de organizar e perceber a relação ensino-aprendizagem, educador/educando. Mas é preciso aliar esta idéia à compreensão de que independente do contexto onde se dá o processo educacional, ou seja, seja ele em espaços formais ou em espaços não formais, esse processo educativo ocorra com qualidade.

Assim, a educação não formal, apesar de apontar e oferecer outras possibilidades diferentes da educação formal, pois são processos menos burocratizados, menos hierarquizados e mais rápidos na formação do sujeito, não tem a intenção de ser a salvação do sistema formal de ensino ou tomar seu lugar. Pelo contrário, conhecer melhor as potencialidades de ambas e relacioná-las a favor de todos é uma importante estratégia para que possam contribuir na formação intelectual, consciente e crítico do ser humano.

Isto quer dizer que o acesso à formação e a aquisição de conhecimentos oferecidos pela escola formal devem ser acessíveis a todos, como também as oportunidades oferecidas pelas diversas propostas de educação não formal, favorecendo uma relação democrática entre as diferentes e importantes vivências de socialização e formação. 


\section{2 A construção e a conquista de espaço do pedagogo no campo da educação não formal.}

As demais concepções sobre a educação não formal levam a discussão e a reflexão sobre a atuação do pedagogo além dos muros da escola, pois com as novas formas de organização do trabalho, os espaços e níveis de atuação desse profissional se ampliam, deixando-o em maior evidência nesse processo.

Em relação a esses níveis de atuação Libâneo diz que:

Considerando-se a variedade de níveis e atuação profissional do pedagogo, há que se convir que os problemas, os modos de atuação e os requisitos de exercício profissional nesses níveis não são necessariamente da mesma natureza, ainda que todos sejam modalidades de prática pedagógica. De fato, os focos de atuação e as realidades com que lidam, embora se unifiquem em torno das questões de ensino, é necessária a formação de profissionais não diretamente docentes. Ou seja, os níveis distintos de prática pedagógica requerem uma variedade de agentes pedagógicos e requisitos específicos de exercício profissional que um sistema de formação de educadores não pode ignorar (2000, p.53).

Neste sentido, repensar e propiciar mudanças em relação à formação do pedagogo é um dos caminhos para dar subsídios para que esse profissional possa estar atuando não só em espaços de educação não formal, mas em qualquer ambiente que necessite de ações pedagógicas.

Pode-se constatar o reflexo dessas questões no processo de formação dos pedagogos quando as Diretrizes Curriculares para o Curso de Pedagogia (CNE/CP Parecer 05/2005) apontam à necessidade de o curso abordar o exercício da docência e as diferentes funções do trabalho pedagógico tanto nas escolas como em contextos não escolares. Aspectos esses que devem estar explicitados no projeto pedagógico da instituição formadora assim como em suas atividades complementares e estágio curricular. 
Autores como Pimenta (2002) e Libâneo (2002) defendem a posição de que as áreas de atuação dos pedagogos são amplas em nossa sociedade e que isso deve ser considerado na formação desse profissional. Libâneo assim se manifesta sobre a vastidão do campo de atuação do pedagogo:

É quase unânime entre os estudiosos, hoje, o entendimento de que as práticas educativas estendem-se às mais variadas instâncias da vida social não se restringindo, portanto, à escola e muito menos à docência, embora estas devam ser a referência da formação do pedagogo escolar. Sendo assim, o campo de atuação do profissional formado em Pedagogia é tão vasto quanto são as práticas educativas na sociedade. Em todo lugar onde houver uma prática educativa com caráter de intencionalidade, há aí uma Pedagogia. (2002, p. 51).

Dessa forma, o pedagogo é um profissional que na sociedade atual pode atuar profissionalmente em diversos espaços educacionais onde haja necessidade de organizar, planejar, desenvolver e avaliar oportunidades de aprendizagem e desenvolvimento de habilidades.

Para Libâneo (2000) o mundo apresenta-se sob a forma de uma sociedade pedagógica e por isso necessita de ações pedagógicas mais bem definidas e consistentes para dar conta de todas essas transformações que a cada dia acontecem na sociedade. Assim, o campo de atuação do pedagogo não pode estar ligado somente à docência, é importante considerar que a docência faz parte da Pedagogia, mas não é a sua única identidade.

Esse novo cenário educativo ao qual a sociedade atual está inserida deixa claro que o processo educativo, ou melhor, as práticas educativas não estão mais restritas à formalidade, isto é, ao espaço escolar. O espaço educativo é um espaço aberto, que se estende além dos muros da escola, é um espaço que alcança também e principalmente o contexto social de cada educando e isso possibilita ao pedagogo sua inserção e atuação nos mais diferentes segmentos e áreas da sociedade.

Assim, um dos principais desafios para esse profissional atualmente é poder atuar em diversas áreas que necessitem de um trabalho educativo ou pedagógico, 
porém, para atuar nesses diversificados espaços educativos, é necessário mais do que uma formação em Pedagogia. É necessário buscar outros conhecimentos não só como forma de se diferenciar no mercado de trabalho, mas como forma de desenvolver um trabalho coerente de acordo com uma prática pedagógica que seja adequada aos denominados espaços de educação não-formal.

O que deve ficar claro é que essas diversificadas áreas de atuação, além da escola, têm muitas semelhanças com o trabalho desenvolvido por ela. Mas, ao mesmo tempo, elas diferem das práticas escolares, especialmente por serem desenvolvidas em espaços diferentes, em tempos diferentes, com metodologias diferentes, e requerem um processo de refletir continuamente sobre seu trabalho, buscando atualização não só de conhecimentos específicos da área educacional, mas sobre a área em que está atuando.

Diante dessa realidade, o aumento da demanda de pedagogos para desenvolver trabalhos que envolvem o processo ensino-aprendizagem nos espaços de educação não-formal é sem dúvida um momento de conquista para esses profissionais, em virtude de mais oportunidades de empregabilidade e uma aparente valorização profissional.

Por outro lado, é um momento que também suscita muitas questões e preocupações tanto do ponto de vista de sua atuação, como especialmente em relação a sua própria formação. Isso porque o curso de Pedagogia desde a sua criação teve como característica básica a formação de profissionais para atuar na escola, ou seja, na educação formal.

Acontece que pela complexidade e pela diversidade da ação educativa que permeia a sociedade atual, é preciso pensar a formação do pedagogo para além de uma base teórica científica. Ou seja, pensar em uma formação que lhe proporcione também uma qualificação para que possa atuar em diversos campos educativos, isto é, dentro e fora do sistema formal de ensino. 
Entender por tanto a educação num sentido mais amplo é compreender que a sociedade atual é uma sociedade pedagógica com muitos campos e espaços de atuação, é entender a educação enquanto um processo ao longo da vida. Esse entendimento vem confirmar o que nos diz Brandão:

Ninguém escapa da educação. Em casa, na rua, na Igreja ou na escola, de um modo ou de muitos, todos nós envolvemos pedaços da vida com ela: para aprender, para ensinar, para aprender e ensinar. Para saber, para fazer, para ser ou para conviver, todos os dias misturamos a vida com educação. Com uma ou com várias: Educação? Educações. (1995, p.7).

Tendo como referências as novas tendências do mercado de trabalho a sociedade apresenta demandas sócio-educacionais que ultrapassam os limites formais e regulares da escola, o que possibilita ao pedagogo uma área de atuação bem vasta. Então quais seriam os espaços de educação não formal onde o pedagogo pode estar atuando?

De acordo com Gohn (2005) eles são múltiplos, podendo ser algo criado ou recriado e que vai de acordo com os objetivos do grupo social que se organiza. Assim, no contexto atual, é possível encontrar, por exemplo, pedagogos desenvolvendo atividades em diversos segmentos da sociedade, pois os espaços de educação não formal são tão extensos e quanto complexos.

Para Fireman (2006), no contexto atual podemos encontrar pedagogos desenvolvendo atividades no mais variados segmentos da sociedade. Por exemplo, nas organizações governamentais e organizações não-governamentais (ONGs), os pedagogos atuam com planejamento, coordenação e execução de atividades e projetos educacionais que podem envolver a área da saúde, meio ambiente, cultura, formação e qualificação profissional, inclusão social, direitos humanos etc.

$\mathrm{Na}$ área da saúde, é possível encontrar o pedagogo atuando com o planejamento e a execução de programas de orientação e educação preventiva, envolvendo a mídia falada e escrita, em hospitais, em acompanhamento e reforço 
escolar, com atividades lúdicas para entretenimento de crianças hospitalizadas por longo período.

O campo do pedagogo nas empresas já está mais sólido, pois muitas empresas já vêm construindo o seu próprio corpo docente ou contratando empresas de consultoria, o que facilita a sua inserção nesse universo. Nesse contexto, o pedagogo pode desenvolver e coordenar projetos educacionais voltados para a divulgação de produtos, programas de avaliação de desempenho, cultura organizacional, qualificação e requalificação dos funcionários na perspectiva do mercado de trabalho etc.

Outro campo em que é possível a atuação do pedagogo é na área de turismo. Nesse universo ele pode em conjunto com os guias turísticos, desenvolver atividades educativas que visem não apenas conhecer determinada localidade, mas aprender sobre sua história e cultura numa perspectiva do multiculturalismo, da valorização das diversidades culturais e da consciência para a preservação ecológica.

Já é possível também encontrar pedagogos inseridos nos museus. Nesse contexto, cabe a ele desenvolver atividades educacionais, ou estratégias educativas que proporcionem aos visitantes compreender a importância da memória cultural e de sua relação com a sociedade atual.

O pedagogo pode ainda atuar ou desenvolver atividades educativas em instituições culturais, bibliotecas, educação ambiental, educação para o trânsito, colônia deferias, clubes recreativos, enfim em qualquer área da sociedade que necessite de planejamento, coordenação e execução de atividades que visam à educação e à formação humana.

Nesse sentido, toda área educativa, seja ela formal ou não formal, o trabalho desenvolvido pelo pedagogo tem caráter multidisciplinar, o que muda, são os métodos e as técnicas do processo ensino-aprendizagem. Eles se diferenciam de acordo com a realidade em que se dá esse processo, com os objetivos que se quer atingir e com o modo de atuar e planejar a ação educativa. 
De acordo com Libâneo (2000), os processos educativos que ocorrem na sociedade são tão complexos e multifacetados, não podendo ser investigado à luz de apenas uma perspectiva e, muito menos, reduzido ao âmbito escolar.

Diante dessas constatações é possível dizer que a presença do pedagogo nesses diversos universos educativos se caracteriza por uma conscientização de que a educação deve ser prioridade em toda sociedade desenvolvida e principalmente, na sociedade em desenvolvimento econômico, pois ela significa a base da formação humana e a sustentação dessa sociedade.

Segundo Gadotti:

A educação é um dos requisitos fundamentais para que os indivíduos tenham acesso ao conjunto de bens e serviços disponíveis na sociedade. Ela é um direito de todo ser humano como condição necessária para ele usufruir outros direitos constituídos numa sociedade democrática. Por isso o direito à educação é reconhecido e consagrado na legislação de praticamente todos os países e, particularmente, pela Convenção dos Direitos da Infância das Nações Unidas ( particularmente os artigos 28 e 29). Um outro exemplo é o Estatuto da Criança e do Adolescente do Brasil. Negar o acesso a esse direito é negar o acesso aos direitos humanos fundamentais. É um direito de cidadania, sempre proclamado como prioridade, mas nem sempre cumprido e garantido na prática. ( 2005, p.01).

A formação humana requer um profissional que seja capaz de refletir, analisar e pesquisar situações de ensino-aprendizagem coerente com os mais diversos contextos que se apresentam na sociedade atual. E o pedagogo é o profissional que no momento vem sendo solicitado a responder por esse processo ensino-aprendizagem, porque é o profissional que vêm assumindo o papel de trabalhar com a educação, nas várias esferas da sociedade, tendo como objetivo a formação humana e em conseqüência o desenvolvimento da sociedade.

A presença do pedagogo nos espaços de educação não formal é importante para a flexibilidade e amplitude que caracterizam esses espaços. Pois essa diversidade que também é umas das características da educação não formal, permite o crescimento das propostas na relação entre os diferentes saberes e maneiras de fazer a educação, 
possibilitando a emergência de outros e muitos jeitos de organizar e vivenciar o processo educacional.

Por tanto a construção e a conquista de espaço do pedagogo no campo da educação não formal, já é sem dúvida uma realidade no Brasil. Pois tanto o trabalho cotidiano desses profissionais que atuam nesses contextos, assim como as pesquisas que vêm sendo desenvolvidas nessa área deixa claro como o movimento dessa modalidade de educação vem se ampliando e se fortificando na sociedade atual.

\section{30 que diz a Legislação sobre a educação não formal}

Historicamente, no Brasil, inúmeros movimentos sócio-políticos contribuíram para a construção de uma concepção mais ampla da educação, que incorporasse a articulação entre os níveis e modalidades de ensino, bem como os processos educativos ocorridos fora do ambiente escolar, nos diversos momentos da prática social.

Essa concepção de educação, além de ampliar os espaços por onde pode ocorrer, sinaliza para a importância de que ela seja um processo contínuo de formação, ao longo da vida. Assim, para se concretizar enquanto direito inalienável do cidadão, em consonância com o Art. $1^{\circ}$ da Lei de Diretrizes e Bases da Educação Nacional, a prática social da educação deve ocorrer em espaços e tempos pedagógicos diferentes, para atender as diferenciadas demandas.

E é justamente desses processos educativos que ocorrem fora do ambiente escolar formal de educação que a referida pesquisa destaca o entendimento da educação enquanto processo de uma prática social constituída e constituinte das relações sociais mais amplas.

No intuito de entender melhor os processos educativos que ocorrem fora do ambiente escolar formal de educação, ou melhor, o que são os espaços de educação 
não formal, é importante primeiramente entender o que é um espaço formal de educação.

De acordo com Lei 9394/96 de Diretrizes e Bases da Educação Nacional, o espaço formal é a escola com todas as suas dependências, é o local onde a educação ali realizada é formalizada, garantida por Lei e organizada de acordo com a uma padronização nacional. Compreendendo então que o espaço de educação formal é um espaço escolar, é possível dizer que o espaço de educação não formal é qualquer lugar diferente da escola onde pode ocorrer uma ação educativa.

De acordo com o Instituto Nacional de Estudos e Pesquisas Anísio Teixeira (INEP), conceitua-se educação não formal como:

Atividades ou programas organizados fora do sistema regular de ensino, com objetivos educacionais bem definidos. 2. Qualquer atividade educacional organizada e estruturada que não corresponda exatamente à definição de 'educação formal'. 3. Processos de formação que acontecem fora do sistema de ensino (das escolas às universidades). 5. Tipo de educação ministrada sem se ater a uma seqüência gradual, não leva a graus nem títulos e se realiza fora do sistema de Educação Formal e em forma complementar. 6. Programa sistemático e planejado que ocorre durante um período contínuo e predeterminado de tempo. (Fontes em Educação. Comped, 2001).

Embora pareça simples, a definição de educação não formal é ainda de difícil entendimento, primeiramente porque não há uma legislação específica para essa modalidade de educação. O que se observa na Lei de Diretrizes e Bases da Educação Nacional - LDB 9394/96, que estabelece os princípios e as finalidades da Educação Nacional é a constatação de que a educação na sua forma mais ampla abrange sim a educação não formal. O que abre precedentes para algumas considerações do que se denomina modalidade de educação não formal.

A Lei de Diretrizes e Bases da Educação Nacional - LDB 9394/96, de 20 de dezembro de 1996, em seu Art. 1ํ diz: 
(...) a educação abrange os processos formativos que se desenvolvem na vida familiar, na convivência humana, no trabalho, nas instituições de ensino e pesquisa, nos movimentos sociais e organizações da sociedade civil e nas manifestações culturais. (p.15)

Assim, se por um lado, ela reconhece que a educação é desenvolvida nas instituições de ensino como Escolas de Educação Básica - Educação Infantil, Ensino Fundamental e Ensino Médio, inclusive na modalidade de Educação de Jovens e Adultos e de Educação Superior, por outro lado, ela também reconhece que a educação é desenvolvida fora delas. Embora sem a formalização, a organização, os métodos e a sistematização que caracterizam a educação formal nas escolas de diferentes níveis, etapas e modalidades da Educação Básica e da Educação Superior.

O entendimento da norma contida nesse $\S 1^{\circ}$ do artigo $1^{\circ}$ da Lei de Diretrizes e Bases da Educação Nacional é de fundamental importância para a correta compreensão e interpretação de toda Lei. É ela que delimita o seu âmbito de regulação, tratando apenas, o que não é pouco, da educação escolar, que se desenvolve, predominantemente, por meio do ensino, em instituições próprias.

Desse modo, o Título VI da Lei de Diretrizes e Bases da Educação Nacional, dedicado aos profissionais da educação, quando trata dos professores, deve ser lido e interpretado como referente aos docentes da educação escolar formal e não aos que ensinam fora dela, desenvolvendo atividades docentes na educação não formal, na família, na convivência social, no trabalho, nas manifestações culturais, e nos movimentos sociais e organizações da sociedade civil.

Sem dúvida, que múltiplos agentes ensinam, com diferentes meios, em diversas situações, tempos e ambientes educativos não formais, sem serem habilitados para a docência na Educação Escolar Básica ou Superior, estes últimos, evidentemente só podem atuar professores devidamente habilitados.

Os espaços de educação não formal desenvolvem obviamente, atividades educacionais que podem ser complementares sim à educação escolar regida pela Lei de Diretrizes e Bases da Educação Nacional e por normas que dela decorrem, no 
âmbito dos órgãos normativos dos respectivos sistemas de ensino, ou ainda de forma independente.

Entretanto, esses espaços que desenvolvem cursos e ou programas de educação não formal, assim como as instituições que os ministram não compõem quaisquer dos sistemas de ensino previstos na Lei de Diretrizes e Bases da Educação Nacional.

Assim, essas instituições que desenvolvem cursos e ou programas de educação não formal funcionam de forma independente dos sistemas de ensino e não são por eles regulados ou supervisionados. Alguns desses cursos e programas educativos podem até estar ligados, de alguma forma, a instituições escolares, podendo até mesmo ocorrer dentro dessas instituições, mas não integram o portfólio de suas programações escolares regulares, as quais são todas elas, reguladas pelo poder público.

De acordo com o Ministério da Educação (MEC):

A educação não-formal pode ocorrer dentro de instituições educacionais, ou fora delas, e pode atender a pessoas de todas as idades. Dependendo dos contextos nacionais pode compreender programas educacionais que ofereçam alfabetização de adultos, educação básica para crianças fora da escola, competências para a vida, competência para o trabalho e cultura no geral. (Fontes em educação. Comped, 2001).

Por tanto, se esses cursos ou programas não estiverem incluídos no projeto pedagógico da escola que desenvolve a educação escolar formal e não constarem dos currículos dos cursos ofertados, em regime de cooperação ou de intercomplementariedade, será entendido como cursos livres. Principalmente por não serem considerados como especificamente escolares, nos termos da própria Lei de Diretrizes e Bases da Educação Nacional.

Dessa forma, a educação não formal por não possuir um currículo definido, se torna bastante flexível e menos burocrática, daí poder ocorrer em diversos espaços 
diferentes da sala de aula e da escola, não necessitando de avaliações específicas para obtenção de certificado de aprendizagem.

A modalidade educação não formal tem se ampliado especialmente no campo do Terceiro Setor, daí a importância de conhecer melhor esse campo para que se percebam as estruturas legais de atuação das organizações que o compõem e que desenvolvem as atividades ou programas de educação não formal.

Historicamente pode-se dizer que no Brasil a Igreja, principalmente a católica, teve e tem papel decisivo na formação do Terceiro Setor no Brasil. As Santas Casas foram pioneiras na área e, após a proclamação da República, quando da separação entre Estado e Igreja, tornaram-se as primeiras organizações sem fins lucrativos do país. As Instituições ligadas a Igrejas protestantes, espíritas e afro-brasileiras também têm desenvolvido papel importante na conformação do Terceiro Setor no país, ainda que numericamente sejam menores.

A expressão Terceiro Setor é recente, apenas na última década o termo ganhou força e é utilizado para fazer referência ao conjunto de sociedades privadas ou associações que atuam no país sem finalidade lucrativa. É um setor que atua especificamente na execução de atividades de utilidade pública e possuem gerenciamento próprio e contam com uma grande quantidade de mão-de-obra voluntária (que não recebem remuneração pelo trabalho).

O Terceiro Setor é mantido com recursos de doações de empresas e pessoas físicas e, também, com repasse de verbas públicas. Existem também muitas associações que conseguem obter recursos através da organização de festas, jantares, bazares e venda de produtos etc.

As associações do Terceiro Setor atuam, principalmente, prestando serviços para pessoas carentes que não podem contratar serviços do setor privado (segundo setor). Como o setor público (primeiro setor) não consegue, em nosso país, atender com qualidade todas as pessoas necessitadas, o Terceiro Setor assume um papel de fundamental importância, onde têm como objetivo principal a melhoria da qualidade de 
vida das pessoas necessitadas. Portanto, atuam nas áreas de educação, saúde, esportes, lazer, orientação vocacional, qualificação profissional, cultura etc.

Entre as organizações que fazem parte do Terceiro Setor, podemos citar principalmente as ONGs (Organizações Não Governamentais) e OSCIPs (Organizações da Sociedade Civil de Interesse Público), além de outras organizações com várias denominações como centro, instituto, rede, liga, núcleo, lar, instituição, fraternidade, serviço, casa etc.

Com o advento do novo Código Civil, em vigor desde janeiro de 2002, ficou estabelecidos, nos artigos 44 e seguintes, que os nomes juridicamente corretos para as organizações que compõe o Terceiro Setor são Associação e Fundação, cada uma delas com características distintas. Contudo isso não quer dizer que não se possam usar os demais termos de acordo com as finalidades propostas, desde que se mencione expressamente no estatuto.

Além dessas mudanças por força do novo Código Civil, poucos anos antes, em 1999, aprovou-se a Lei 9.790 - Organizações da Sociedade Civil de Interesse Público (OSCIP), também conhecido como Lei do Terceiro Setor, considerada marco legal do Terceiro Setor. A referida Lei dispõe sobre a qualificação de pessoas jurídicas de direito privado sem fins lucrativos como Organizações da Sociedade Civil de Interesse Público e institui e disciplina o Termo de Parceria, além de estabelecer uma nova disciplina jurídica para elas.

As inovações preponderantes dessa Lei estão à possibilidade de remunerar os dirigentes; previsão de formação de parcerias com o poder público, por meio do Termo de Parceria, bem como entre entidades qualificadas como OSCIP para fomento de suas atividades; observância dos mesmos princípios que norteiam a Administração Pública, que são a legalidade, impessoalidade, moralidade, publicidade, economicidade e eficiência; qualificação do título de OSCIP, concedida pelo Ministério da Justiça depois de cumpridas todas as exigências da Lei. 
A Lei 9.790/99 também elenca um rol taxativo no que se refere aos objetivos sociais, ou seja, para que receba a qualificação como OSCIP, a entidade deve ter uma das seguintes finalidades: promoção social; promoção da cultura, defesa e conservação do patrimônio histórico e artístico; defesa, preservação e conservação do meio ambiente e promoção do desenvolvimento sustentável; promoção gratuita da saúde, da educação, da segurança alimentar e nutricional, do voluntariado, do combate à pobreza; experimentação, não lucrativa, de novos modelos sócio-produtivos e de sistemas alternativos de produção, comércio, emprego e crédito; estudos e pesquisas, desenvolvimento de tecnologias alternativas, produção e divulgação de informações e conhecimentos técnicos e científicos que digam respeito às atividades mencionadas no artigo $3^{\circ}$ da Lei 9.790/99; promoção da ética, da paz, da cidadania, dos direitos humanos, da democracia e de outros valores universais.

Ressalta-se que tal Lei também enumera que não pode receber qualificação de OSCIP no inciso III do artigo $2^{-}$as instituições religiosas ou voltadas para a disseminação de credos, cultos, práticas e visões devocionais ou confessionais.

À medida que as entidades e organizações do Terceiro Setor passaram a ocupar espaço público, assumindo responsabilidades, constatou-se o aumento de sua importância política e social pela participação cidadã e, principalmente, de sua importância econômica em virtude do potencial de criação de novos empregos, prestação de serviços e controle social.

Em se tratando de termos jurídicos e títulos para o Terceiro Setor, a Legislação Brasileira permite que a sociedade se organize nas seguintes formas jurídicas: Associação, Fundação, Organizações Religiosas, Utilidade Pública Federal, Registro no Conselho Nacional de Assistência Social (CNAS), Certificado de Entidade Beneficente de Assistência Social (CEBAS) e Organização da Sociedade Civil de Interesse Público (OSCIP).

A Associação pode ser definida como pessoa jurídica criada com base na união de idéias e esforços de pessoas em torno de um propósito que não tenha finalidade lucrativa. De acordo com Diniz: 
(...) tem-se associação quando não há fim de lucro ou intenção de dividir o resultado, embora tenha patrimônio, formado por contribuição de seus membros para obtenção de fins culturais, educacionais, esportivos, religiosos, recreativos etc. Nem sempre uma associação terá fins sociais, exemplo disso sãos os clubes esportivos com acesso restrito a seus sócios. (1997, p.51).

Diante das alterações do novo Código Civil brasileiro, é preciso esclarecer que as organizações do Terceiro Setor constituídas como Associações são entidades sem finalidade econômica, entendendo-se por finalidade aquilo a que se presta a entidade, ou seja, o fim para o qual foi concebida. Entretanto, é permitida a atividade econômica desde que não gere lucro e este seja distribuído, sendo os recursos gerados aplicados nas atividades da instituição.

A Fundação poder ser entendida como o patrimônio destinado a servir, sem intuito de lucro, a uma causa de interesse público determinada, que adquire personificação jurídica por iniciativa de seu instituidor. Podem ser criadas pelo governo (são pessoas jurídicas de direito público), por indivíduos ou empresas.

As Organizações Religiosas, anteriormente enquadradas na figura jurídica de associação, passaram por força da Lei Federal ํㅡ 10.825/03 a ser classificadas como uma terceira categoria jurídica, não constituindo uma forma de organização do ponto de vista jurídico.

As sociedades civis, associações ou fundações poderão solicitar ao Ministério da Justiça a declaração de Utilidade Pública Federal desde que sirvam desinteressadamente à coletividade e cumpram os requisitos legais. Ao ser declarado de Utilidade Pública Federal, a entidade tem de apresentar um relatório de serviços prestados, além de demonstrativos de receitas e despesas do exercício.

Poderão solicitar registro nos CNAS às entidades sem fins lucrativos que promovam as atividades elencadas na Resolução no 31/1999 como a integração de trabalhadores ao mercado de trabalho, assistência educacional ou de saúde, entre outras. 
Para conseguir o Certificado de Entidade Beneficente de Assistência Social (CEBAS) a entidade deve demonstrar que nos três anos imediatamente anteriores ao pedido esteve legalmente constituída e em funcionamento, que esteve inscrita no Conselho Municipal de Assistência Social de sua cidade sede e registrada no CNAS. Aprovado o pedido, será expedido o certificado de entidade de fins filantrópicos, com validade de três anos, podendo ser renovado por igual período.

As OSCIPs são organizações que efetivamente têm finalidade pública. Para obter a qualificação, a organização deve ser pessoa jurídica de direito privado sem finalidade lucrativa, atender aos objetivos sociais e as normas estatutárias previstas em Lei e apresentar cópia dos documentos exigidos.

Compreender o cenário do Terceiro Setor não é fácil, mesmo porque há uma diversidade muito grande de organizações que o integram, constituídas juridicamente como associações ou fundações, laicas ou de confissão religiosa. A abrangência de suas ações vai desde a prática puramente assistencialista e caritativa até pesquisas científicas financiadas por empresas ou instituições privadas, que buscam respostas para as grandes questões sociais, educacionais, ecológicas, dentre outras.

Por outro lado, a dimensão e o significado do Terceiro Setor necessitam ser compreendidos dentro de uma conjuntura social, já que no decorrer dos últimos vinte anos, ele tem se configurado num contexto marcado especialmente pela complexidade, instabilidade, mudanças, pobreza e desigualdade social. Daí ele ter se constituído atualmente no principal espaço de desenvolvimento da educação não formal.

O capítulo 2 foi pensado e organizado de forma a dar uma maior fundamentação teórica sobre a temática da educação não formal. Assim, ele está fundamentado na concepção de três autores, Libâneo (2001), Gohn (2008) e Afonso (1989) que são autores que abordam sobre a educação não formal e contribuem para um melhor entendimento sobre o diversificado campo dessa modalidade de educação. 


\section{CAPÍTULO 2 \\ CONCEPÇÕES SOBRE EDUCAÇÃO NÃO FORMAL}

Um dos fenômenos mais significativos dos processos sociais contemporâneos é a ampliação do conceito de educação e a diversificação das atividades educativas, levando, por consequência, a uma diversificação da ação pedagógica na sociedade. Isso porque pensar em educação nem sempre é pensar nas escolas, a educação entendida como necessidade básica e como um processo contínuo e permanente dos sujeitos, não está presente somente dentro das escolas, mas também no dia-dia de cada indivíduo.

$\mathrm{Na}$ visão de Haddad (2009) é possível aprender fora da escola e isso fica bem pertinente na pesquisa "Balanço da produção de conhecimentos sobre educação não escolar de adultos: educação e desenvolvimento", em que ele analisou toda a produção do que denomina de educação não escolar. Por meio do levantamento de todos os tipos de experiências não escolar ele enfatiza que existem outros caminhos para se aprender além das escolas formais.

Essa análise leva ao entendimento de que a sociedade atual vive um momento genuinamente pedagógico, ou seja, existe uma ação pedagógica múltipla na sociedade que ultrapassa o âmbito escolar formal, abrangendo esferas mais amplas da educação, criando outras formas de práticas educativas, como é o caso da educação não formal, uma modalidade educacional que vem se ampliando cada vez mais desfazendo aos poucos os nós que separam escola e sociedade.

\subsection{A educação não formal na perspectiva de Libâneo}

O contato com autores que produziram ou produzem especificamente sobre a educação não formal possibilita uma aproximação e uma compreensão maior do campo dessa modalidade de educação, pois a educação não formal ainda é um campo em 
crescimento. E por ser um campo relativamente em constituição, ainda são poucas as pesquisas nessa área, o que a torna ainda frágil do ponto de vista teórico.

Dessa forma, a escolha por autores como José Carlos Libâneo, Maria da Glória Gohn e Almerindo Janela Afonso, se dá no sentido de que cada autor trás uma abordagem interessante e diferente em relação às especificidades que norteiam a educação não formal.

Libâneo é um autor bastante sugestivo no processo de desenvolvimento teórico dessa pesquisa porque aborda e expõe as razões que justificam a existência da Pedagogia como "Ciência da Educação", área de formação do pedagogo.

Para Libâneo (2001) a Pedagogia tem um significado muito mais amplo, é um campo de conhecimentos sobre a problemática educativa na sua totalidade e historicidade e, ao mesmo tempo uma diretriz orientadora da ação educativa. Por tanto é o campo do conhecimento que se ocupa do estudo sistemático da educação, do ato educativo, da prática educativa como componente integrante da atividade humana que está inerente ao conjunto dos processos sociais.

Assim é possível dizer que não há sociedade sem práticas educativas e a Pedagogia não se refere apenas às práticas escolares, mas a um imenso conjunto de outras práticas, uma vez que o campo educativo é bastante vasto a educação ocorre em muitos lugares e sob várias modalidades, isto é, na família, no trabalho, na rua, na escola etc.

Entender o que se denomina educação no seu sentido mais amplo é compreendê-la enquanto prática social e é esse caráter de mediação social que explica as várias educações, suas modalidades e instituições, entre elas a educação não escolar, denominada educação não formal.

Nesse sentido, Libâneo (2001) se posiciona em relação à educação não formal, como práticas educativas que ocorrem em todos os contextos e âmbitos da existência individual e social humana, de modo institucionalizado ou não e sob várias 
modalidades. Esse entendimento é o que dá mais significado ao processo de educação não formal e da própria atuação do pedagogo nesse processo.

Porém como a educação não formal é um universo que envolve um trabalho com uma realidade complexa, a presença atuante de profissionais com preparação prévia sistemática e qualificada para uma atuação nas mais diversas instituições e ambientes da sociedade é imprescindível no sentido do enfrentamento das exigências colocadas pelo mundo atual.

Nesse contexto Libâneo (2005) discute três modalidades de educação, caracterizando-as do seguinte modo:

A educação informal corresponderia a ações e influências exercidas pelo meio, pelo ambiente sociocultural, e que se desenvolve por meio das relações dos indivíduos e grupos com seu ambiente humano, social, ecológico, físico e cultural, das quais resultam conhecimentos, experiências, práticas, mas que não estão ligadas especificamente a uma instituição, nem são intencionais e organizadas. A educação nãoformal seria a realizada em instituições educativas fora dos marcos institucionais, mas com certo grau de sistematização e estruturação. A educação formal compreenderia instâncias de formação, escolares ou não, onde há objetivos educativos explícitos e uma ação intencional institucionalizada, estruturada, sistemática (p.31).

Observando o aspecto da intencionalidade, Libâneo (2005) faz a distinção da educação formal e a não formal, apresentando esta última pelo baixo grau de estruturação e sistematização, que implicam sem dúvida relações pedagógicas, sem a formalização regulamentar do sistema educacional oficial. Como exemplo o autor cita como espaços e territórios de atuação da educação não formal, os movimentos sociais urbanos e rurais, os trabalhos comunitários, as atividades de animação cultural, os meios de comunicação social, os equipamentos urbanos culturais e de lazer como museus, cinemas, praças, áreas de recreação etc, as atividades de complementação curricular em conexão com a escola como feiras, visitas, excursões e outros tantos exemplos que nos mostram o vínculo estreito entre o formal e o não formal. 
Na concepção de Libâneo (2001), há duas características fundamentais do ato educativo propriamente dito, primeiro a de ser uma atividade humana intencional voltada para fins desejáveis do processo de formação e a segunda de ser uma prática social que só pode ser compreendida no quadro de funcionamento geral da sociedade da qual faz parte. Isso quer dizer que as práticas educativas de forma geral não se dão de forma isolada das relações sociais, sobretudo as práticas educativas não formais.

Fica claro então, que há uma diversidade de práticas educativas na sociedade e em todas elas, desde que se configurem como intencionais, está presente a ação pedagógica e a atuação do pedagogo, profissional que pode atuar em várias instâncias da prática educativa, em vários campos sociais da educação, decorrentes de novas necessidades e demandas sociais.

Nessa perspectiva, se destaca a formação de profissionais de pedagogia para atuar em contextos não escolares, pois é acentuada a consciência atual da importância e da necessidade da intervenção participante e significativa desses profissionais nesses novos campos educativos.

Por outro lado, entre os profissionais que se ocupam, direta ou indiretamente, de atividades no campo educacional, tem havido entendimentos bastante diversos e frequentemente parcializados do termo educação e de suas modalidades. Em boa parte devido à complexidade e multidimensionalidade do fenômeno educativo, a investigação de sua natureza, de suas especificidades e de suas funções pode ser feitas sob vários enfoques, o antropológico, o sociológico, o econômico, o psicológico, o biológico, o histórico e o pedagógico.

Assim, é inevitável que ocorram entendimentos diversos devido ao viés das várias áreas de conhecimento que se ocupam do fenômeno educativo, das diversas instituições que lidam com questões educacionais ou das experiências vivenciadas na prática. As consequências dessa problemática são as visões parcializadas e reducionistas, bem como as notórias dificuldades de precisão na definição de certos conceitos como educação formal, educação não formal etc. 
Além disso, por serem muitas as portas de entrada para o estudo da educação, faz-se necessário o esforço de clarificar o âmbito educativo e essa tarefa pertence à Pedagogia, que na condição de ciência da e para a educação, sintetiza as contribuições das demais ciências da educação, dando unidade à multiplicidade dos enfoques analíticos do fenômeno educativo.

Com isso, reconhece-se que os processos educativos ocorrentes na sociedade são complexos e multifacetados, não podendo ser investigados à luz de apenas uma perspectiva e, muito menos, reduzidos apenas ao âmbito escolar formal. O esclarecimento cada vez mais buscado do campo próprio da Pedagogia é requerido, não só por causa da amplitude e complexidade que vão assumindo as práticas educativas na sociedade globalizada, mas especialmente por outras instâncias e práticas do processo educativo que vão surgindo como a educação não formal.

O que deve ficar claro é que a educação formal e a educação não formal entrelaçam-se constantemente, uma vez que as modalidades de educação não formal não podem prescindir da educação formal (escolar ou não, oficial ou não), e a educação formal não pode separar-se da não formal, uma vez que os educandos não são apenas "alunos", mas participantes das várias esferas da vida social.

\subsection{A educação não formal na perspectiva de Gohn}

A educação tem sido proclamada como uma das áreas-chave para enfrentar os novos desafios gerados pela globalização e pelo avanço tecnológico na sociedade. Neste cenário, a educação ganha importância não só pelo elevado grau de competitividade que ampliou a demanda por conhecimentos e informação, mas pela qualidade e pelo tipo de educação a ser oferecida.

Neste contexto, as demandas sobre educação são múltiplas, e muitas delas não se situam na área da educação formal, na escola regular, mas emergem de múltiplos campos sociais. Para isso, novos desenhos procuram dar respostas aos 
desafios educacionais incluindo novas abordagens, metodologias e conteúdos cognitivos e sociais, de acordo com os novos paradigmas emergentes.

Trata-se do crescimento da educação não formal, uma modalidade de educação ainda pouco entendida do ponto de vista teórico e prático, mas de um desenvolvimento e de uma ampliação crescente na sociedade atual, gerando ainda uma discussão de certo ponto conflitante por ser uma concepção ampliada que alarga os domínios da educação para além dos muros escolares.

Nessa perspectiva a Gohn é uma autora fundamental porque além de trazer uma abordagem histórica sobre a trajetória da Educação não formal no Brasil, consegue demarcar as diferenças entre educação formal e não formal, que a seu ver podem parecer extremamente simples, mas que não podem ser confundidas como simplificadoras.

Para Gohn (2008) a educação não formal é um novo campo que se estrutura, abordando processos educativos que ocorrem fora das escolas, em processos organizativos da sociedade civil, ao redor de ações coletivas do chamado Terceiro Setor da sociedade, abrangendo movimentos sociais, organizações não governamentais e outras entidades sem fins lucrativos que atuam na área social, ou processos educacionais, frutos da articulação das escolas com a comunidade educativa, via conselhos, colegiados etc.

Ao analisar a educação não formal como um processo que tem sempre um caráter coletivo, ainda que o resultado do que se aprende seja absorvido individualmente, ela enfatiza que ao estudarmos a educação não formal devemos atentar para os aspectos que norteiam as práticas educativas que seriam as metodologias e os modos de funcionamento das mesmas, por ser um dos aspectos mais relevantes do processo de aprendizagem. 
De acordo com Gohn (2008):

A educação não formal designa um processo com quatros campos ou dimensões, que correspondem as suas áreas de abrangência. $O$ primeiro envolve a aprendizagem política dos direitos dos indivíduos enquanto cidadãos, isto é, o processo que gera a conscientização dos indivíduos para a compreensão de seus interesses e do meio social e da natureza que o cerca, por meio da participação em atividades grupais. Participar de um Conselho de escola poderá desenvolver essa aprendizagem. $O$ segundo, a capacitação dos indivíduos para o trabalho, por meio da aprendizagem de habilidades e desenvolvimento de potencialidades. $\mathrm{O}$ terceiro, a aprendizagem e o exercício de práticas que capacitam os indivíduos a se organizarem com objetivos comunitários, voltadas para a solução de problemas coletivos cotidianos. Não gosto do termo educação comunitária para esta modalidade, devido à carga ideológica que o conceito de comunidade comporta. Prefiro educação para a civilidade, uma arte que anda meio esquecida neste final de milênio. O quarto, e não menos importante, é aprendizagem dos conteúdos da escolarização formal em formas e espaços diferenciados. Aqui, o ato de ensinar se realiza de forma mais espontânea, e as forças sociais organizadas de uma comunidade têm o poder de interferir na delimitação do conteúdo didático ministrado bem como estabelecer as finalidades a que se destinam àquelas práticas (p.98).

Em outras palavras, para a autora a educação não formal é aquela em que se aprende via processos de compartilhamento de experiências, principalmente em espaços e ações coletivas cotidianas carregadas de valores e culturas próprias, o grande educador é o "outro". Ou seja, aquele com quem interagimos ou nos integramos, os espaços educativos localizam-se em territórios que acompanham as trajetórias de vida dos grupos e indivíduos, ou seja, fora das escolas, em locais informais, locais onde há processos interativos intencionais, guiado a luz das diretrizes de cada grupo.

Alguns autores denominam o aprendizado de conteúdos não escolares que ocorrem em espaços diferentes da escola, como sendo educação informal, mas para a autora essa terminologia e classificação é incorreta, pois trabalha-se com um paradigma bipolar onde existe apenas dois tipos de aprendizagem: o escolar e o não 
escolar, ou seja, tudo o que ocorre fora dos muros da escola é pensado como aprendizagem não escolar e perde seu caráter de educação propriamente dita.

Nesse contexto se define a educação não formal por uma ausência, em comparação ao que há na escola, isto é, a educação não formal seria algo não intencional, não planejado e não estruturado, tomando como único paradigma a educação formal. Por outro lado, ao contrário do que muitos pensam a educação não formal tem intencionalidade sim, ocorre de forma planejada, mas é claro dentro de uma outra estrutura de tempo e de espaço que não correspondem ao ensino escolar formal.

Os espaços onde se desenvolvem ou se exercitam as atividades da educação não formal são múltiplos como associações, organizações que estruturam e coordenam os movimentos sociais, organizações não governamentais (ONGs), espaços culturais etc. Entretanto, as categorias de espaço e tempo também têm novos elementos na educação não formal porque usualmente o tempo da aprendizagem não é fixado a priori e são respeitadas as diferenças existentes para a absorção e reelaboração dos conteúdos, implícitos ou explícitos no processo ensino-aprendizagem. Assim o espaço e o tempo também é algo criado e recriado segundo modos de ação previstos nos objetivos maiores que dão sentido ao fato de determinado grupo social estar se reunindo.

Em termos didáticos a autora aborda também a educação não formal em dois campos, o primeiro destinado a alfabetizar ou socializar conhecimentos que historicamente têm sido sistematizados por sujeitos das ações educativas, com uma estrutura e uma organização distinta das organizações escolares, abrangendo a área que se convencionou chamar de educação popular (conforme o uso corrente nos anos 70 e 80 e educação de jovens e adultos nos anos 90). O segundo campo, abrange a educação gerada no processo de participação social, em ações coletivas voltadas para o aprendizado de conteúdos da educação formal.

Na educação não formal a aprendizagem da escrita e da leitura pode ocorrer por procedimentos e métodos não oficiais, mas existe a preocupação de se socializar os mesmos conteúdos da escola formal, de repassar o mesmo acervo de 
conhecimentos historicamente acumulados pela humanidade. Entretanto, essa socialização é desenvolvida em espaços alternativos e com metodologias e sequências cronológicas diferenciadas, com conteúdos curriculares flexíveis, adaptados segundo a realidade dos sujeitos envolvidos nesse universo educativo.

Outra diferença fundamental é dada pelos objetivos das ações. Na educação não formal a cidadania é o objetivo principal, e ela é pensada em termos coletivos, ou seja, organizam-se processos de acesso à escrita e à leitura por meio de métodos de alfabetização para coletivos específicos como grupos de trabalhadores, grupo de jovens, grupos de adultos ou organizam-se processos de capacitação ou formação de acordo com determinadas demandas sociais.

Nessa perspectiva, um dos supostos básicos da educação não formal é o de que a aprendizagem se dá por meio da prática social, ou seja, é a experiência das pessoas em trabalhos coletivos que gera um aprendizado. A produção de conhecimentos ocorre não pela absorção de conteúdos previamente sistematizados, objetivando ser apreendidos, mas o conhecimento é gerado por meio da vivência de certas situações-problema.

As ações interativas entre os indivíduos são fundamentais para a aquisição de novos saberes e essas ações ocorrem fundamentalmente no plano da comunicação verbal, oral, carregadas de todo o conjunto de representações e tradições culturais que os indivíduos possuem.

É válido destacar que a educação não formal tem sempre um caráter coletivo, passa por um processo de ação grupal, é vivida como práxis concreta de um grupo, ainda que o resultado do que se aprende seja absorvido individualmente. Ou seja, o processo ocorre a partir das relações sociais. Mediadas por agentes assessores, e é profundamente marcado por elementos de intersubjetividade à medida que os mediadores desempenham o papel de comunicadores.

A educação não formal é uma área carente de pesquisa científica, com raras exceções, pois o que predomina é o levantamento sistemático de dados para subsidiar 
projetos e relatórios, realizados por organizações não governamentais, visando ter acesso aos fundos públicos que as políticas de parcerias governo e sociedade civil propiciam. Entretanto, existem ações de educação não formal que são extremamente significativas e que merecem om olhar diferenciado.

Assim, ao aprofundar estudos na área da educação não formal, percebe-se que esse novo campo de ação coletiva está sim em ação, mas parece que sob um olhar ainda ignorado por aqueles que desconhecem ou não se preocupam com esse sentido mais amplo que a educação tomou em nossa sociedade.

Por tanto, uma importante observação nessa discussão é não entender a educação não formal enquanto uma prática educativa que veio para substituir o ensino formal, pelo contrário, essa modalidade de educação cresceu e se ampliou na sociedade em virtude de demandas sociais.

São práticas educativas que estão gerando novas formas de se entender a educação além dos muros da escola, mas que ao mesmo tempo precisam e necessitam trabalhar em parceria com a escola, já que ela tem seu próprio espaço e pressupõe uma educação voltada para a complexidade do mundo, da vida e do trabalho.

A educação não formal é um campo valioso em saberes e precisa cada vez mais do apoio dos profissionais da educação para dar sentido e significado ao que ela se propõe, pois sua finalidade é abrir janelas de conhecimento sobre o mundo que circunda os indivíduos e suas relações sociais.

\subsection{A educação não formal na perspectiva de Afonso}

A educação na sua amplitude e complexidade, só é significativa quando ocorre em contextos significativos de ação, não sendo por isso apenas redutível aos espaços e tempos da instituição escolar, o que se traduz em uma descentralização dos saberes de domínio escolar formal e uma concomitante multiplicação de outros espaços possíveis de ações educativas. 
Nessa perspectiva, a ampliação desses diferentes contextos educativos não só enfraqueceu a hegemonia da instituição escolar como sendo o único e exclusivo espaço de ensino aprendizagem como vem promovendo um debate bastante sugestivo e pertinente a respeito das práticas de educação não formal.

No que concerne a esse debate o autor Afonso também se faz relevante no processo de construção da pesquisa porque além de fazer a distinção entre a educação formal, informal e não formal, aborda aspectos que segundo ele podem ter agravado a crise escolar e que acabaram por contribuir para o fortalecimento e crescimento de práticas educativas não formais.

Para o autor, a educação não formal surge em decorrência da necessidade de complementação ao ensino formal escolar público, que não conseguiu suprir todas as demandas das quais foi incumbida, com isso ele chama a atenção para novas formas de educação e novos contextos de aprendizagem que não se confinam à escola tradicional e que podem e devem constituir-se como um novo objeto real de estudo e pesquisa.

Afonso (1989) também aponta as diferenças entre o formal e o não formal em termos de oposição. Para ele, por educação formal entende-se o tipo de educação organizada com uma determinada sequência prévia e proporcionada pelas escolas. Enquanto que a designação não formal, embora obedeça a uma estrutura e a uma organização (mesmo que não seja essa a finalidade), diverge ainda da educação formal no que respeita a não fixação de tempos e locais e a flexibilidade na adaptação dos conteúdos de aprendizagem a cada grupo concreto. 
Afonso (1992) elaborou um quadro comparativo entre a educação formal e a não formal:

\section{TIPOS DE APRENDIZAGEM}

\begin{tabular}{|c|c|}
\hline ESCOLAS TRADICIONAIS & $\begin{array}{l}\text { ASSOCIAÇÕES DEMOCRÁTICAS PARA } \\
\text { O DESENVOLVIMENTO }\end{array}$ \\
\hline Apresentam um caráter compulsório & Apresentam um caráter voluntário \\
\hline Dão ênfase à instrução & Promovem sobre tudo a socialização \\
\hline $\begin{array}{lllll}\text { Favorecem } & 0 & \text { individualismo } & \text { e } & \text { a } \\
\text { competição } & & & & \end{array}$ & Promovem a solidariedade \\
\hline Visam à manutenção do status quo & Visam o desenvolvimento \\
\hline $\begin{array}{l}\text { Preocupam-se essencialmente com a } \\
\text { reprodução cultural e social }\end{array}$ & $\begin{array}{l}\text { Preocupam-se essencialmente com a } \\
\text { mudança social }\end{array}$ \\
\hline $\begin{array}{l}\text { São hierárquicas e fortemente } \\
\text { formalizadas }\end{array}$ & $\begin{array}{l}\text { São pouco formalizadas e pouco ou } \\
\text { incipiente hierarquizadas }\end{array}$ \\
\hline Dificultam a participação & Favorecem a participação \\
\hline $\begin{array}{l}\text { Utilizam métodos centrados no professor- } \\
\text { instrutor }\end{array}$ & $\begin{array}{l}\text { Proporcionam a investigação-ação e } \\
\text { projetos de desenvolvimento }\end{array}$ \\
\hline Subordinam-se a um poder centralizado & $\begin{array}{l}\text { São por natureza formas de participação } \\
\text { descentralizada }\end{array}$ \\
\hline
\end{tabular}

Essa diferenciação e a conseqüente caracterização de uma área específica da educação não formal vêm sendo formada a partir da observação de diferentes práticas, permeadas por relações educacionais, realizadas por diferentes espaços educativos, 
que embora não obedeçam a uma série de requisitos formais passaram a construir diferentes modos de vivenciar, compreender e sistematizar o processo de ensinoaprendizagem.

Rejeitando a ideia de uma sociologia da educação enclausurada na análise da escola e/ou dos processos sociais e organizacionais que condicionam a educação formal, o autor defende o alargamento da reflexão para além dos limites meramente escolares e propõe uma sociologia da educação não escolar que estude como se caracterizam os contextos educativos, sobretudo os contextos não formais, enquanto instâncias de reprodução ou mudança social.

Para o autor, a ampla e crescente visibilidade social do campo da educação não formal está ligada à crise da educação escolar. Talvez mais do que em qualquer outra época, as referências à crise da educação escolar no contexto atual remetem implícita e explicitamente para condicionantes econômicas, sociais e politico-ideológicas muito diversificadas e, consequentemente, as explicações produzidas e divulgadas são hoje mais heterogéneas e contraditórias.

De acordo com Afonso (1992) a crise da educação escolar não pode ser compreendida sem levar em consideração os seguintes fatos:

As condições actuais de expansão e internacionalização da economia capitalista num contexto de hegemonia ideológica neoliberal;

A emergência do "capitalismo informacional", as mutações aceleradas nas formas de organização do trabalho e a inevitabilidade (também, em grande medida, ideologicamente construída) do desemprego estrutural, a afetar sobretudo as novas gerações;

A permeabilidade e vulnerabilidade da escola às pressões sociais pressões que permitem que esta aceite, quase sempre passivamente, ser o "bode expiatório" para as crises económicas cada vez mais frequentes;

Os discursos vulgares que induzem os cidadãos a pensar que a falta de emprego é devida à não qualificação dos indivíduos, sendo esta, por sua vez, acriticamente atribuída à incapacidade estrutural da escola para 
preparar os estudantes em função das (supostas) necessidades da economia;

A perda de confiança no valor social dos diplomas, induzida pela distorções nas relações entre a educação e o mercado de trabalho (vejase, por exemplo, o crescente desemprego dos licenciados; a proliferação de empregos precários disputados por portadores de qualificações superiores às exigidas para o exercício das funções que the são propostas; a existência de contextos de trabalho indutores de "regressões culturais"...);

A centralidade dos meios de comunicação de massa que se constituem como fortes agentes de socialização secundária, substituindo ou neutralizando a acção dos agentes e contextos de socialização primária;

A constatação, sinalizada em trabalhos recentes, de que a escola, já não sendo capaz de cumprir cabalmente os mandatos que há muito lhe foram atribuídos, continua (paradoxalmente) a ser pressionada para assumir novos mandatos, à medida em que os problemas sociais aumentam, se diversificam e se complexificam;

A emergência de um sentimento anti-escola que se expressa, em alguns países, pela existência de um movimento de defesa do ensino em contexto familiar (home schooling), movimento este que é estimulado por discursos anti-estatistas que reclamam do fracasso da escola pública e que são promovidos por uma mescla de sectores religiosos fundamentalistas e segmentos neoliberais e neoconservadores desejosos de restaurar valores sociais e educacionais tradicionais (p.27)

São esses fatos reais ou ideologicamente construídos, que na concepção do referido autor podem explicar a não tão atual crise da educação escolar e a recente valorização dos campos da educação não formal. No entanto, é importante observar que, apesar desta constatação o autor refere que a valorização da educação não formal não pode ser atribuída somente à crise da escola.

Existem outros aspectos relacionados às próprias transformações e mudanças porque passou ou vem passando a sociedade da informação e do conhecimento, que contribuíram para o surgimento e a ampliação de novos espaços e práticas educativas como é o caso da educação não formal.

Para o autor o que importa considerar é que se é verdade que estes novos lugares educativos se originaram a partir de fenômenos que pouco ou nada têm a ver 
com a crise da escola, também é verdade que eles podem vir a acentuar e aprofundar a crise da mesma, sobretudo se controlados por interesses econômicos dominantes.

Por estas e outras razões, há que se refletir mais profundamente sobre os dilemas e desafios futuros que derivam do fato de o campo da educação não formal ser hoje disputado por muitos e diferentes interesses, e contraditórias racionalidades políticas e pedagógicas.

Por outro lado, o que deve ficar esclarecido é que o termo educação não formal não pressupõe a inexistência de uma formalidade e organização em virtude de não se realizar em espaços formais de ensino, a educação não formal caracteriza-se sim por ser uma maneira diferenciada de trabalhar com a educação paralelamente a escola, sendo uma de suas particularidades a busca pelo prazer da descoberta e do desafio na construção do conhecimento.

Por isso, independentemente da função e do lugar da educação não formal no quadro educativo mais global, isto é, seja ela entendida como alternativa, como complemento ou como suplemento, o enfoque na ação possibilita a reflexão e o debate em torno dos efeitos da educação não formal ao nível das aprendizagens significativas.

Assim, é possível entendê-la no plano dos processos e espaços de socialização, nos domínios das sociabilidades e dos estilos de vida, na educação familiar, nas trajetórias escolares e nos percursos relacionados com o mundo do trabalho, entre outras dimensões estruturantes dos diversos espaços em que se encontram os indivíduos.

No capítulo 3 apresento a metodologia da pesquisa, um capítulo dedicado a explicitar os caminhos que foram percorridos para o desenvolvimento da pesquisa, pois adotar uma metodologia significa escolher um caminho, um percurso global que será trilhado de acordo com as suas especificidades. O objetivo desse capítulo é por tanto não só contribuir para a evolução do conhecimento em relação à educação não formal, mas situar cada etapa do desenvolvimento da pesquisa. 


\section{CAPÍTULO 3 \\ METODOLOGIA DA PESQUISA}

Para o desenvolvimento de uma pesquisa científica é necessário traçar um caminho amplo, ou seja, um método para desenvolver o estudo. Pesquisar é um trabalho que envolve um planejamento cuidadoso, reflexões conceituais sólidas e alicerçadas em conhecimentos já existentes.

Por outro lado, é possível dizer que a pesquisa científica objetiva fundamentalmente contribuir para a evolução do conhecimento humano em todos os setores. Sendo que o seu sucesso dependerá além do procedimento seguido, do envolvimento com a pesquisa e da habilidade em escolher o caminho para atingir os objetivos da pesquisa.

Assim, para realizar essa pesquisa, foi necessário trilhar muitos caminhos, pois além da minha pouca vivência e experiência no campo da educação não formal, foi de fundamental importância as muitas leituras sobre o tema que contribuíram sem dúvida para uma maior aproximação com o universo da educação não formal.

\subsection{Caminhos da Pesquisa}

Durante o ano de 2008, ano da minha inserção nos espaços de educação não formal, pude perceber o quanto esse universo precisa de profissionais mais bem preparados, não só do ponto de vista da formação teórica, o que é imprescindível, mas do ponto de vista de uma prática pedagógica mais ampla. Ou seja, uma prática pedagógica que ofereça subsídios aos pedagogos para atuar em qualquer lugar que necessite de um trabalho pedagógico.

Essa preocupação parece fundamental, no sentido de entender a importância de se discutir sobre a atuação de pedagogos nos espaços de educação não formal, pois com as diversas transformações na sociedade e no mundo do trabalho, novas possibilidades de atuação para os profissionais de pedagogia vão surgindo. Porém, o 
que se percebe é que a sua prática pedagógica está cada vez mais fragilizada em virtude de uma formação ainda insuficiente para dar conta de todos esses universos educativos.

Neste sentido, num primeiro momento da pesquisa, a opção foi de problematizar os sentidos da educação não formal, sua constituição como campo de estudos, considerando as contribuições de autores que vem se destacando na discussão do tema.

Tal perspectiva sinalizou para uma discussão que considerou a importância de se pensar na atuação de pedagogos em espaços de educação não formal, requerendo um processo de investigação e análise do ponto de vista da trajetória formativa desses profissionais.

Alguns motivos remeteram a essa escolha: primeiro, porque se pressupõe que os profissionais que atuam ou que pretendem atuar, no campo da educação não formal necessitam do conhecimento das especificidades que permeiam esse universo e, segundo, porque essa atuação requer uma adequação de sua linguagem e da sua prática educativa ao contexto ao qual está inserido e a quem está voltado.

Mas como ter conhecimento dessas especificidades se a formação do pedagogo de maneira geral ainda está muito direcionada aos ambientes de educação formal? E é justamente, baseada nesse questionamento que levanto o problema da pesquisa, em que busco analisar e problematizar a trajetória formativa de pedagogos que atuam em espaços de educação não-formal.

Nessa perspectiva, a pesquisa se organizou no sentido de discutir sobre a atuação desses profissionais nos espaços de educação não formal, como forma não só de conhecer e problematizar a trajetória formativa dos mesmos, mas refletir sobre a importância de sua atuação nesses diversificados universos de atuação. Este problema será sustentado pelas seguintes questões norteadoras:

1) Qual a trajetória formativa dos profissionais de pedagogia que trabalham nos espaços de educação não formal?

2) De que experiências anteriores esses profissionais se valem para embasarem suas práticas? 
3) De que forma esses profissionais buscam e garantem sua formação?

4) Quais as principais dificuldades encontradas na prática pedagógica no contexto da educação não formal?

5) Os cursos de graduação em pedagogia têm contribuído para a preparação desses profissionais que atuam na educação não formal?

Segundo Chizzotti (1995), "A pesquisa investiga o mundo em que o homem vive e o próprio homem" (p.11). Contudo, a pesquisa só existe com apoio de procedimentos metodológicos adequados, que permitam a aproximação ao objeto de estudo.

Com base nessa concepção, é possível dizer que se trata de uma pesquisa de cunho qualitativo realizada em alguns momentos distintos. No primeiro momento, desenvolvo a pesquisa bibliográfica sobre o campo epistemológico do pedagogo, no que se refere à construção e à conquista de espaços no campo da educação não formal no Brasil.

De acordo Gil (2002):

"[...] a pesquisa bibliográfica é desenvolvida com base em material já elaborado, constituído principalmente de livros e artigos científicos. A principal vantagem da pesquisa bibliográfica está no fato de permitir ao investigador a cobertura de uma gama de fenômenos muito mais ampla do que aquela que poderia pesquisar diretamente" (p. 45).

Sua finalidade é colocar o pesquisador em contato com o que já se produziu e registrou a respeito do tema de pesquisa. Tais vantagens revelam o compromisso da qualidade da pesquisa. Assim, além de permitir o levantamento das pesquisas referentes ao tema estudado, a pesquisa bibliográfica permite ainda o aprofundamento teórico, contribuindo para o desenvolvimento de um referencial crítico-dialético.

Posteriormente, desenvolvo a pesquisa de campo com a utilização de entrevistas semiestruturadas com alguns pedagogos que trabalham numa Associação Civil, sem fins lucrativos, que detém a titulação também de Organização da Sociedade 
Civil de Interesse Público (OSCIP), de forma a compor um perfil desses profissionais inseridos em tal contexto.

Para Gonçalves (2001):

[...] a pesquisa de campo é o tipo de pesquisa que pretende buscar a informação diretamente com a população pesquisada. Ela exige do pesquisador um encontro mais direto. Nesse caso, o pesquisador precisa ir ao espaço onde o fenômeno ocorre, ou ocorreu e reunir um conjunto de informações a serem documentadas [...] (p. 67).

O processo de escolha para desenvolver a pesquisa de campo nessa instituição se deu por meio de uma pesquisa na internet. A partir dessa pesquisa, pelo site da instituição, pude conhecer um pouco do trabalho que eles desenvolvem no campo da educação não formal. Então, o primeiro passo foi enviar um e-mail para o departamento de comunicação da mesma para saber sobre a possibilidade da minha pesquisa de campo estar sendo desenvolvida lá.

Para minha surpresa, eles se mostraram bem receptivos com a proposta e encaminharam o meu e-mail ao presidente da instituição, que de pronto gostou da ideia e concordou com o desenvolvimento da pesquisa. Para uma melhor aproximação com a instituição marquei com o presidente uma visita, para além de conhecer de perto a entidade e os profissionais, eu pudesse levar uma cópia do meu projeto.

Depois de esclarecer alguns pontos do projeto, falei da necessidade da carta de consentimento da instituição para que eu pudesse desenvolver a pesquisa e também dos profissionais que eu precisaria entrevistar. Ele achou muito interessante e importante a temática da minha pesquisa e disse que estava a disposição para o que fosse preciso.

De posse do documento dando consentimento para a realização da pesquisa, entrei em contato novamente com a instituição para definir os profissionais e a data em que seriam entrevistados. Foi definido um total de 4 sujeitos, sendo três pedagogas e uma gestora de projetos. Todo o contato com os sujeitos da pesquisa foram feitos por intermédio da própria instituição que com muita seriedade se encarregou de convidá-los repassando inclusive a minha carta convite. 
Para a realização das entrevistas foi desenvolvido um roteiro de entrevistas semiestruturadas, o qual está como anexo no trabalho. Esse roteiro contém duas partes, a primeira para definir o perfil dos entrevistados e a segunda se constitui no roteiro de entrevistas propriamente dito.

A organização do roteiro foi pensada no sentido de dar conta das questões norteadoras que sustentam o problema da pesquisa o que significou na opção por dividi-lo em cinco temas ou categorias, todas dentro do contexto da educação não formal. A primeira, em relação à trajetória formativa do pedagogo; a segunda, em relação à atuação do pedagogo; a terceira, em relação ao perfil profissional do pedagogo; a quarta, em relação às dificuldades encontradas na prática pedagógica e, a última em relação à formação continuada.

Todos os anexos inseridos no presente trabalho contêm fielmente o conteúdo do que foi perguntado nas entrevistas, que foram realizadas na sede da própria instituição que está situada na região central de São Paulo. E a partir da leitura e análise de conteúdo das entrevistas procurou-se evidenciar o perfil profissional de educadores inseridos nesse contexto.

$\mathrm{Na}$ busca por uma instituição que se enquadrasse na realidade da minha pesquisa, o critério para a escolha da referida instituição se deu especialmente por ser um espaço de prática real da educação não formal. Um espaço que tem como pilares, o trabalho e a educação, onde são desenvolvidos diversificados projetos além de ser palco também para atuação do principal sujeito da pesquisa o pedagogo.

Por tanto, antes de aprofundar a discussão em relação ao processo de coleta de dados, faço uma breve descrição da instituição de forma a situar e caracterizar a mesma em relação ao público que atende, aos projetos sociais e as práticas de educação não formal que desenvolvem no seu trabalho diário.

\section{Caracterizando a Instituição}

A instituição em que se organizou a pesquisa de campo, espaço de trabalho e de atuação dos sujeitos da pesquisa está constituída desde o ano de 2004. Foi criada por profissionais que aproveitaram suas diferentes experiências para realizar projetos 
sociais que, efetivamente, resultassem em alguma transformação na vida de seus beneficiários, especialmente no que diz respeito à inserção produtiva e social.

Atua na área da educação e tem por missão promover a sustentabilidade, a cidadania, a inclusão social e a geração de trabalho e renda por meio da educação. A instituição atende prioritariamente, jovens e adultos em situação de vulnerabilidade social. Em seus 7 anos de existência, a entidade atendeu cerca de 107.000 pessoas e, atualmente, encontram-se em execução 6 projetos que qualificação que beneficiam cerca de 20.000 educandos.

Tem como foco o trabalho com Projetos Sociais como o Projovem Urbano, possui uma sede na região central da cidade de São Paulo, uma filial em Florianópolis e uma unidade na cidade de Jundiaí. Tem como missão promover a sustentabilidade, a cidadania, a inclusão social e a geração de trabalho e renda por meio da educação.

Além das unidades operacionais onde desenvolve suas atividades, é uma instituição que se caracteriza pela forte desenvolvimento e implantação de projetos. Sua atuação possui as seguintes linhas de ação: educação e qualificação profissional com mais de 70 tipos de cursos profissionalizantes, educação ambiental com 0 desenvolvimento de Ciclos de Eficiência Energética, em conformidade com a ANEEL para as distribuidoras de energia e educação corporativa com o desenvolvimento de Cursos in-company e estruturação de unidades corporativas em parceria com centros de excelência em educação.

A instituição conta com mais de 80 projetos voltados a geração de emprego e renda, cidadania, direitos humanos, ressocialização e na área ambiental. Atualmente a instituição possui os seguintes projetos ativos: Projovem Urbano (Mato Grosso); Projovem Urbano (Santa Catarina); Casa da beleza com o Curso de Qualificação socioprofissional em Estética e Beleza (Município de Várzea Paulista); Gestão Pedagógica Laboratório de Desenvolvimento Social e Digital ( Município de Várzea Paulista); PRONASCI (Campinas); Ação Cidadão, Estação Juventude, Núcleos de Assistência Social e Grupo Convivência (Município de Campo Limpo Paulista); Fundação Casa (Unidades de Internação da Região Metropolitana de São Paulo); Projeto VONPAR (Município de Palhoça - SC); Projovem Trabalhador ( Município de Embu - SP); Projovem Trabalhador ( Município de Taboão da Serra - SP); Projeto 
Horizontes Trilhas ( Estado de São Paulo); Projeto Sentinela ( Florianópolis); Projeto CADE - Centro de Apoio ao Desenvolvimento e ao Empreendedorismo ( Estado de São Paulo).

\subsection{Processo de Coleta dos dados}

O processo de coleta de dados se deu por meio de entrevistas semiestruturadas com três pedagogas e uma gestora de projetos que foram registradas com a utilização de um MP4 e/ou gravador e transcritas conforme consentimentos das mesmas.

Foram realizados alguns contatos com a instituição e a mesma se encarregou de fazer os contatos com as pedagogas e com a gestora de projetos para o agendamento das entrevistas. Todas optaram por realizar as entrevistas na própria sede da instituição de acordo com sua disponibilidade de horário.

Para a realização dessas entrevistas foi elaborado um roteiro de entrevistas para as pedagogas e outro roteiro para a gestora de projetos. O roteiro de entrevistas das pedagogas está dividido em duas partes, a primeira contém dados para definir o perfil das entrevistadas e segunda parte contém quatorze questões referentes ao contexto da educação não formal.

Já o roteiro de entrevistas para a gestora de projetos está dividido em três partes, a primeira parte para definir o perfil da entrevistada, a segunda para conhecer o perfil da instituição e a terceira parte para saber quais as concepções que se tem enquanto gestor de projetos da instituição sobre atuação de pedagogos nos espaços de educação não formal.

De acordo com Minayo (2000):

A entrevista é o procedimento mais usual no trabalho de campo. Através dela, o pesquisador busca obter informes contidos na fala dos atores. Ela não significa uma conversa despretensiosa e neutra, uma vez que se insere como meio de coleta dos fatos relatados pelos atores, enquanto sujeitos - objetos da pesquisa que vivenciam uma determinada realidade que está sendo focalizada (p.57). 
Assim a utilização de entrevistas é relevante por provocar ricas contribuições dos sujeitos, pois ela estabelece uma interação com o entrevistado, possibilitando o levantamento de dados e a seleção dos aspectos mais relevantes de um problema de pesquisa.

As entrevistas expressam, segundo Chizzotti (1995), "as representações subjetivas dos participantes, possibilitando intervenções do pesquisador em sua realidade ou ações transformadoras mediante questões problemáticas. (p.90).

As entrevistas foram realizadas na data agendada com os sujeitos da pesquisa (pedagogas e a gestora de projetos) e ocorreu de forma tranquila e interativa. Todas as participantes foram muito atenciosas respondendo a todas as questões do roteiro de entrevistas e as foram transcritas para a devida análise dos dados.

\subsection{Sujeitos da pesquisa}

Foram selecionadas como participantes da pesquisa 3 pedagogas e 1 gestora de projetos. As pedagogas por ser foco realmente do objeto de estudo da referida pesquisa e a gestora de projetos por ser um importante elemento não só no processo de caracterização da instituição, isto é, que tipo de trabalho desenvolvem, qual o público alvo que atendem, mas qual a concepção que a instituição e ela como gestora de projetos tem em relação a atuação de pedagogos nos espaços de educação não formal.

Os sujeitos da pesquisa foram, então, identificados por nomes fictícios. Sujeito P1 ( Pedagoga 1), P2 ( Pedagoga 2), P3 ( Pedagoga 3), G4 ( Gestora de Projetos). O quadro abaixo mostra dados sobre o perfil dos sujeitos que compuseram a amostra da pesquisa como o sexo, a idade, a formação, o cargo atual que ocupa na instituição e o tempo de atuação na educação não formal. 
Quadro perfil sujeitos da pesquisa:

\begin{tabular}{|c|c|c|c|c|c|}
\hline SUJEITOS & SEXO & IDADE & FORMAÇÃO & $\begin{array}{l}\text { CARGO } \\
\text { ATUAL NA } \\
\text { INSTITUIÇÃOO }\end{array}$ & $\begin{array}{l}\text { TEMPO } \\
\text { ATUAÇÃO NA } \\
\text { EDUCAÇÃO } \\
\text { NÃO FORMAL }\end{array}$ \\
\hline $\mathrm{P} 1$ & $F$ & 52 & Pedagogia & $\begin{array}{l}\text { Instrutora de } \\
\text { Cursos Livres }\end{array}$ & 20 anos \\
\hline $\mathrm{P} 2$ & $\mathrm{~F}$ & 26 & Pedagogia & $\begin{array}{c}\text { Coordenadora } \\
\text { pedagógica }\end{array}$ & 5 anos \\
\hline P3 & $F$ & 33 & Pedagogia & Educadora & 2 meses \\
\hline G4 & $F$ & 37 & $\begin{array}{c}\text { Organização e } \\
\text { Gestão de } \\
\text { Eventos }\end{array}$ & $\begin{array}{c}\text { Gestora de } \\
\text { projetos }\end{array}$ & 7 anos \\
\hline
\end{tabular}

Entre os quatro sujeitos pesquisados, $100 \%$ deles são do sexo feminino, entre a faixa etária que varia de 26 a 52 anos, 3 sujeitos com formação em Pedagogia e 1 com formação em Organização de Eventos, possuem cargos diferenciados na instituição e com tempo de atuação na educação não formal que varia de 7 a 20 anos. 


\section{CAPÍTULO 4}

\section{RESULTADOS DA PESQUISA}

A análise e a interpretação dos dados de uma pesquisa é o processo de formação de sentido que está além dos dados, e esta formação se dá consolidando, limitando e interpretando o que os sujeitos disseram e o que o pesquisador viu e leu, isto é, o processo de formação de significado. Estes significados ou entendimentos constituem a constatação de um estudo.

Franco (2008, p.13) afirma que "o significado de um objeto pode ser absorvido, compreendido e generalizado a partir de suas características definidoras e pelo seu corpus de significação".

Os processos de análise e interpretação variam significativamente em função dos diferentes delineamentos de pesquisa e, no caso específico da referida pesquisa, a opção pela análise de conteúdo - como discutido mais adiante, deveu-se, especialmente, à importância que essa metodologia tem para a compreensão dos demais sentidos expressados.

\subsection{Análise e interpretação dos dados}

Para a organização dos dados coletados por meio das entrevistas, foi feita a opção pela Análise de Conteúdo, que permite ao pesquisador fazer recortes importantes obtidos no universo da pesquisa de campo realizada.

Franco (2008, p. 12) afirma que "o ponto de partida da Análise de conteúdo é a mensagem, seja ela verbal (oral ou escrita), gestual, silenciosa, figurativa, documental ou diretamente provocada".

Em outras palavras, o que está escrito ou falado de forma simbólica sempre será o ponto de partida para a identificação do conteúdo, seja ele explícito ou latente, isto é, a mensagem expressa necessariamente um significado e um sentido articulada ao contexto de quem a produziu. 
Para Chizzotti (1995):

Análise de Conteúdo é um método de tratamento e análise de informações, colhidas por meio de técnicas de coleta de dados, consubstanciadas em um documento. O objetivo da análise de conteúdo é compreender criticamente o sentido das comunicações, seu conteúdo manifesto ou latente, as significações explícitas ou ocultas (p.98).

Por meio da análise de conteúdo procuramos, portanto, estudar e analisar o material qualitativo buscando melhor compreensão das comunicações ou discursos, aprofundando os aspectos mais relevantes em suas características gramaticais e ideológicas (BARROS e LEHFEL, 2000).

Entre as várias possibilidades para a análise e a interpretação dos dados, em particular para a presente pesquisa, optei para o tratamento e discussão dos dados a técnica de análise temática, que pode ser considerada como a mais útil unidade de registro em se tratando de análise de conteúdo, indispensável em vários estudos sobre propaganda, representações sociais opiniões, expectativas, valores, conceitos, atitudes, crenças etc.

A uma afirmação sobre determinado assunto, normalmente associa-se o tema, permitindo grande quantidade de relações, podendo ser expresso pela comunicação escrita, expresso por palavras, frases ou resumos. Quando realizamos a investigação do tema, podemos descobrir os núcleos de sentido, em acordo com seu aparecimento ou repetição no texto, ou seja, a presença de determinados temas denota os valores de referência e os modelos de comportamento presentes no discurso. (MINAYO, 2004).

É válido ressaltar que apesar do tema ser uma unidade de análise fundamental em determinadas pesquisas, por permitir uma interpretação com diferentes significados, é necessário analisar e interpretar o conteúdo de cada resposta em seu sentido individual e único.

Definida as unidades de análise é necessário definir as categorias e seus respectivos indicadores que são num primeiro momento determinados em função da busca a uma resposta específica do pesquisador. 
De acordo com Franco (2008):

As categorias vão sendo criadas, à medida que surgem nas respostas, para depois serem interpretadas à luz das teorias explicativas. Em outras palavras, o conteúdo que emerge do discurso, é comparado com algum tipo de teoria. Infere-se, pois, das diferentes "falas", diferentes concepções de mundo, de sociedade, de escola, de indivíduo etc. (p. 54)

Dessa forma, no sentido de analisar e interpretar o conteúdo da resposta de cada sujeito da pesquisa, a opção foi pela organização por meio de quadros, apresentando as questões e os fragmentos das respostas obtidas dos sujeitos de modo a auxiliar, como indicadores para uma efetiva análise e interpretação dos dados.

Foram agrupadas cinco temáticas que serviram para categorizar o conteúdo e análise das entrevistas dos sujeitos. Assim, neste capítulo, faço a apresentação dos dados obtidos considerando segmentos das respostas das pedagogas, extraídas das entrevistas, fazendo um paralelo com a percepção da gestora, em relação a essas mesmas temáticas, em sua entrevista.

Esclareço que não fiz uso das respostas na íntegra, mas trago o conteúdo das respostas que, em minha leitura, se revelaram significativas para a resposta de cada pergunta em questão. Assim, o conteúdo das entrevistas, em sua totalidade, encontrase nos Anexos 1, 2, 3 e 4.

Tema 1: Trajetória formativa do pedagogo que atua no contexto da educação não formal

Quadro 1 - Respostas dos sujeitos à questão: Como aconteceu a decisão ou a oportunidade de trabalhar com a educação não formal?

\begin{tabular}{|l|l|}
\hline SUJEITOS & \multicolumn{1}{|c|}{ RESPOSTAS } \\
\hline P1 & $\begin{array}{l}\text { Primeiro, eu não sabia nem o que era educação não formal. Trabalhei na } \\
\text { área financeira por vários anos. Depois de um tempo, fui trabalhar numa } \\
\text { creche e foi aí que começou a minha inserção no universo da educação } \\
\text { não formal. }\end{array}$ \\
\hline
\end{tabular}




\begin{tabular}{|l|l|}
\hline P2 & $\begin{array}{l}\text { A minha inserção no universo da educação não formal foi meio ao acaso, } \\
\text { foi uma oportunidade que surgiu e eu não larguei mais. }\end{array}$ \\
\hline P3 & $\begin{array}{l}\text { Não foi uma decisão e sim uma oportunidade que surgiu, e eu como } \\
\text { pedagoga recém-formada com muita vontade de trabalhar aceitei, o que } \\
\text { para mim está sendo um desafio do qual eu estou muito orgulhosa. }\end{array}$ \\
\hline
\end{tabular}

\begin{tabular}{|l|l|}
\hline G4 & $\begin{array}{l}\text { Em sua opinião o que faz o pedagogo na sociedade atual decidir ou } \\
\text { ter a oportunidade de trabalhar com a educação não formal? } \\
\text { A vontade de exercer práticas diferentes de educação, que às vezes não } \\
\text { são possíveis em algumas instituições de ensino formal. }\end{array}$ \\
\hline
\end{tabular}

Em relação ao tema 1 a análise das entrevistas revelou que, para as pedagogas P1, P2 e P3, a inserção no universo da educação não formal não aconteceu de forma planejada, mas como uma oportunidade de trabalho que surgiu em determinada fase da atuação profissional de cada uma.

Para a gestora G4, o que leva o pedagogo a decidir ou ter a oportunidade de trabalhar com a educação não formal está diretamente relacionado à vontade de exercer práticas diferentes de educação que, na grande maioria das vezes, não é possível nas instituições de ensino formal. 
Quadro 2 - Respostas dos sujeitos à questão: Você tem alguma formação específica para trabalhar no contexto da educação não formal? Qual?

\begin{tabular}{|l|l|}
\hline SUJEITOS & \multicolumn{1}{c|}{ RESPOSTAS } \\
\hline P1 & $\begin{array}{l}\text { Bom, além da pedagogia eu tenho o curso na área de Processamento de } \\
\text { Alimentos pelo SENAI, essa formação técnica me ajudou e me ajuda } \\
\text { muito a compreender e a sugerir algumas coisas dentro do próprio curso } \\
\text { que ministro. A formação em pedagogia me ajuda a adequar e repassar } \\
\text { esse conhecimento mais específico de uma forma mais didática. }\end{array}$ \\
\hline P2 & $\begin{array}{l}\text { A minha formação em recursos humanos e a formação em pedagogia me } \\
\text { auxilia muito, porque a gente trabalha com qualificação profissional. Por } \\
\text { enquanto eu não tenho especialização, acabei de iniciar uma que é para } \\
\text { tecnologia da educação. }\end{array}$ \\
\hline P3 & \begin{tabular}{l} 
Não, sou formada apenas em pedagogia. \\
\hline
\end{tabular} \\
\hline
\end{tabular}

\begin{tabular}{|l|l|}
\hline G4 & $\begin{array}{l}\text { Em sua opinião o pedagogo precisa de uma formação específica } \\
\text { para trabalhar no contexto da educação não formal? Qual? } \\
\text { Penso que as técnicas aprendidas na formação do pedagogo são } \\
\text { suficientes. Mas para que elas funcionem é necessária a vontade de fazer } \\
\text { da educação uma atividade prazerosa que contribua, necessariamente, } \\
\text { para a autonomia do educando. }\end{array}$ \\
\hline
\end{tabular}


Dentro ainda do tema 1, o conteúdo da análise das entrevistas evidenciou que as pedagogas P1, P2 e P3 não possuem formação específica para trabalhar no contexto da educação não formal. Para a gestora G4, o pedagogo não precisa de uma formação específica; para ela, as técnicas aprendidas, ainda na formação, são suficientes para dar conta desse contexto.

Quadro 3 - De que forma você buscou ou garantiu a sua formação para atuar em espaços de educação não formal?

\begin{tabular}{|l|l|}
\hline SUJEITOS & \multicolumn{1}{|c|}{ RESPOSTAS } \\
\hline P1 & $\begin{array}{l}\text { Na verdade, posso dizer que não foi uma coisa programada. Fiz o curso } \\
\text { de processamento de alimentos porque sempre gostei muito dessa área, } \\
\text { mas nunca pensei que fosse me ajudar tanto na minha atuação nos } \\
\text { espaços e educação não-formal como aqui na Associação. }\end{array}$ \\
\hline P2 & $\begin{array}{l}\text { Na verdade, eu não busquei tudo aconteceu meio ao acaso. Com a } \\
\text { formação em pedagogia e com minha inserção nesse contexto da } \\
\text { educação não formal estou buscando algumas especializações e tentando } \\
\text { cada vez mais me adequar a esse universo. }\end{array}$ \\
\hline P3 & $\begin{array}{l}\text { Eu diria que ainda estou buscando. A instituição para qual eu trabalho, } \\
\text { oferece aos seus educadores formação contínua, por meio de cursos, } \\
\text { palestras, treinamentos, enfim, só não se capacita quem não quer } \\
\text { mesmo. }\end{array}$ \\
\hline
\end{tabular}




\begin{tabular}{|l|l|}
\hline G4 & $\begin{array}{l}\text { Em sua opinião o pedagogo deve buscar e garantir a sua formação } \\
\text { para atuar em espaços de educação não formal? } \\
\text { A formação específica na área da educação é sempre bem vinda. }\end{array}$ \\
\hline
\end{tabular}

Seguindo a análise em relação ao tema 1, as respostas obtidas tanto das pedagogas $\mathrm{P} 1, \mathrm{P} 2$ e $\mathrm{P} 3$ revelaram que não foi um processo programado por isso não buscaram logo formação para atuar em espaços de educação não formal, mas que agora conscientes de sua inserção nesses espaços estão em busca de uma formação mais direcionada a esse universo. Já para a gestora G4 a formação específica na área é sempre bem vinda.

Quadro 4 - De que experiências anteriores você se baseia para embasar a sua prática atual?

\begin{tabular}{|l|l|}
\hline SUJEITOS & \multicolumn{1}{|c|}{ RESPOSTAS } \\
\hline P1 & $\begin{array}{l}\text { Experiências de trabalhos diferentes, experiências de vida, da prática } \\
\text { diária mesmo ajudam o embasamento da minha prática atual. }\end{array}$ \\
\hline $\mathbf{P 2}$ & $\begin{array}{l}\text { Baseio-me nas experiências de vida, além das práticas pedagógicas de } \\
\text { ensino. }\end{array}$ \\
\hline $\mathbf{P 3}$ & $\begin{array}{l}\text { Na verdade eu não tenho experiências anteriores, mas procuro estar } \\
\text { sempre aberta para novos conhecimentos e a experiência virá com o } \\
\text { tempo, com a prática diária eu acredito. }\end{array}$ \\
\hline
\end{tabular}




\begin{tabular}{|l|l|}
\hline G4 & $\begin{array}{l}\text { Em sua opinião as experiências que o pedagogo traz são } \\
\text { importantes para embasar a sua prática no contexto da educação } \\
\text { não formal? } \\
\text { Sim, as experiências sempre contribuem para o desempenho de sua } \\
\text { função. }\end{array}$ \\
\hline
\end{tabular}

Dando continuidade a linha de análise do tema 1, as respostas das entrevistas revelaram que, para as pedagogas $\mathrm{P} 1$ e $\mathrm{P} 2$, as experiências de vida e da própria prática diária são fundamentais para dar embasamento a sua prática atual. A pedagoga P3 revelou que tem pouca experiência, mas também acredita na experiência da prática diária como alicerce para sua prática atual. Para a gestora G4 as experiências de uma forma geral sempre contribuem para um melhor desempenho profissional.

Quadro 5 - Em sua opinião os cursos de graduação em pedagogia têm contribuído para a preparação dos profissionais de pedagogia que atuam na educação não formal? Se sim, de que forma? Se não, por quê?

\begin{tabular}{|l|l|}
\hline SUJEITOS & \multicolumn{1}{|c|}{ RESPOSTAS } \\
\hline P1 & $\begin{array}{l}\text { Acredito que não, porque é mais teoria do que prática. O que contribui } \\
\text { mesmo são as experiências que você vai encaixando com essas teorias. } \\
\text { É o que você vai aprendendo durante o processo, isto é, é se inserir } \\
\text { mesmo nesse universo e colocar a mão na massa. }\end{array}$ \\
\hline P2 & $\begin{array}{l}\text { Eu acredito que não contribui. Como o curso de pedagogia não me deu } \\
\text { preparação, o que tento fazer é adequar o conhecimento e a teoria a } \\
\text { nossa realidade aqui. }\end{array}$ \\
\hline
\end{tabular}




\begin{tabular}{|l|l|}
\hline P3 & $\begin{array}{l}\text { Sim. O profissional graduado em pedagogia tem uma visão mais ampla da } \\
\text { educação em geral. Acredito que o pedagogo consegue organizar as } \\
\text { formas de transmissão de conhecimento de maneira mais clara, focando } \\
\text { sempre o aprendizado. }\end{array}$ \\
\hline
\end{tabular}

\begin{tabular}{|l|l|}
\hline G4 & $\begin{array}{l}\text { Em sua opinião os cursos de graduação em pedagogia devem } \\
\text { contribuir para a preparação dos profissionais de pedagogia que } \\
\text { atuam na educação não formal: } \\
\text { Penso que já contribuem. Mas sempre há espaço para fortalecer essa } \\
\text { atividade. }\end{array}$ \\
\hline
\end{tabular}

Seguindo a análise do tema 1 , as entrevistas revelaram que tanto para a pedagoga $\mathrm{P} 1$, como para a $\mathrm{P} 2$ os cursos de graduação em pedagogia não têm contribuído para a preparação dos profissionais de pedagogia que atuam na educação não-formal.

Já a pedagoga P3 acredita que tem contribuído sim, pois para ela o profissional graduado em pedagogia tem uma visão mais ampla da educação em geral. A gestora G4 acredita que os cursos de graduação em pedagogia também contribuem de forma positiva para a formação dos pedagogos que atuam na educação não formal, mas ressalta a importância de fortalecer esse processo. 
Quadro 6 - Você acha importante fortalecer a discussão com a Universidade da importância da atuação de pedagogos em espaços de educação não formal? Se sim, de que forma? Se não, por quê?

\begin{tabular}{|l|l|}
\hline SUJEITOS & \multicolumn{1}{|c|}{ RESPOSTAS } \\
\hline P1 & $\begin{array}{l}\text { Acho importante sim. Esse fortalecimento poderia acontecer por meio de } \\
\text { parcerias com o Terceiro setor, propiciando ao aluno a sua inserção para } \\
\text { ele ver na prática como é o trabalho nesse universo da educação não } \\
\text { formal. }\end{array}$ \\
\hline P2 & $\begin{array}{l}\text { Eu acho importante sim. Seria primordial que a universidade repensasse a } \\
\text { questão do currículo, pois eu acho difícil alguém que se forme em } \\
\text { pedagogia, se ela nunca atuou no Terceiro setor ou com essa modalidade } \\
\text { de educação não formal, vai acabar sendo direcionado a trabalhar na } \\
\text { educação infantil ou no ensino fundamental. }\end{array}$ \\
\hline P3 & $\begin{array}{l}\text { Sim. É importante que haja discussão com a Universidade, pois com essa } \\
\text { nova perspectiva cada vez mais pedagogos estão inseridos na educação } \\
\text { não formal. }\end{array}$ \\
\hline
\end{tabular}

\begin{tabular}{|l|l|}
\hline G4 & $\begin{array}{l}\text { Em sua opinião é importante fortalecer a discussão com a } \\
\text { Universidade da importância da atuação de pedagogos em espaços } \\
\text { de educação não formal? } \\
\text { Sim. Mostrando esse setor como uma opção de atuação e o que é } \\
\text { necessário para trabalhar nele. }\end{array}$ \\
\hline
\end{tabular}


Concluindo a análise do conteúdo das entrevistas do tema 1, tanto as pedagogas P1, P2, P3 e a gestora G4 revelaram que é importante, sim, fortalecer a discussão com a Universidade sobre a inserção e a atuação de pedagogos em espaços de educação não formal. Para a pedagoga P1 esse fortalecimento poderia ocorrer por meio de parcerias com o Terceiro Setor.

Para a pedagoga P2 seria primordial que a universidade repensasse a questão do currículo, já a pedagoga P3 acredita que esse fortalecimento deve acontecer por meio de discussão com a universidade. A gestora G4 acredita que apresentar o setor como uma opção de atuação e em decorrência o que é necessário para trabalhar nele seria uma boa forma de fortalecer essa discussão.

\section{Tema 2: Atuação do pedagogo no contexto da educação não formal}

Quadro 7 - Respostas dos sujeitos à questão: O que é para você trabalhar com Educação não formal?

\begin{tabular}{|l|l|}
\hline SUJEITOS & \multicolumn{1}{|c|}{ RESPOSTAS } \\
\hline P1 & $\begin{array}{l}\text { Trabalhar com a educação não formal significa liberdade. Acho que você } \\
\text { tem uma liberdade maior para desenvolver seu trabalho e isso eu acho } \\
\text { positivo. }\end{array}$ \\
\hline P2 & $\begin{array}{l}\text { Para mim é um dilema. A gente desenvolve o plano de curso, plano de } \\
\text { aula, trabalha instrumentalizado, mas ao mesmo tempo nós não temos na } \\
\text { Lei de Diretrizes e Bases da Educação um direcionamento que diga, olha } \\
\text { você tem que ir por aqui ou por ali, ou então isso tem que ser cumprido na } \\
\text { sua atuação. }\end{array}$ \\
\hline P3 & $\begin{array}{l}\text { Trabalhar com a educação não formal está sendo um grande } \\
\text { aprendizado, são experiências que vou levar para o resto da minha vida e } \\
\text { com certeza para outras oportunidades de trabalho e de atuação. }\end{array}$ \\
\hline
\end{tabular}




\begin{tabular}{|l|l|}
\hline G4 & $\begin{array}{l}\text { Em sua opinião o que significa para você trabalhar com Educação } \\
\text { não formal? } \\
\text { Enfrentar desafios e ser criativo para tornar o aprendizado prazeroso. }\end{array}$ \\
\hline
\end{tabular}

Em relação à análise de conteúdo do tema 2, as respostas das entrevistas revelaram-se bastante distintas. Para a pedagoga P1 trabalhar com educação não formal significa liberdade para desenvolver seu trabalho, a pedagoga P2 revela que trabalhar com educação não formal é um dilema, pois não há um direcionamento na Lei de Diretrizes e Bases da Educação que diga o que deve ser cumprido. Para a pedagoga P3 trabalhar com educação não formal significa um grande aprendizado. A gestora G4 acredita que trabalhar com educação não formal é enfrentar desafios e ser criativo para tornar o aprendizado prazeroso.

Quadro 8 - Respostas dos sujeitos à questão: Em sua opinião, que conhecimentos são fundamentais para desenvolver um trabalho pedagógico no campo da educação não formal?

\begin{tabular}{|l|l|}
\hline SUJEITOS & \multicolumn{1}{|c|}{ RESPOSTAS } \\
\hline P1 & $\begin{array}{l}\text { O fundamental além de você ter o domínio do conteúdo é utilizar } \\
\text { instrumentos de trabalho como a didática, principalmente quando se } \\
\text { trabalha com a formação de educadores nessa área. }\end{array}$ \\
\hline P2 & $\begin{array}{l}\text { Eu acredito que primeiro tem que saber o que é a educação e conhecer e } \\
\text { entender qual é o seu papel nesse universo, ter algumas práticas, noções } \\
\text { de metodologias, de didática para poder trabalhar com esse aluno. }\end{array}$ \\
\hline P3 & $\begin{array}{l}\text { Acredito que os conhecimentos fundamentais são flexibilidade, motivação } \\
\text { e principalmente gostar daquilo que faz. }\end{array}$ \\
\hline
\end{tabular}




\begin{tabular}{|l|l|}
\hline G4 & $\begin{array}{l}\text { Em sua opinião que conhecimentos são fundamentais para que o } \\
\text { pedagogo possa desenvolver um trabalho pedagógico no campo da } \\
\text { educação não formal? } \\
\text { Conhecer as técnicas e didáticas de ensino é sempre importante, além da } \\
\text { realidade do educando. }\end{array}$ \\
\end{tabular}

Seguindo a linha de análise do tema 2, as pedagogas P1 e P2 revelam opiniões convergentes, pois acreditam que além de outros conhecimentos a didática é fundamental para desenvolver um bom trabalho pedagógico no campo da educação não formal. A pedagoga P3 não cita o papel da didática nesse processo, mas ressalta a importância da flexibilidade, da motivação e de gostar do que se faz. A gestora G4 também tem opinião convergente as pedagogas $\mathrm{P} 1$ e P2, pois também acredita no papel da didática como importante instrumento no desenvolvimento de um bom trabalho pedagógico no campo da educação não formal.

Tema 3: Perfil profissional do pedagogo no contexto da educação não formal Quadro 9 - Respostas dos sujeitos à questão: Existe ou não um perfil necessário para que o pedagogo desenvolva um trabalho educativo em espaços de educação não formal? Se sim qual seria esse perfil?

\begin{tabular}{|l|l|}
\hline SUJEITOS & \multicolumn{1}{|c|}{ RESPOSTAS } \\
\hline P1 & $\begin{array}{l}\text { Eu acredito que existe sim um perfil. É preciso em primeiro lugar gostar de } \\
\text { trabalhar com gente, porque você vai estar formando pessoas, seja em } \\
\text { qual área for. Em segundo lugar é preciso saber ouvir, pois independente } \\
\text { do curso, o aluno ou educando traz um conhecimento e uma cultura e isso } \\
\text { tem que ser respeitado. }\end{array}$ \\
\hline
\end{tabular}




\begin{tabular}{|l|l|}
\hline P2 & $\begin{array}{l}\text { Eu acho que depende. Na verdade, esse perfil está mais relacionado com } \\
\text { o que a instituição desenvolve, porque é aí que você tem que se adequar. }\end{array}$ \\
\hline P3 & $\begin{array}{l}\text { Um perfil não, mas para que haja o desenvolvimento de um trabalho } \\
\text { efetivo e de qualidade é fundamental que o profissional goste daquilo que } \\
\text { faz, e que principalmente esteja aberto para buscar novos conhecimentos. }\end{array}$ \\
\hline
\end{tabular}

\begin{tabular}{|l|l|}
\hline G4 & $\begin{array}{l}\text { Em sua opinião existe ou não um perfil necessário para que o } \\
\text { pedagogo desenvolva um trabalho educativo em espaços de } \\
\text { educação não formal? Se sim qual seria esse perfil? } \\
\text { Penso que a consciência de que o educando buscou uma formação, por } \\
\text { livre vontade, e de que é esse processo é fundamental a todo o } \\
\text { profissional que pretende atuar em espaços de educação não formal. }\end{array}$ \\
\hline
\end{tabular}

A análise de conteúdo das entrevistas relacionadas ao tema 3 revelou distinção nas respostas de todos os sujeitos. A pedagoga P1 acredita que existe sim um perfil para que o pedagogo desenvolva um trabalho educativo em espaços de educação não formal. A pedagoga P2 diz que depende, pois esse perfil está mais relacionado com o que a instituição desenvolve e por tanto a pessoa deve se adequar a esse contexto.

Já a pedagoga P3 acredita que não existe um perfil, pois basta que o profissional goste daquilo que faz, e que principalmente esteja aberto para buscar novos conhecimentos. Para a gestora G4 o pedagogo que quer atuar em espaços de educação não formal deve ter a consciência que o educando buscou uma formação e por tanto deve ser uma formação voltada para seu contexto. 
Tema 4: Fatores que dificultam a ação pedagógica no contexto da educação não formal

Quadro 10 - Respostas dos sujeitos à questão: Quais as principais dificuldades encontradas na prática pedagógica no contexto da educação não formal?

\begin{tabular}{|l|l|}
\hline SUJEITOS & \multicolumn{1}{|c|}{ RESPOSTAS } \\
\hline P1 & $\begin{array}{l}\text { A principal dificuldade está relacionada na maioria das vezes ao } \\
\text { relacionamento com a equipe pedagógica do local, pois cada um tem uma } \\
\text { forma de trabalhar e isso difere de unidade para unidade. }\end{array}$ \\
\hline P2 & $\begin{array}{l}\text { Eu sinto falta de parâmetros gerais, alguma diretriz que fosse igual para } \\
\text { todo mundo, igual como é a educação formal. }\end{array}$ \\
\hline P3 & $\begin{array}{l}\text { Levando em conta o pouquíssimo tempo que venho trabalhando com a } \\
\text { educação não formal, as dificuldades que encontrei são irrelevantes perto } \\
\text { da gratificação que é trabalhar com esse tipo de educação. }\end{array}$ \\
\hline
\end{tabular}

\begin{tabular}{|l|l|}
\hline G4 & $\begin{array}{l}\text { Em sua opinião quais são as principais dificuldades encontradas } \\
\text { pelo pedagogo no contexto da educação não formal? } \\
\text { Especificamente aos profissionais que pretendem atuar no terceiro setor é } \\
\text { sempre um desafio a baixa profissionalização das instituições. }\end{array}$ \\
\hline
\end{tabular}

A análise de conteúdo das entrevistas relacionadas ao tema 4 revelou também uma distinção nas respostas de todos os sujeitos. Para a pedagoga P1 a principal dificuldade encontrada na prática pedagógica no contexto da educação não formal diz 
respeito ao relacionamento com a equipe pedagógica, pois cada um tem uma forma de trabalhar e isso acaba interferindo no resultado final.

Para a pedagoga P2 a principal dificuldade está relacionada à questão dos parâmetros gerais, pois não existem diretrizes para modalidade de educação. A pedagoga P3 relatou que as dificuldades são irrelevantes perto da gratificação que é trabalhar com esse tipo de educação. Já a gestora G4 ressaltou que a principal dificuldade está relacionada à baixa profissionalização das instituições.

Tema 5: Formação continuada no contexto da educação não formal:

Quadro 11 - Respostas dos sujeitos à questão: Você acha importante a participação em cursos de formação continuada no campo da educação não formal? Sim ou Não?

\begin{tabular}{|l|l|}
\hline SUJEITOS & \multicolumn{1}{|c|}{ RESPOSTAS } \\
\hline P1 & Sim \\
\hline P2 & Sim \\
\hline P3 & Sim \\
\hline
\end{tabular}

G4 Em sua opinião é importante a participação do pedagogo em cursos de formação continuada no campo da educação não formal? Sim.

A análise de conteúdo das entrevistas relacionadas ao tema 5 mostrou uma unanimidade de resposta sobre a participação em cursos de formação continuada no campo da educação não formal. Todos os sujeitos P1, P2, P3 e G4 disseram que é importante sim participar de cursos de formação continuada no campo da educação não formal. 
Quadro 12 - Respostas dos sujeitos à questão: Existe algum incentivo por parte da instituição onde você trabalha para participar de cursos desse tipo? Sim ou Não?

\begin{tabular}{|l|l|}
\hline SUJEITOS & \multicolumn{1}{|c|}{ RESPOSTAS } \\
\hline P1 & Sim \\
\hline P2 & Sim \\
\hline P3 & Sim \\
\hline
\end{tabular}

\begin{tabular}{|l|l|}
\hline G4 & $\begin{array}{l}\text { Existe algum incentivo por parte da instituição para que o } \\
\text { pedagogo participe de cursos desse tipo? } \\
\text { Sim. Mais do que incentivo, a instituição realiza atividades de formação } \\
\text { continuada com seus profissionais, além de supervisão especializada. }\end{array}$ \\
\hline
\end{tabular}

Seguindo a linha de análise de conteúdo das entrevistas relacionadas ao tema 5 , houve unanimidade nas respostas de todos os sujeitos. Tanto as pedagogas P1, P2 e P3 como a gestora G4 revelaram que a existe sim o incentivo por parte da instituição para que todos participem de cursos de formação no campo da educação não formal.

Quadro 13 - Respostas dos sujeitos à questão: Como os cursos de formação continuada contribuem na sua prática no contexto da educação não formal?

\begin{tabular}{|l|l|}
\hline SUJEITOS & \multicolumn{1}{|c|}{ RESPOSTAS } \\
\hline P1 & $\begin{array}{l}\text { Esses cursos contribuem porque são instrumentos de trabalho, tem que } \\
\text { fazer parte do trabalho no campo da educação não formal. }\end{array}$ \\
\hline
\end{tabular}




\begin{tabular}{|l|l|}
\hline P2 & $\begin{array}{l}\text { Contribuem para a reflexão, para a reconstrução de conceitos, de outros } \\
\text { valores, discussão das práticas, aperfeiçoamento do que é desenvolvido, } \\
\text { tudo isso é fundamental. }\end{array}$ \\
\hline P3 & $\begin{array}{l}\text { A formação continuada contribui muito para minha prática como } \\
\text { educadora. Busco estar sempre aprendendo para poder repassar esses } \\
\text { conhecimentos para meus educandos. }\end{array}$ \\
\hline
\end{tabular}

\begin{tabular}{|l|l|}
\hline G4 & $\begin{array}{l}\text { Em sua opinião de que forma os cursos de formação continuada } \\
\text { podem contribuir na prática pedagógica do pedagogo no contexto } \\
\text { da educação não formal? } \\
\text { Auxiliando-o a conhecer melhor essa área de atuação e o que é } \\
\text { necessário para atuar nela. }\end{array}$ \\
\hline
\end{tabular}

Ainda sobre a análise de conteúdo das entrevistas relacionadas ao tema 5, houve unanimidade nas respostas de todos os sujeitos, P1, P2, P3 e G4. Todos revelaram que os cursos de formação continuada contribuem de alguma forma na sua prática no contexto da educação não formal.

Quadro 14 - Respostas dos sujeitos à questão: Deseja fazer algum comentário?

\begin{tabular}{|l|l|}
\hline SUJEITOS & \multicolumn{1}{|c|}{ RESPOSTAS } \\
\hline P1 & $\begin{array}{l}\text { Com os trabalhos de pesquisa como esse, e educação não formal tende } \\
\text { a melhorar. Principalmente, no sentido de dar mais instrumentos para os } \\
\text { educadores dessa área desenvolver um trabalho mais efetivo e com } \\
\text { mais segurança na hora prática de ensinar seja qual for o conteúdo. }\end{array}$ \\
\hline
\end{tabular}




\begin{tabular}{|l|l|}
\hline P2 & $\begin{array}{l}\text { A educação não formal busca atingir o que muitas vezes a educação } \\
\text { formal não alcança daí a preocupação dessa modalidade de educação } \\
\text { dar subsídios aos jovens de ampliar seus horizontes. }\end{array}$ \\
\hline P3 & $\begin{array}{l}\text { Gostaria de agradecer pela oportunidade de participar da sua pesquisa e } \\
\text { desejar boa sorte. }\end{array}$ \\
\hline
\end{tabular}

Encerrando a análise de conteúdo das entrevistas relacionadas a todos os temas, apenas as pedagogas P1, P2 e P3 deixaram algum tipo de comentário relacionado ao conteúdo geral da entrevista. A pedagoga $\mathrm{P} 1$ ratificou a importância de trabalhos de pesquisa como esse para a melhora do campo da educação não formal. $A$ pedagoga P2 ressaltou a importância da educação não formal e sua capacidade de atingir o que muitas vezes a educação formal não alcança. A pedagoga P3 apenas agradeceu a oportunidade de participar da referida pesquisa.

\subsection{Resultado das entrevistas com as pedagogas}

As entrevistas realizadas com as pedagogas tiveram seu alicerce na análise de conteúdo, mais especificamente pela técnica de análise temática, em que foram apresentados cinco temas, todos voltados para o contexto da atuação e inserção do pedagogo nos espaços de educação não formal.

As entrevistas relacionadas à trajetória formativa do pedagogo que atua em espaços de educação não formal definido no processo de análise temática como o tema 1 , evidenciaram que todas as pedagogas não tem formação específica no campo da educação não formal, mas tiveram experiências bem diversificadas antes de começarem a trabalhar nesse contexto.

Ainda relacionado a esse tema a maioria declarou que os cursos de graduação em pedagogia não têm contribuído para a preparação dos profissionais de pedagogia 
que atuam na educação não formal, é necessário por tanto um olhar mais profundo e uma discussão mais forte da universidade em relação a essa questão.

As entrevistas relacionadas ao tema 2 sobre a atuação do pedagogo no contexto da educação não formal revelaram que a liberdade de trabalho é uma das características marcantes para quem atua em espaços de educação não formal. Porém é essa liberdade que desqualifica essa modalidade de educação, pois a falta de uma diretriz legal faz com que as atividades e as ações desenvolvidas nesses espaços não tenham tanta importância como acontece com a educação formal.

As entrevistas relacionadas ao tema três, sobre o perfil profissional do pedagogo no contexto da educação não formal, revelaram que ainda há muita divergência em garantir se existe ou não um perfil para atuar nesses espaços. Por outro lado, uma fala que parece bem freqüente nas entrevistas quando se fala em perfil se relaciona a importância do conhecimento didático e da importância de gostar de pessoas.

As entrevistas relacionadas ao tema quatro, sobre os fatores que dificultam a ação pedagógica no contexto da educação não formal, revelaram que existe certa dificuldade no relacionamento entre as equipes pedagógicas que estão inseridas nesses espaços. Outra dificuldade evidenciada se relaciona à falta diretrizes legais que norteiem o trabalho desenvolvido nos espaços de educação não formal, assim como acontece na educação formal.

As entrevistas relacionadas ao tema cinco, sobre a formação continuada no contexto da educação não formal revelaram a importância de participar de cursos de formação continuada como forma de aperfeiçoar o que é desenvolvido na prática diária nos espaços de educação não formal.

Com as entrevistas das pedagogas foi possível levantar que a educação em espaços não escolares vem crescendo e se ampliando como uma modalidade complementar da educação formal. Essa discussão se confirma na própria fala das pedagogas quando se referem à atuação, pois o pedagogo sai então do espaço escolar, que até pouco tempo, era seu espaço (restrito) de trabalho, para se inserir neste novo espaço de atuação com uma visão redefinida da atuação deste profissional. 
Com essa nova proposta e possibilidade de atuação, o fica muito evidente numa análise mais profunda é que o profissional pedagogo também se transforma, se adequando a essa nova realidade, se posicionando como um profissional capaz de caminhar junto a essas diversas transformações da sociedade.

\subsection{Resultado das entrevistas com o gestor de projetos da instituição}

A entrevista feita com a gestora também foi realizada por meio da técnica de análise temática e teve como finalidade evidenciar as percepções que ela enquanto gestora tem da atuação dos profissionais de pedagogia nos espaços de educação não formal.

Em relação ao tema um, a gestora deixou evidente que o que faz o pedagogo trabalhar com a educação não formal é a vontade de exercer práticas diferentes de educação. Isso ocorre devido ao reconhecimento das práticas educativas em todas as esferas da sociedade e pelas mesmas serem pedagógicas, tendo na contemporaneidade uma visão voltada para viabilizar $\circ$ processo de ensino aprendizagem em todo e qualquer segmento social, não se restringindo apenas à escola.

Ainda em relação a esse tema, diferente do que revelaram as pedagogas, para a gestora as técnicas aprendidas na formação do pedagogo são suficientes para dar conta do universo da educação não formal, porém evidencia que uma formação específica é sempre bem vinda. Para ela, os cursos de pedagogia contribuem sim para a preparação dos profissionais de pedagogia que atuam na educação não formal, mas é importante fortalecer essa discussão com a universidade mostrando esse setor como uma opção de atuação e o que é necessário para trabalhar nele.

Sobre o tema dois, a gestora enfatizou que trabalhar com educação não formal é enfrentar desafios, para isso é preciso conhecer as técnicas e didáticas de ensino além da realidade do educando.

Em relação ao tema três, a gestora ressaltou que é importante que o pedagogo conheça o ambiente no qual está atuando, isso faz parte do perfil. Já em relação ao 
tema quatro, a gestora evidenciou que as principais dificuldades encontradas pelo pedagogo no contexto da educação não formal se relacionam a baixa profissionalização das instituições.

Sobre o tema cinco, a gestora relatou que os cursos de formação continuada podem contribuir na prática pedagógica do pedagogo no contexto da educação não formal auxiliando-o a conhecer melhor essa área de atuação e o que é necessário para atuar nela. Ainda enfatizou que a instituição incentiva a participação e inclusive realiza atividades de formação continuada com seus profissionais, além de supervisão especializada.

A entrevista com a gestora possibilitou uma reflexão mais aprofundada sobre a atuação do pedagogo nos espaços de educação não formal, pois o leque de possibilidades de atuação que hoje se abre para esse profissional são diversos. Por outro lado, diversos também são os saberes e os conhecimentos que esse profissional precisa saber para poder atuar de forma significativa nesses espaços. 


\section{CONSIDERAÇÕES FINAIS}

Nos últimos anos, tem se tornado cada vez mais freqüente a discussão e o reconhecimento de que a educação é o principal instrumento de inserção, de participação e de ascensão dos sujeitos numa sociedade que está o tempo todo em constantes e profundas mudanças.

Diante da atual realidade em que se encontra a sociedade, a educação tem se transformado na mola mestra para enfrentar os desafios que se articulam dentro dela e em todos os seus segmentos. Desafios que são gerados especialmente pela globalização e pelo avanço tecnológico da chamada sociedade da informação.

De acordo com Delors (1998):

A educação durante toda a vida se apresenta como uma das chaves de
acesso ao século XXI. Esta noção vai mais além da distinção tradicional
entre educação básica e educação permanente. Ela responde ao
desafio de um mundo que muda rapidamente. Mas esta constatação
não é nova, uma vez que em relatórios anteriores sobre educação já se
destacava a necessidade de se voltar à escola para poder dar conta
das novidades que surgem na vida particular e na vida profissional.
Esta necessidade persiste e tem inclusive se acentuado. A única forma
de satisfazê-la é que cada um de nós aprenda a aprender. (p.19).

A educação é também a mola mestra para transformar a situação de miséria, tanto intelectual quanto econômica, política e social do povo, promovendo acesso à sociedade daqueles que são vistos como os excluídos. Possibilitando assim a transformação da sociedade numa sociedade mais justa e igualitária.

No livro "A construção social da subcidadania: para uma sociologia política da modernidade periférica, Souza (2003) apresenta uma reflexão sobre como o processo de modernização das denominadas sociedades periféricas, que no caso do Brasil levaram à produção de dois tipos de cidadãos distintos, reproduzindo de forma permanente a tão famosa desigualdade social. 
Entender que os efeitos da crise econômica globalizada e a rapidez das mudanças na era da informação levaram a questão social para o primeiro plano, e com ela o processo da exclusão social, fica fácil entender o porquê a educação também se tornou um parâmetro para o crescimento da desigualdade social. E em conseqüência como a educação não formal se expandiu e tem como principal público alvo as populações mais excluídas da sociedade atual. Isso se evidencia na infinidade de projetos sociais e atividades de educação não formal voltados a esse público.

Nesse contexto é preciso entender a educação no seu aspecto mais amplo e tal aprendizado deve começar pela maneira como entendemos a educação na sociedade atual. A educação atual não se restringe mais à educação formal e restrita as escolas, ela tem um caráter multidimensional que alcança as diversas esferas da prática social o que the confere, nos espaços diferentes da escola, um caráter não formal. Dessa forma, busca-se apontar e justificar a ampliação dos espaços de atuação profissional do pedagogo, para além do ambiente escolar e da chamada educação formal.

Essa discussão contribui para uma visão mais ampla do pedagogo no que se refere à sua inserção e ao seu trabalho no campo da educação não formal, dos saberes ou conhecimentos fundamentais que estão implicados nesse campo, e da própria formação desse profissional na perspectiva de um universo tão diversificado de atuação.

Nesse contexto, celebra-se o surgimento de novas necessidades formativas e a abertura de novos âmbitos educativos, com a conseqüente ampliação de novos papéis e funções por parte do profissional da pedagogia, na ocupação dos espaços criados pela emergência de novas demandas educativas na sociedade.

Assim, considerando dados da investigação, é possível dizer que não há dúvida de que a educação não formal na sociedade atual é uma necessidade, e com isso, novas e diversificadas possibilidades de atuação para os profissionais de pedagogia vão se consolidando para atender demandas sócio-educacionais. 
É muito comum, por exemplo, encontrar não só pedagogos, mas diversos outros profissionais inseridos em espaços de educação não formal que tem sua formação centrada no processo de aprendizagem formal e que se vêem frente aos desafios de uma área complexa e contraditória. Uma área que exige conhecimentos pertinentes e a apropriação de conceitos que extrapolam a formação convencional.

A presença de diversos profissionais, no contexto da educação não formal, é importante para a flexibilidade e a amplitude que caracterizam esse campo. Essa diversidade, que também é uma das características da educação não formal, permite o crescimento de propostas na relação entre os diferentes saberes e maneiras de fazer a educação, possibilitando a emergência de outros e muitos jeitos de organizar e vivenciar o processo educacional, para além de modelos instituídos.

Dessa forma, a formação do pedagogo rompe com um perfil profissional necessariamente atuante em contextos escolares para uma definição de uma prática pedagógica que trabalhe a formação do sujeito não só no contexto escolar. Tal perspectiva amplia suas possibilidades de atuação, exigindo uma formação no âmbito social, no contexto da educação não formal.

Por outro lado, a discussão sobre a atuação do pedagogo nos espaços de educação não formal ainda parece pouco expressiva do ponto de vista da sua real importância na sociedade atual e isso faz com que ainda haja muita fragilidade no aprofundamento de pesquisas nesta área.

A pesquisa ainda aponta para uma conflitante compreensão do termo educação não formal e sua diferenciação com a educação formal e informal. É válido ressaltar que ainda não há uma definição única e consensual de "educação não formal", estes termos ainda são objeto de diferentes interpretações entre os demais teóricos dessa área de pesquisa.

Outro aspecto que parece relevante no desenvolvimento da pesquisa: apesar de estar claro, nas Diretrizes Curriculares Nacionais, o princípio de que a prática pedagógica se expressa para além do espaço escolar, abrindo assim possibilidades de inserção para o pedagogo em diversos campos do conhecimento, a formação de 
pedagogo parece permanecer direcionada, essencialmente, para o contexto formal dos muros escolares.

Outro aspecto que merece uma reflexão: é que para alguns pedagogos a formação em Pedagogia parece não oferecer, ainda, o alicerce suficiente para quando em início do trabalho profissional, possam desenvolver práticas pedagógicas que melhor adequem seu trabalho às demandas encontradas no exercício da atuação em espaços não formais.

É provável que essa concepção seja tão somente mais uma impressão, pois o curso de pedagogia também não ensina a "ser professor" a quem quer seguir a carreira docente. O curso possibilita, sim, a base teórica que é importantíssima para tal formação, ou seja, conhecimentos teóricos fundamentais que podem auxiliar na vivência da prática do estágio do curso e posteriormente na própria vida profissional.

É por isso que não se pode desconsiderar o papel e a função social preponderante e fundamental que a educação formal tem na constituição e na formação do sujeito enquanto cidadão. O aprendizado formal é essencial na formação do ser humano e por essa razão as escolas e as universidades são as principais fontes da aquisição de conhecimento e cultura.

Nesse sentido, é válido ressaltar que as escolas e as universidades tem sua importância na sociedade porque são espaços institucionais legitimados que possibilitam não apenas o aprendizado dos conteúdos ou conhecimentos teóricos fundamentais no campo de formação de cada profissão, mas auxiliam no próprio processo de inserção profissional e social de cada ser humano.

A referida concepção tem fundamento, pois apesar de vivenciar e ter uma prática pedagógica atualmente voltada à educação não formal, minha trajetória formativa está totalmente baseada na educação formal, por isso não só defendo a importância da educação formal na vida de cada cidadão como acredito ser parte de um processo fundamental no desenvolvimento de uma sociedade mais emancipada.

É claro que o momento social atual possibilita a existência de muitos e diferentes meios e espaços para educar e para aprender, e o pedagogo tem a 
oportunidade de vivenciar essas e outras práticas pedagógicas, mas não pode esquecer que foi o processo de educação formal que contribuiu para a sua formação enquanto profissional da educação.

Logo, o propósito do referido estudo não foi questionar ou afirmar se o pedagogo deve ou não atuar em outros espaços que não seja o ambiente escolar, mas perceber que a ampliação de sua atuação é uma necessidade do mundo globalizado. É trazer a discussão o mais próximo possível da universidade e da sociedade sobre a importância do papel do pedagogo, os desafios, as dificuldades que enfrenta e as contribuições que trás da sua experiência formativa e profissional escolar para o complexo e diversificado mundo da educação não formal.

É certo que a sociedade atual demanda um profissional comprometido com os problemas da educação, crítico, com domínio de conteúdo científico, pedagógico e técnico, com compromisso ético, político e histórico e com responsabilidade social para com a educação. Apesar destas questões e de várias outras já terem sido objeto de estudo, a sua importância justifica-se na necessidade de um processo de reflexão sobre a sua ação e a sua atuação como indivíduo inserido no coletivo, no político e especialmente no âmbito social.

Diante desse quadro, é possível dizer que seja em qualquer espaço de atuação formal ou não formal o pedagogo tem como desafio constituir sua identidade não só como um profissional intelectual e cientista da educação, mas como um profissional comprometido acima de tudo com a promoção e a permanência do acesso à educação ou às "educações".

Dessa maneira, deixo também claro que não se trata de defender o Terceiro Setor, responsável por grande parte das ações e atividades de educação não formal, e nem defender a própria modalidade da educação não formal como a salvadora da educação atual. Pelo contrário, o Terceiro Setor assim como outros diversos setores da sociedade possui inúmeros problemas principalmente de ordem estrutural relacionados à idoneidade de suas estruturas legais como as ONGS. 
É claro que existem sim muitas ONGs ou instituições que realizam trabalhos inovadores no campo da educação não formal e que fazem a diferença na sociedade. Mas existem também muitas instituições que pregam a responsabilidade social como mero atrativo para o recebimento de verbas financeiras que na verdade são desviadas para outros interesses.

Por tanto, quando escolhi fazer referência a temática "O desafio do pedagogo nos espaços de educação não formal" na presente pesquisa, o objetivo era o de, especialmente, compreender a história, o discurso, a cultura, as especificidades, as mediações e as relações que essa modalidade de educação e o próprio sujeito desse contexto desenvolvem com a sociedade atual.

A realização desse trabalho trouxe significativas reflexões e conclusões a respeito do papel do pedagogo no diversificado universo educativo, pois cheguei à conclusão que para entender as práticas de educação não formal é preciso entender a educação no seu sentido mais amplo, ou seja, é preciso a compreensão que as "educações" são mútuas se complementam enquanto processos de formação humana e social. 


\section{REFERÊNCIAS BIBLIOGRÁFICAS}

AFONSO, Almerindo Janela. A crise da escola e a educação não-escolar. In: Jornal a Página da Educação, ano 11, no 10, março de 2002, p.27. Disponível em: $<$ http://www.a-pagina-da-educacao.pt/>. Acesso em: 12/10/2009.

AFONSO, Almerindo Janela. Sociologia da Educação não-escolar: reactualizar um objecto ou construir uma nova problemática? In: Esteves, J. e Stoer, S. R. (orgs). A sociologia na escola: professores, educação e desenvolvimento. Porto: Afrontamento, 1992.

AFONSO, Almerindo Janela. Os lugares da educação. In: SIMSON, O.R de M. Von PARK, M. B, FERNADES, R. S (orgs). Educação não-formal - cenários da criação. Campinas, SP: Editora da Unicamp/ Centro de Memória, 2001.

ALBURQUERQUE, Antônio Carlos Carneiro de. Terceiro setor: história e gestão das organizações. São Paulo: Summus, 2006.

BARROS, V. C; SANTOS, I. M. dos. Além dos muros da escola: a educação não formal como espaço de atuação da prática do pedagogo. Disponível em:

<http://dmd2.webfactional.com/media/anais/ALEM-DOS-MUROS-DA-ESCOLA-AEDUCACAO-NAO-FORMAL-COMO-ESPACO-DE-ATUACAO-DA-PRATICA-DO-

PEDAGOGO.pdf>. Acesso em: 02/03/2011.

BARROS, Aidil Jesus da SilveiraLEHFELD, Neide Aparecida de Souza. Fundamentos de Metodologia Científica. 2. Ed. São Paulo: Makron Books, 2000.

BRASIL. Ministério da Educação. Conselho Nacional de Educação. Conselho Pleno. Resolução CNE/CP no 5, de 13 de dezembro de 2005. Diretrizes Curriculares Nacionais para o Curso de Pedagogia. Disponível em: <http://portal.mec.gov.br/cne $>$. Acesso em: 13 out. 2009.

BRASIL. Lei de Diretrizes e Bases da Educação Nacional: Lei no 9394, de 20 de dezembro de 1996. Rio de Janeiro: Casa Editorial Pargos, 1997.

BRANDÃO, Carlos Rodrigues. O que é educação? São Paulo: Brasiliense, 1995.

CHIZOTTI, A. Pesquisas em ciências humanas e sociais. São Paulo: Cortez, 1995.

DELORS, J. Educação: um tesouro a descobrir. 2. ed. São Paulo: Cortez, 2003 
DURAN, Marília Claret Geraes \& SANTOS NETO, Elydio. Processos formativos em narrativas de educadores no campo da educação não escolar. IN: VI Encontro de Pesquisa em Educação da Região Sudeste: Política, Conhecimento e Cidadania, 2004.

FERNANDES, R. S; GARCIA. V. A. Educação não-formal: campo em formação. Disponível em: <http://revistajuridica.uniube.br/index.php/rpd/article/viewFile/94/101>. Acesso em: 08/04/2001.

FIREMAM, M. D. O trabalho do pedagogo na instituição não escolar. 2006. $116 \mathrm{f}$. Dissertação (Mestrado em Educação) - Universidade Federal de Alagoas, Maceió, 1985.

FRANCO, Maria Laura Publisi Barbosa. Análise de conteúdo. Brasília, $3^{a}$ edição: Líber Livro Editora, 2008.

GADOTTI, Moacir. A questão da educação formal/não-formal. Sion: Institut Internacional des Droits de 1ํㅡㄹ Ent, 2005.

GARCIA, V. A. O papel do social e da educação não-formal nas discussões e ações educacionais. Disponível em: <http://www.am.unisal.br/pos/strictoeducacao/pdf/mesa 8 texto valeria.pdf $>$. Acesso em: 12/03/2011.

GARCIA, V. A. A educação não-formal e a questão social. $2^{\circ}$ Seminário Nacional Estado e Políticas Sociais no Brasil (UNIOSTE). Disponível em: <http://cacphp.unioeste.br/projetos/gpps/midia/seminario2/trabalhos/educacao/medu05.pdf>.

Acesso em: 14/04/2011.

GOHN, Maria da Glória. Educação não-formal e cultura política. 4 ed. São Paulo: Cortez, 2008.

GOHN, Maria da Glória. Educação Não-formal, participação da sociedade civil e estruturas colegiadas nas escolas. Ensaio: aval. Pol. Públ. Educ. Rio de Janeiro, v. 14, n. 50, p. 27-38, jan/mar: 2006.

LIBÃNEO, José Carlos. Pedagogia e pedagogos, para quê? 4 ed. São Paulo: Cortez, 2001.

MINAYO, Maria Cecília de Souza. O desafio do conhecimento - pesquisa qualitativa em saúde. São Paulo: Hucitec, 2000.

QUINTEIRO, Eudosia Acuña. Um sensível olhar sobre o terceiro setor. (org). São Paulo: Summus, 2006. 
SOUZA, Jessé. A construção social da subcidadania: para uma Sociologia Política da modernidade periférica. Belo Horizonte: UFMG, 2003.

TRILLA, Jaume. Educação formal e não-formal: pontos e contrapontos. (org). São Paulo: Summus, 2008.

ZUCCHETT, D. T; MOURA, E. P. G. Educação não escolar e universidade: necessárias interlocuções para novas questões. Disponível em: $<$ http://www.anped.org.br/reunioes/30ra/trabalhos/GT06-3417--Int.pdf >. Acesso em: $12 / 03 / 2011$. 
ANEXOS 


\section{ANEXO 1 ROTEIRO DE ENTREVISTA PEDAGOGOS \\ PARTE I - PERFIL}

1 - Apresentação:

Nome:

Idade: Sexo:

Estado Civil:

Tem filhos? ( ) Sim ( ) Não - Moram com você? ( ) Sim ( ) Não

\section{2 - Formação:}

Instituição em que se formou:

Curso:

Ano que iniciou: Ano de Conclusão:

Fez ou faz algum curso de Pós-Graduação? ( ) Sim （ ）Não

( ) Especialização - Lato Sensu - Em que?

Instituição:

( ) Mestrado ou Doutorado - Em que?

Instituição:

\section{3 - Profissão:}

Tempo que exerce a profissão de Pedagogo:

Cargo atual que ocupa na Instituição:

Já exerceu outro cargo na instituição: ( ) Sim ( ) Não

Se sim qual?

Sempre atuou na Educação não formal: ( ) Sim ( ) Não

Se sim quanto tempo atua na Educação não formal:

Possui outro tipo de emprego: ( ) Sim ( ) Não - se sim qual? 


\section{PARTE II - ROTEIRO PARA ENTREVISTA PEDAGOGOS}

1 - Com relação à trajetória formativa do pedagogo que atua no contexto da educação não formal:

a) Como aconteceu a decisão ou a oportunidade de trabalhar com a educação não formal?

b) Você tem alguma formação específica para trabalhar no contexto da educação não formal? Qual?

c) De que forma você buscou ou garantiu a sua formação para atuar em espaços de educação não formal?

d) De que experiências anteriores você se baseia para embasar a sua prática atual?

e) Em sua opinião os cursos de graduação em pedagogia têm contribuído para a preparação dos profissionais de pedagogia que atuam na educação não formal:

( ) Sim. De que forma? 
( ) Não. Por quê?

f) Você acha importante fortalecer a discussão com a Universidade da importância da atuação de pedagogos em espaços de educação não formal?

( ) Sim. De que forma?

( ) Não. Por quê?

2 - Com relação à atuação do pedagogo no contexto da educação não-formal:

a) O que é para você trabalhar com Educação não-formal?

b) Em sua opinião, que conhecimentos são fundamentais para desenvolver um trabalho pedagógico no campo da educação não formal?

3 - Com relação ao perfil profissional do pedagogo no contexto da educação não formal:

a) Existe ou não um perfil necessário para que o pedagogo desenvolva um trabalho educativo em espaços de educação não formal? Se sim qual seria esse perfil? 


\section{4 - Com relação aos fatores que dificultam a ação pedagógica no contexto da educação não formal:}

a) Quais as principais dificuldades encontradas na prática pedagógica no contexto da educação não formal?

5-Com relação à formação continuada no contexto da educação não formal:

a) Você acha importante a participação em cursos de formação continuada no campo da educação não formal?

( ) $\operatorname{Sim}($ ) Não

b) Existe algum incentivo por parte da instituição onde você trabalha para participar de cursos desse tipo:

( ) Sim ( ) Não

c) Como os cursos de formação continuada contribuem na sua prática no contexto da educação não formal?

d) Deseja fazer algum comentário? 


\section{ANEXO 2 ROTEIRO DE ENTREVISTA GESTOR DE PROJETOS PARTE I - PERFIL}

1 - Apresentação:

Nome:

Idade:

Sexo:

Estado Civil:

Tem filhos? ( ) Sim ( ) Não

2 - Formação:

Instituição em que se formou:

Curso:

Ano que iniciou:

Ano de Conclusão:

Fez ou faz algum curso de Pós-Graduação? ( ) Sim ( ) Não

( ) Especialização - Lato Sensu - Em quê?

Instituição:

( ) Mestrado ou Doutorado - Em quê?

Instituição:

3 - Profissão:

Cargo atual que ocupa na Instituição:

Tempo que exerce o cargo na Instituição:

Já exerceu outro cargo na instituição: ( ) Sim ( ) Não

Se sim qual?

Sempre atuou na área da Educação não formal: ( ) Sim ( ) Não

Quanto tempo atua na Educação não formal:

Possui outro tipo de emprego: ( ) Sim ( ) Não - se sim qual? 
PARTE II - ROTEIRO PARA ENTREVISTA SOBRE A INSTITUIÇÃO

1) Quando e porque surgiu a Instituição? Quem a criou?

2) Qual o objetivo e qual a área de atuação da Instituição?

3) Qual a estrutura da Instituição? O que cada área faz?

4) Quantos profissionais compõe a Instituição?

5) Qual o seu público-alvo e quantas pessoas atende?

6) Quais os Projetos desenvolvidos pela Instituição? 
7) Quais as principais conquistas em termos de resultados?

8) Quais as principais dificuldades enfrentadas?

9) Quais os principais parceiros da Instituição?

10) Existem pesquisas acadêmicas ou outras pesquisa sobre a Instituição? 


\section{PARTE III- ROTEIRO DE ENTREVISTA SOBRE A ATUAÇÃO DE PEDAGOGOS NOS ESPAÇOS DE EDUCAÇÃO NÃO FORMAL}

1 - Com relação à trajetória formativa do pedagogo que atua no contexto da educação não formal:

a) Em sua opinião o que faz o pedagogo na sociedade atual decidir ou ter a oportunidade de trabalhar com a educação não formal?

b) Em sua opinião o pedagogo precisa de uma formação específica para trabalhar no contexto da educação não formal? Qual?

c) Em sua opinião o pedagogo deve buscar e garantir a sua formação para atuar em espaços de educação não formal?

d) Em sua opinião as experiências que o pedagogo traz são importantes para embasar a sua prática no contexto da educação não formal?

e) Em sua opinião os cursos de graduação em pedagogia devem contribuir para a preparação dos profissionais de pedagogia que atuam na educação não formal:

( ) Sim. De que forma?

( ) Não. Por quê? 
f) Em sua opinião é importante fortalecer a discussão com a Universidade da importância da atuação de pedagogos em espaços de educação não formal? ( ) Sim. De que forma?

( ) Não. Por quê?

2 - Com relação à atuação do pedagogo no contexto da educação não formal:

a) Em sua opinião o que significa para você trabalhar com Educação não formal?

b) Em sua opinião que conhecimentos são fundamentais para que o pedagogo possa desenvolver um trabalho pedagógico no campo da educação não formal?

2 - Com relação ao perfil profissional do pedagogo no contexto da educação não formal:

a) Em sua opinião existe ou não um perfil necessário para que o pedagogo desenvolva um trabalho educativo em espaços de educação não formal? Se sim qual seria esse perfil? 
4 - Com relação aos fatores que dificultam a ação pedagógica no contexto da educação não formal:

a) Em sua opinião quais são as principais dificuldades encontradas pelo pedagogo no contexto da educação não formal?

5-Com relação à formação continuada no contexto da educação não formal:

a) Em sua opinião é importante a participação do pedagogo em cursos de formação continuada no campo da educação não formal?

( ) $\operatorname{Sim}($ ) Não

b) Existe algum incentivo por parte da instituição para que o pedagogo participe de cursos desse tipo?

( ) Sim ( ) Não

c) Em sua opinião de que forma os cursos de formação continuada podem contribuir na prática pedagógica do pedagogo no contexto da educação não formal?

d) Deseja fazer algum comentário? 


\section{ANEXO 3 - SUJEITO P1: ENTREVISTA COM SUJEITO PEDAGOGA 1 - $P_{1}$}

\section{1 - Com relação à trajetória formativa do pedagogo que atua no contexto da educação não formal:}

a) Como aconteceu a decisão ou a oportunidade de trabalhar com a educação não formal?

Primeiro, eu não sabia nem o que era educação não-formal. Trabalhei na área financeira como auxiliar administrativo por vários anos, até que perdi o emprego. Depois de um tempo, fui contratada na própria creche onde deixava meu filho que na época tinha 2 ou 3 anos, hoje está com 23 anos. Trabalhei ali e já me encantei pelo aquele tipo de educação que não sabia que tinha essa denominação de educação formal e não-formal. Então lá, eu trabalhava com as crianças que vinham da escola e não tinham para onde ir. Meu trabalho era receber as crianças que vinham da escola $e$ encaminhá-las para várias atividades. Primeiro eu as encaminhava para o almoço, depois encaminhava para escovar os dentes, depois encaminhava para fazer a lição que elas traziam da escola, e o restante do tempo você tinha que promover alguma atividade como a produção de artesanatos etc. Com isso eu fui desenvolvendo várias coisas, até artesanato que eu não sabia fazer, não tinha habilidade nenhuma com isso, aprendi a fazer com ajuda de livros e revistas e depois no outro dia eu ensinava para elas. Até dança, que eu não sabia dançar nada, aprendi com um dos alunos de 9 anos, eu ensinava depois, peças de teatros e diversas outras atividades. Isso foi há 20 anos, foi quando eu comecei a me encantar por tudo isso. Depois disso, eu continuei sendo chamada para alguns pequenos trabalhos, fui voluntária na área da educação, depois voltei para área comercial e administrativa de novo temporariamente. Foi quando nessa época eu resolvi fazer faculdade de letras e tive a experiência de dar aula como professora de português para o ensino médio, ainda ligada a faculdade. Achei uma experiência muito diferente daquele tipo de educação que eu trabalhava na creche, não gostei. Depois disso, entre 2003 e 2005 fui estudar um curso técnico na área de alimentos chamado Processamento de Alimentos no SENAI. Estudei por 2 anos o curso 
e quando a gente estava terminando, recebemos o pessoal da prefeitura na nossa sala de aula mesmo, recrutando pessoas para trabalhar num projeto piloto chamado São Paulo é uma escola. Eles queriam duas pessoas desse curso para ensinar o processo de panificação para as crianças que o projeto ia atender. Eu achei demais, porque isso me lembrou aquele trabalho que eu tinha realizado a mais ou menos 20 anos. Aí eu me inscrevi e fui admitida para trabalhar no projeto que começou no sambódromo. No começo eu achei a coisa mais estranha e fascinante ao mesmo tempo. Estranha porque eles montavam o projeto só com o nome, não tinha nada, era um projeto de caráter eleitoreiro na verdade. Então ali no sambódromo, na área dos camarotes, lanchonetes eram desenvolvidas as oficinas. A oficina da qual eu fazia parte era a de panificação, mas tinha outras oficinas, de artes, brinquedoteca, circo, enfim tinha de tudo ali. Não havia na verdade uma organização, as crianças chegavam ali e corriam para todos os espaços. Depois de algum tempo, como as crianças ficavam um pouco livres demais, eles começaram a reorganizar. Fomos admitidos pela Anhembi turismo, ficamos contratados durante 3 meses por tempo determinado, ou seja, não era CLT e a gente nem sabia disso, pois fomos contratados assim às pressas. Nesse espaço de tempo, para não dar vínculo empregatício, algumas ONGs ( Organizações nãogovernamentais) assumiram essas oficinas. Foi quando eu comecei a me preocupar, eu gostava demais daquilo tudo, daquela movimentação e aí comecei a pensar e refletir: Como é que posso trabalhar a questão do que vem da escola e chega aqui? Como é que se conduz isso tudo? Como estávamos ligados a escola, fui percebendo que a própria escola, a prefeitura, até os diretores da escola não admitiam esse projeto, porque eles eram a favor que os professores fossem mais bem remunerados do que fazer investimento em projetos como esse. Para eles, o interessante era ter uma escola de tempo integral e não ter ONGs participando disso. Então, tivemos grandes dificuldades com isso. Nessa época, motivada por essa experiência resolvi fazer pedagogia, quando na verdade eu deveria retomar a faculdade de letras que eu havia trancado por várias questões pessoais, mas eu resolvi mesmo fazer pedagogia. Em 2005 no meio do ano, o projeto teve que mudar do sambódromo para o Clube de Regatas Tietê, pois ia começar os preparativos para o carnaval e não dava para continuar naquele espaço. Lá nós tínhamos uma estrutura melhor para desenvolver o 
projeto que estava bem montado e pronto para acontecer. O projeto estava bem bonito, inclusive temos fotos, filmagem de tudo isso, isto é, quem teve a preocupação de guardar, porque hoje esse projeto praticamente não existe. Ele se transformou num programa, mas não acontece exatamente, porque quando mudou o secretário de educação, ele cortou as verbas dos projetos e então eles não iriam mais acontecer nesses espaços grandes, locais públicos. Ficou definido que eles iriam acontecer dentro das escolas municipais. E aí foi outro problema, pois aquilo que nós estávamos sentindo de longe começamos a sentir de perto, ou seja, os diretores de escola, os professores não admitiam, mas eram obrigados a oferecer aquele tipo de atividade diferenciada dentro da escola. Enfim, foi uma época de alguns conflitos, mas de muito aprendizado acima de tudo.

b) Você tem alguma formação específica para trabalhar no contexto da educação não formal? Qual?

Bom, além da pedagogia eu tenho o curso na área de Processamento de Alimentos pelo SENAI. Aqui na Associação fui contratada para trabalhar no arco da alimentação com todos os cursos e essa formação técnica me ajudou e me ajuda muito a compreender e a sugerir algumas coisas dentro do próprio curso. A formação em pedagogia me ajuda a adequar e repassar esse conhecimento mais específico de uma forma mais didática.

c) De que forma você buscou ou garantiu a sua formação para atuar em espaços de educação não formal?

$\mathrm{Na}$ verdade, posso dizer que não foi uma coisa programada. Fiz o curso de processamento de alimentos porque sempre gostei muito dessa área, mas nunca pensei que fosse me ajudar tanto na minha atuação nos espaços e educação nãoformal como aqui na Associação. 
d) De que experiências anteriores você se baseia para embasar a sua prática atual?

Bom, do ponto de vista da qualificação profissional, foco do trabalho daqui da Associação, posso dizer que são várias experiências. Experiências de trabalhos diferentes, desde o trabalho administrativo que só numa empresa trabalhei por 11 anos até a minha experiência com o trabalho informal, pois quando fiquei desempregada, tinha que me virar, então fazia e vendia chocolates, inclusive até hoje eu tenho vontade de montar uma empresa na área de alimentos. Então, como falei essa formação e as experiências de vida, da prática diária mesmo ajudam o embasamento da minha prática atual.

e) Em sua opinião, os cursos de graduação em pedagogia têm contribuído para a preparação dos profissionais de pedagogia que atuam na educação não formal:

( ) Sim. De que forma?

( $x$ ) Não. Por quê?

Acredito que não, porque é mais teoria do que prática. Eu não tive a oportunidade de fazer um curso de magistério, não sei se o curso foi abolido ou se está tentando voltar, mas conversando com pessoas que fizeram magistério, percebo que a questão da prática era mais priorizada e o curso de pedagogia trabalha e prioriza mais as teorias. Então, eu acredito que não ajuda, o que contribui mesmo são as experiências que você vai encaixando com essas teorias. É o que você vai aprendendo durante o processo, isto é, é se inserir mesmo nesse universo e colocar a mão na massa. 
f) Você acha importante fortalecer a discussão com a Universidade da importância da atuação de pedagogos em espaços de educação não formal?

(x) Sim. De que forma?

\section{( ) Não. Por quê?}

Acho importante sim. Esse fortalecimento poderia acontecer por meio de facilitar a própria inserção do estudante de pedagogia nesse universo da educação não-formal, por meio de convênios com o Terceiro setor. Por exemplo, aqui na Associação estou trabalhando num projeto que tem convênio ou parceria com a Fundação Casa, assim as universidades poderiam fazer com quem quer se inserir no contexto da educação nãoformal. Ou seja, por meio de convênios ou parcerias, ela deveria propiciar ao aluno, ver na prática como é o trabalho dentro de uma Fundação Casa, acompanhar um educador que está lá trabalhando e até ter a oportunidade de sugerir alguma coisa. Isso seria importante, pois às vezes o educador que está lá na prática só tem uma formação de ensino médio, ele é técnico em alguma coisa. Como eu quando fiz o curso técnico em alimentos, se eu não fosse fazer o curso de pedagogia, eu só saberia provavelmente aquela técnica específica da área de alimentos. Por outro lado, eu acredito que as universidades não estão preparadas para isso, pois essa questão sempre esbarra na questão do currículo e aí, por exemplo, o estágio obrigatório que tem que ser cumprido no curso de pedagogia sempre é direcionado para a educação infantil ou ensino fundamental.

\section{2 - Com relação à atuação do pedagogo no contexto da educação não formal:}

a) O que é para você trabalhar com Educação não formal?

Trabalhar com a educação não-formal significa liberdade. Acho que você tem uma liberdade maior para desenvolver seu trabalho. Por exemplo, aqui no trabalho da Associação com a Fundação Casa, você recebe um plano de curso que é flexível, ou seja, você pode adequar aquele da melhor forma ou digamos assim do seu jeito. Se você já tem experiências de outros trabalhos, consegue desenvolver aquele conteúdo 
de uma forma mais livre. Então, é a primeira coisa que me vem à cabeça quando penso em educação não-formal, liberdade de atuação e isso eu acho positivo.

b) Em sua opinião, que conhecimentos são fundamentais para desenvolver um trabalho pedagógico no campo da educação não formal?

Desde a minha experiência na época do projeto São Paulo é uma escola que eu venho pensando sobre isso, e cheguei à conclusão que o fundamental além de você ter o domínio do conteúdo, é você utilizar instrumentos de trabalho, como a didática, principalmente quando se trabalha com a formação de educadores nessa área. Como eu atuei como coordenadora nesse projeto, eu percebi que tinha alguns educadores que entendiam perfeitamente da profissão deles, mas tinham dificuldade de repassar esse conhecimento. Então, eu comecei a direcioná-los, como se fosse um diretor mesmo, olha hoje ou durante a semana você vai trabalhar esse plano de aula dessa forma, ou seja, dar instrumentos como orientação prática e didática para que ele desenvolva seu trabalho com mais eficiência etc.

\section{3 - Com relação ao perfil profissional do pedagogo no contexto da educação não formal:}

a) Existe ou não um perfil necessário para que o pedagogo desenvolva um trabalho educativo em espaços de educação não formal? Se sim qual seria esse perfil?

Eu acredito que existe sim um perfil. Não são todas as pessoas que vão trabalhar com educação e dá certo. É preciso em primeiro lugar gostar de trabalhar com gente, porque você vai estar formando pessoas, seja em qual área for, seja criança, seja adolescente ou adulto. Em segundo lugar é preciso saber ouvir, pois independente do curso, o aluno ou educando traz um conhecimento, ele não é uma cabeça vazia, ele vê de um lugar, ele traz uma cultura e isso tem que ser respeitado. 


\section{4 - Com relação aos fatores que dificultam a ação pedagógica no contexto da educação não formal:}
a) Quais as principais dificuldades encontradas na prática pedagógica no contexto da educação não formal?

A principal dificuldade é você ser um corpo estranho naquele lugar e o problema na maioria das vezes não está relacionado aquele grupo de alunos, mas a equipe pedagógica daquele local. Muitas vezes, você tem uma forma de trabalhar e isso difere de unidade para unidade. Por exemplo, na época do projeto São Paulo é uma escola, em que o projeto mudou para dentro das escolas municipais, eu ia a várias escolas e cada uma tinha uma forma diferente. Numa escola você era bem recebida, te davam espaço para trabalhar, em outra você não era bem recebida. Enfim, trabalhar num espaço que não é o seu já é difícil, imagina não se sentir pertencente daquele lugar especialmente por não ter o apoio da equipe pedagógica.

\section{5-Com relação à formação continuada no contexto da educação não formal:}

a) Você acha importante a participação em cursos de formação continuada no campo da educação não formal?

(x) $\operatorname{Sim}($ ) Não

b) Existe algum incentivo por parte da instituição onde você trabalha para participar de cursos desse tipo:

(x) $\operatorname{Sim}($ ) Não

c) Como os cursos de formação continuada contribuem na sua prática no contexto da educação não formal?

Esses cursos contribuem porque são instrumentos de trabalho, tem que fazer parte do trabalho no campo da educação não-formal. Acredito que pela falta de tempo não aconteçam mais cursos assim, mas na verdade a gente tem que buscar dentro do nosso tempo, de forma pessoal. Por exemplo, agora ultimamente fui convidada para 
ministrar um curso de jardinagem. Aí eu fiquei pensando, bom eu não tenho curso disso, mas tenho experiências pessoais que podem me ajudar, então dentro do curso de jardinagem o que seria interessante ensinar para o público que tenho lá na cidade de Itaquá. Aí é que entra o lado positivo da educação não-formal, como o plano de curso é flexível, permite que eu vá adequando o conteúdo de acordo com as necessidades dos alunos. Então, eu vou desenvolver esse trabalho porque vejo que há possibilidade, é minha experiência pessoal que eu quero contribuir com eles, não que eu me sinta preparada para isso, é um desafio.

d) Deseja fazer algum comentário?

Eu acredito que a educação não-formal daqui para frente, com os trabalhos de pesquisa como esse, tende a melhorar. Principalmente, no sentido de dar mais instrumentos para os educadores dessa área desenvolver um trabalho mais efetivo e com mais segurança na hora prática de ensinar seja qual for o conteúdo. 


\section{ANEXO 4 - SUJEITO P2: \\ ENTREVISTA COM SUJEITO PEDAGOGA 2 - $\mathbf{P}_{2}$}

1 - Com relação à trajetória formativa do pedagogo que atua no contexto da educação não formal:

a) Como aconteceu a decisão ou a oportunidade de trabalhar com a educação não formal?

A minha inserção no universo da educação não-formal foi meio ao acaso. Na verdade, eu sou formada em Recursos humanos primeiramente, trabalhava nessa área e eu pensei na pedagogia como complemento da profissão que eu escolhi anteriormente. Só que assim que eu ingressei na faculdade, fui procurar um estágio na área de treinamento e desenvolvimento de pessoas, mais foi complicado conseguir uma colocação, porque além de ser uma faculdade tecnológica, era um curso relativamente novo no Brasil. Então comecei a procurar estágio em todas as áreas dentro da pedagogia, até que eu participei do processo seletivo aqui na Associação, fui selecionada e então conheci o projeto. Quando eles me contaram como funcionava o projeto, qual era o trabalho realizado aqui pela entidade, então eu já me encantei nesse momento. Ingressei, consegui o estágio e estou aqui até hoje. Na verdade, foi uma oportunidade que surgiu e eu não larguei mais.

b) Você tem alguma formação específica para trabalhar no contexto da educação não formal? Qual?

A minha formação em recursos humanos e assim com a formação em pedagogia me auxilia muito, porque a gente trabalha com qualificação profissional. Por enquanto eu não tenho especialização, acabei de iniciar um que é para tecnologia da educação. 
c) De que forma você buscou ou garantiu a sua formação para atuar em espaços de educação não formal?

$\mathrm{Na}$ verdade, eu não busquei tudo aconteceu meio ao acaso. Mas agora com a formação em pedagogia e com minha inserção nesse contexto da educação não-formal estou buscando algumas especializações e tentando cada vez mais me adequar a esse universo.

d) De que experiências anteriores você se baseia para embasar a sua prática atual?

Baseio-me nas experiências de vida, além das práticas pedagógicas de ensino. São experiências pessoais que a gente vai vivenciando e que contribuem na formação do aluno, pois temos que desenvolver nosso aluno ao empreendedorismo, à busca pela qualificação mesmo.

e) Em sua opinião, os cursos de graduação em pedagogia têm contribuído para a preparação dos profissionais de pedagogia que atuam na educação não formal:

( ) Sim. De que forma?

(x ) Não. Por quê?

Eu acredito que não contribui também. Na verdade é assim, pelo menos na instituição em que eu me formei, o foco principal era educação infantil e a maioria das alunas já trabalhavam nessa área. Então, por exemplo, como o curso de pedagogia não me deu preparação, o que tento fazer é adequar o conhecimento e a teoria a nossa realidade aqui. Nem mesmo as publicações de revistas do setor são focadas nesse universo, a grande maioria é voltada para a educação formal, e aí entra a educação infantil e o ensino fundamental, isto é, não abrange outras áreas como EJA, educação para qualificação profissional etc. 
f) Você acha importante fortalecer a discussão com a Universidade da importância da atuação de pedagogos em espaços de educação não formal?

(x) Sim. De que forma?

\section{( ) Não. Por quê?}

Eu acho importante sim. Acho que é fundamental inclusive uma revisão em nível de currículo para a formação de novos profissionais. Eu acredito que não só o pedagogo, mas qualquer profissional de licenciatura não sai preparado para a realidade da sua profissão, ou seja, para a realidade que ele vai enfrentar no seu dia-dia. Ainda estamos muito protegidos pelas teorias, pelos conteúdos mais formais e por isso não estamos preparados para essa realidade, principalmente nós que atuamos na área da educação não-formal. Assim, além de você não sair preparado para a sua prática diária, ainda sai fragilizado por ter que adaptar aquele conteúdo para a sua realidade que é outra. Por tanto, seria primordial que a universidade repensasse a questão do currículo, pois eu acho difícil alguém que se forme em pedagogia, se ela nunca atuou no Terceiro setor ou com essa modalidade de educação não-formal, vai acabar sendo direcionado a trabalhar na educação infantil ou no ensino fundamental.

\section{2 - Com relação à atuação do pedagogo no contexto da educação não formal:}

a) O que é para você trabalhar com Educação não formal?

È ai que eu me pego naquele dilema sabe, até onde nós não somos formais? Porque é assim, a gente desenvolve o plano de curso, agente desenvolve plano de aula, agente trabalha instrumentalizado nesse sentido, mas ao mesmo tempo nós não temos um direcionamento, como a lei de diretrizes e bases da educação, que nos dê um direcionamento que me diga, olha você tem que ir por aqui ou por ali, ou então isso tem que ser cumprido na sua atuação. Enfim, sem falar naquele meio termo, nós temos a liberdade de decidir o que o nosso aluno vai estudar, mas ao mesmo tempo eu sinto falta do que realmente seria necessário para esse aluno num todo. Por exemplo, nas várias entidades nós vemos muita diferença nos projetos, uns tem mais organização 
outros não, você que já trabalhou no Terceiro setor acredito também que já tenha visto isso. Às vezes, acontece de estarmos atuando no mesmo projeto e cada um está trabalhando de uma forma diferente, tudo porque não temos na área da educação nãoformal uma legislação específica. Uma legislação que dê uma direção a todos, cada um acaba fazendo do seu jeito, de acordo com seu estatuto ou com o que determinado programa ou projeto pede, mas até aí fica cada um por si.

b) Em sua opinião, que conhecimentos são fundamentais para desenvolver um trabalho pedagógico no campo da educação não formal?

Eu acredito que primeiro, ele tem que saber o que é a educação e qual é o papel dele aí, porque muitos profissionais que nós temos realmente são profissionais com formação técnica. Por exemplo, num curso de colocação de azulejos, dificilmente vamos encontrar um profissional da educação que também tenha essa habilidade, ou seja, essa formação técnica. Então, ele precisa conhecer e entender qual o papel dele nesse universo, ter algumas práticas, noções de metodologias, de didática para poder trabalhar com esse aluno.

\section{3 - Com relação ao perfil profissional do pedagogo no contexto da educação não formal:}

a) Existe ou não um perfil necessário para que o pedagogo desenvolva um trabalho educativo em espaços de educação não formal? Se sim qual seria esse perfil?

Eu acho que depende. Depende justamente por essa ainda indefinição da atuação da educação não-formal. Tem o que a gente considera ideal, mas é muito relativo, nem todas as entidades trabalham com pedagogos por exemplo. Na verdade, esse perfil está mais relacionado com o que a instituição desenvolve, porque é aí que você tem que se adequar. Agora falando com uma visão de projeto, cada projeto você vai atuar de uma forma diferente, por causa das suas especificidades. Às vezes, você tem que ser polivalente, pois além de se preocupar com a área pedagógica, da educação, você precisa também se preocupar com a área administrativa, em procurar um espaço, em 
como recrutar os jovens, em pensar onde comprar um lanche de acordo com averba que você tem. Enfim, são várias coisas que vai depender do projeto, da entidade etc.

\section{4 - Com relação aos fatores que dificultam a ação pedagógica no contexto da educação não formal:}

a) Quais as principais dificuldades encontradas na prática pedagógica no contexto da educação não formal?

Eu sinto falta de parâmetros gerais. A minha atuação aqui é mais voltada para o desenvolvimento de planos de cursos, apostilas, e o que sinto falta são de parâmetros gerais, alguma diretriz que fosse igual para todo mundo, igual como é a educação nãoformal.

\section{5-Com relação à formação continuada no contexto da educação não formal:}

a) Você acha importante a participação em cursos de formação continuada no campo da educação não formal?

( $x) \operatorname{Sim}($ ) Não

b) Existe algum incentivo por parte da instituição onde você trabalha para participar de cursos desse tipo:

( $x$ ) $\operatorname{Sim}($ ) Não

c) Como os cursos de formação continuada contribuem na sua prática no contexto da educação não formal?

Contribuem para a reflexão, para a reconstrução de conceitos, de outros valores, discussão das práticas, aperfeiçoamento do que é desenvolvido, tudo isso é fundamental. 
d) Deseja fazer algum comentário?

$\mathrm{Na}$ verdade, a gente busca atingir o que muitas vezes a educação formal não alcança. Então, por exemplo, o perfil dos nossos alunos, de 60 a 70\% dentro da Fundação Casa, não tem o fundamental completo, muitos não lêem, nem escrevem, muitos não terminaram os estudos, são de famílias de baixa renda, com renda de um salário mínimo para 5 ou 6 pessoas. Então, realmente buscamos atingir esses jovens para mostrar um mundo que não se resume a sua comunidade. Teve um projeto que realizamos um tempo desses, não lembro o ano, que levamos os alunos para conhecerem a Av. Paulista aqui em São Paulo, pois eles nunca haviam saído da comunidade. Esse foi um momento de ampliar o horizonte deles, de mostrar a eles que existem outras possibilidades, que eles podem também ser empreendedores ali dentro da comunidade mesmo. 


\section{ANEXO 5 - SUJEITO P3: \\ ENTREVISTA COM SUJEITO PEDAGOGA $3-\mathrm{P}_{3}$}

1 - Com relação à trajetória formativa do pedagogo que atua no contexto da educação não formal:

a) Como aconteceu a decisão ou a oportunidade de trabalhar com a educação não formal?

Não foi uma decisão e sim uma oportunidade que surgiu, e eu como pedagoga recémformada com muita vontade de trabalhar aceitei, o que para mim está sendo um desafio do qual eu estou muito orgulhosa.

b) Você tem alguma formação específica para trabalhar no contexto da educação não formal? Qual?

Não, sou formada apenas em pedagogia.

c) De que forma você buscou ou garantiu a sua formação para atuar em espaços de educação não formal?

Eu diria que ainda estou buscando. Sou uma educadora com sede de aprender, por isso busco aprender sempre e a Associação Horizontes, a instituição para qual eu trabalho, oferece aos seus educadores formação contínua, por meio de cursos, palestras, treinamentos, enfim, só não se capacita quem não quer mesmo. 
d) De que experiências anteriores você se baseia para embasar a sua prática atual?

$\mathrm{Na}$ verdade eu não tenho experiências anteriores, mas procuro estar sempre aberta para novos conhecimentos e a experiência virá com o tempo, com a prática diária eu acredito.

e) Em sua opinião os cursos de graduação em pedagogia têm contribuído para a preparação dos profissionais de pedagogia que atuam na educação não formal:

(x) Sim. De que forma?

( ) Não. Por quê?

Quando se fala em educação, independente de ser educação formal ou educação nãoformal, a qualidade deve vir sempre em primeiro lugar. O profissional graduado em pedagogia tem uma visão mais ampla da educação em geral. Acredito que o pedagogo consegue organizar as formas de transmissão de conhecimento de maneira mais clara, focando sempre o aprendizado.

f) Você acha importante fortalecer a discussão com a Universidade da importância da atuação de pedagogos em espaços de educação não formal?

(x) Sim. De que forma?

( ) Não. Por quê?

Há pouco tempo a atuação do pedagogo estava centrada no contexto da educação formal, hoje o pedagogo encontra-se inserido num novo espaço de atuação. É importante que haja discussão com a Universidade, pois com essa nova perspectiva cada vez mais pedagogos estão inseridos na educação não-formal. 


\section{2 - Com relação à atuação do pedagogo no contexto da educação não formal:}

a) O que é para você trabalhar com Educação não formal?

Eu estou começando a minha vida profissional como educadora, e trabalhar na educação não-formal para mim está sendo um grande aprendizado, são experiências que vou levar para o resto da minha vida e com certeza para outras oportunidades de trabalho e de atuação.

b) Em sua opinião, que conhecimentos são fundamentais para desenvolver um trabalho pedagógico no campo da educação não formal?

Acredito que os conhecimentos fundamentais são: flexibilidade, motivação e principalmente gostar daquilo que faz.

3 - Com relação ao perfil profissional do pedagogo no contexto da educação não formal:

a) Existe ou não um perfil necessário para que o pedagogo desenvolva um trabalho educativo em espaços de educação não formal? Se sim qual seria esse perfil?

Um perfil não, mas para que haja o desenvolvimento de um trabalho efetivo e de qualidade, é fundamental que o profissional goste daquilo que faz, e que principalmente esteja aberto para buscar novos conhecimentos. 


\section{4 - Com relação aos fatores que dificultam a ação pedagógica no contexto da educação não formal:}

a) Quais as principais dificuldades encontradas na prática pedagógica no contexto da educação não formal?

Eu ainda estou iniciando a minha caminhada nessa área, mas o pouquíssimo tempo que venho trabalhando com a educação não-formal, as dificuldades que encontrei são irrelevantes perto da gratificação que é trabalhar com esse tipo de educação.

5 - Com relação à formação continuada no contexto da educação não formal:

a) Você acha importante a participação em cursos de formação continuada no campo da educação não formal?

( x ) $\operatorname{Sim}($ ) Não

c) Existe algum incentivo por parte da instituição onde você trabalha para participar de cursos desse tipo:

(x) $\operatorname{Sim}($ ) Não

d) Como os cursos de formação continuada contribuem na sua prática no contexto da educação não formal?

A formação continuada contribui muito para minha prática como educadora. Busco estar sempre aprendendo para poder repassar esses conhecimentos para meus educandos.

e) Deseja fazer algum comentário?

Gostaria de agradecer pela oportunidade de participar da sua pesquisa e desejar boa sorte. 


\section{ANEXO 6 - SUJEITO G4: \\ ENTREVISTA COM SUJEITO GESTOR DE PROJETOS 4 - G4}

\section{PARTE II - ROTEIRO PARA ENTREVISTA SOBRE A INSTITUIÇÃO}

\section{1) Quando e porque surgiu a Instituição? Quem a criou?}

A Horizontes foi criada em 2004 por profissionais que aproveitaram suas diferentes experiências para realizar projetos sociais que, efetivamente, resultassem em alguma transformação na vida de seus beneficiários, especialmente no que diz respeito à inserção produtiva e social.

\section{2) Qual o objetivo e qual a área de atuação da Instituição?}

A Horizontes atua na área da educação e tem por missão promover a sustentabilidade, a cidadania, a inclusão social e a geração de trabalho e renda por meio da educação.

\section{3) Qual a estrutura da Instituição? O que cada área faz?}

$\mathrm{O}$ órgão máximo da $\mathrm{AH}$ é sua Assembléia Geral. Abaixo dela estão o Conselho Consultivo, que colabora, em caráter consultivo, na gestão da entidade, o Conselho Fiscal, que fiscaliza a administração contábil-financeira da $\mathrm{AH}$ e o Conselho Diretor, que traça as diretrizes políticas e técnicas da Associação e é composto por Presidente, Primeiro Vice-Presidente e Vice-Presidente Administrativo-Financeiro. Abaixo dessas vice-presidências estão as áreas de apoio e operacional que trabalham para a efetiva execução dos projetos que a $\mathrm{AH}$ realiza.

\section{4) Quantos profissionais compõe a Instituição?}

Atualmente, 193 pessoas fazem parte do quadro de profissionais da $\mathrm{AH}$.

\section{5) Qual o seu público-alvo e quantas pessoas atende?}


Atendemos, prioritariamente, jovens e adultos em situação de vulnerabilidade social. Em seus 7 anos de existência, a entidade atendeu cerca de 107.000 pessoas e, atualmente, encontram-se em execução 6 projetos que qualificação que beneficiam cerca de 20.000 educandos.

\section{6) Quais os Projetos desenvolvidos pela Instituição?}

Projetos de qualificação profissional básica;

Projetos de Direitos Humanos;

Projetos de Educação Ambiental;

Projetos culturais;

Projetos Educacionais.

\section{7) Quais as principais conquistas em termos de resultados?}

Qualificação de mais de 107.000 pessoas e inserção no mercado de trabalho e em atividades produtivas de mais 22.000 delas.

\section{8) Quais as principais dificuldades enfrentadas?}

A necessidade de se diferenciar frente a tantas instituições pouco profissionais e sob suspeita de práticas pouco éticas. Para isso buscamos, além da execução de projetos com seriedade e profissionalismo, a certificação da entidade segundo normas internacionais de boas práticas de gestão.

\section{9) Quais os principais parceiros da Instituição?}

Universidade e organizações públicas e privadas que invistam no desenvolvimento dos projetos da entidade.

\section{0) Existem pesquisas acadêmicas ou outras pesquisa sobre a Instituição?}

Existe uma pesquisa acadêmica que considerou o impacto social de um dos projetos realizado pela $\mathrm{AH}$, além de alguns TCCs. 


\section{PARTE III- ROTEIRO DE ENTREVISTA SOBRE A ATUAÇÃO DE PEDAGOGOS NOS ESPAÇOS DE EDUCAÇÃO NÃO FORMAL}

\section{1 - Com relação à trajetória formativa do pedagogo que atua no contexto da educação não formal:}

a) Em sua opinião o que faz o pedagogo na sociedade atual decidir ou ter a oportunidade de trabalhar com a educação não formal?

Além do interesse em exercer práticas diferentes de educação, que às vezes não são possíveis em algumas instituições de ensino formal, em particular na maioria das instituições públicas, a vontade de educar para que o educando ganhe autonomia e possa se inserir socialmente.

b) Em sua opinião o pedagogo precisa de uma formação específica para trabalhar no contexto da educação não formal? Qual?

Penso que as técnicas aprendidas na formação do pedagogo são suficientes. Mas para que elas funcionem é necessária a vontade de fazer da educação uma atividade prazerosa que contribua, necessariamente, para a autonomia do educando.

c) Em sua opinião o pedagogo deve buscar e garantir a sua formação para atuar em espaços de educação não formal?

A formação específica na área da educação é sempre bem vinda.

d) Em sua opinião as experiências que o pedagogo traz são importantes para embasar a sua prática no contexto da educação não formal?

Sim, as experiências sempre contribuem para o desempenho de sua função.

e) Em sua opinião os cursos de graduação em pedagogia devem contribuir para a preparação dos profissionais de pedagogia que atuam na educação não formal:

(x) Sim. De que forma?

Penso que já contribuem. Mas sempre há espaço para fortalecer essa atividade.

( ) Não. Por quê? 
f) Em sua opinião é importante fortalecer a discussão com a Universidade da importância da atuação de pedagogos em espaços de educação não formal? (x) Sim. De que forma?

Mostrando esse setor como uma opção de atuação e o que é necessário para trabalhar nele.

( ) Não. Por quê?

2 - Com relação à atuação do pedagogo no contexto da educação não-formal:

a) Em sua opinião o que significa para você trabalhar com Educação não formal? Enfrentar desafios e ser criativo para tornar o aprendizado prazeroso.

b) Em sua opinião que conhecimentos são fundamentais para que o pedagogo possa desenvolver um trabalho pedagógico no campo da educação não formal?

Conhecer as técnicas e didáticas de ensino é sempre importante, além da realidade do educando.

\section{3 - Com relação ao perfil profissional do pedagogo no contexto da educação não- formal:}

a) Em sua opinião existe ou não um perfil necessário para que o pedagogo desenvolva um trabalho educativo em espaços de educação não formal? Se sim qual seria esse perfil?

Penso que a consciência de que o educando buscou uma formação, por livre vontade, e de que sua permanência na instituição dependerá da contribuição dessa formação para sua vida e do quão prazeroso é esse processo é fundamental a todo o profissional que pretende atuar em espaços de educação não-formal. 


\section{4 - Com relação aos fatores que dificultam a ação pedagógica no contexto da educação não formal:}

a) Em sua opinião quais são as principais dificuldades encontradas pelo pedagogo no contexto da educação não formal?

Especificamente aos profissionais que pretendem atuar no terceiro setor é sempre um desafio a baixa profissionalização das instituições.

\section{5-Com relação à formação continuada no contexto da educação não formal:}

a) Em sua opinião é importante a participação do pedagogo em cursos de formação continuada no campo da educação não formal?

( $x) \operatorname{Sim}($ ) Não

b) Existe algum incentivo por parte da instituição para que o pedagogo participe de cursos desse tipo?

( $x$ ) $\operatorname{Sim}($ ) Não

Mais do que incentivo, a instituição realiza atividades de formação continuada com seus profissionais, além de supervisão especializada.

c) Em sua opinião de que forma os cursos de formação continuada podem contribuir na prática pedagógica do pedagogo no contexto da educação não formal?

Auxiliando-o a conhecer melhor essa área de atuação e o que é necessário para atuar nela.

d) Deseja fazer algum comentário? 